Prepared in cooperation with the New Mexico Water Resources Research Institute

\title{
Assessment of Statewide Annual Streamflow in New Mexico, 1985-2013
}

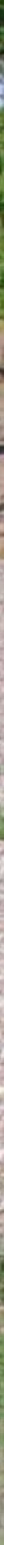

Scientific Investigations Report 2015-5082

U.S. Department of the Interior

U.S. Geological Survey 
Cover.

Photograph showing the Gila River from Old Iron Bridge, located about 1.6 miles south of Cliff, New Mexico. The Big Burro Mountains can be seen in the background. 


\section{Assessment of Statewide Annual Streamflow in New Mexico, 1985-2013}

By Joseph A. Affinati and Nathan C. Myers

Prepared in cooperation with the New Mexico Water Resources Research Institute

Scientific Investigations Report 2015-5082 


\title{
U.S. Department of the Interior SALLY JEWELL, Secretary
}

\section{U.S. Geological Survey \\ Suzette M. Kimball, Acting Director}

\author{
U.S. Geological Survey, Reston, Virginia: 2015
}

For more information on the USGS - the Federal source for science about the Earth, its natural and living resources, natural hazards, and the environment—visit http://www.usgs.gov or call 1-888-ASK-USGS.

For an overview of USGS information products, including maps, imagery, and publications, visit http://www.usgs.gov/pubprod/.

Any use of trade, firm, or product names is for descriptive purposes only and does not imply endorsement by the U.S. Government.

Although this information product, for the most part, is in the public domain, it also may contain copyrighted materials as noted in the text. Permission to reproduce copyrighted items must be secured from the copyright owner.

The New Mexico Water Resources Research Institute and the U.S. Geological Survey make no warranties, express or implied, as to the use of the information obtained from this data product. All information included with this product is provided without warranty or any representation of accuracy and timeliness of completeness. Users should be aware that changes may have occurred since this dataset was collected and that some parts of this dataset may no longer represent actual conditions. This information may be updated without notification. Users should not use these data for critical applications without a full awareness of their limitations. This product is for informational purposes only and may not be suitable for legal, engineering, or surveying purposes. The New Mexico Water Resources Research Institute and the U.S. Geological Survey shall not be liable for any activity involving these data, installation, fitness of the data for a particular purpose, their use, or analyses results.

Suggested citation:

Affinati, J.A., and Myers, N.C., 2015, Assessment of statewide annual streamflow in New Mexico, 1985-2013:

U.S. Geological Survey Scientific Investigations Report 2015-5082, 65 p., http://dx.doi.org/10.3133/sir20155082.

ISSN 2328-0328 (online) 


\section{Contents}

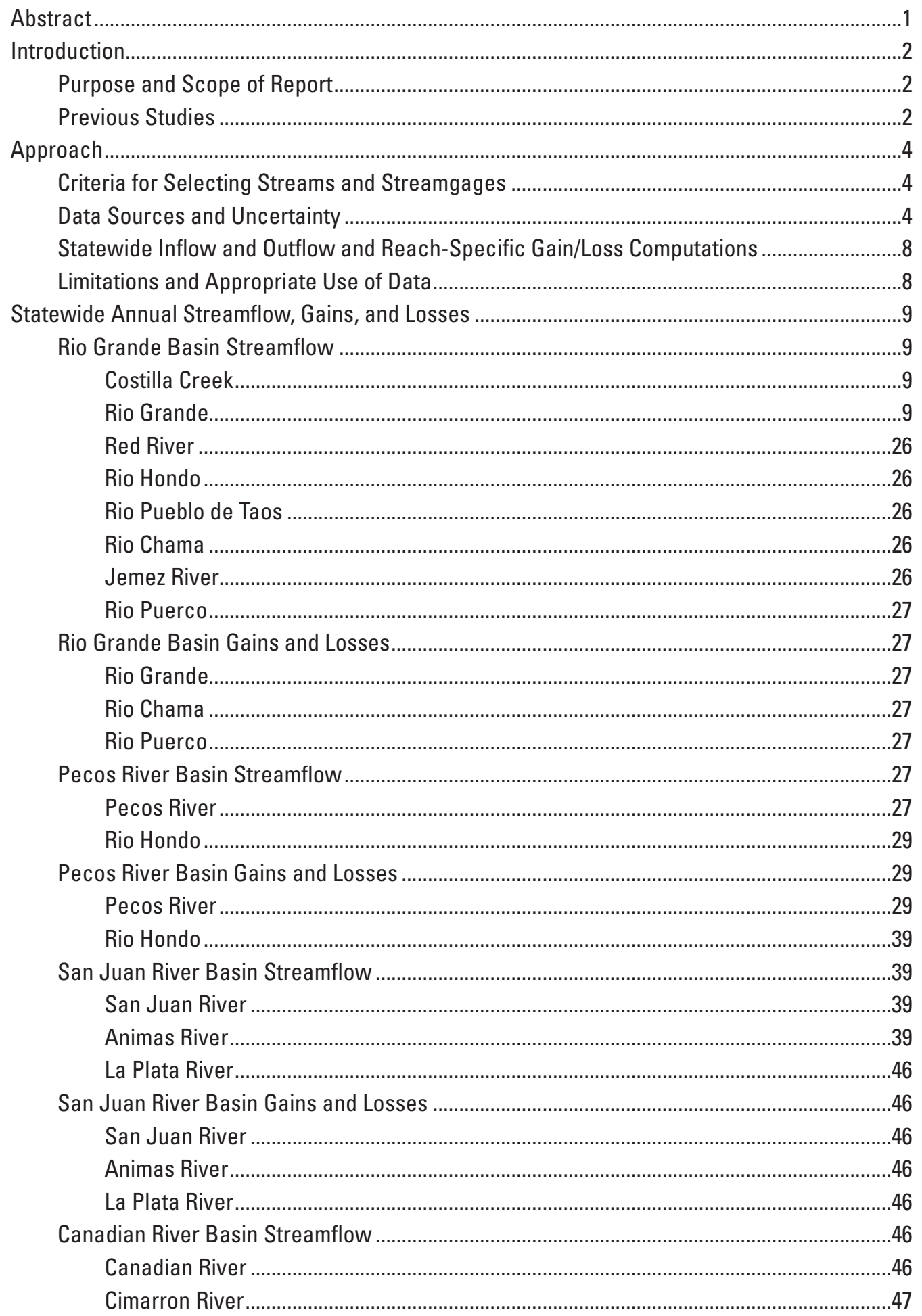


Canadian River Basin Gains and Losses ...............................................................................

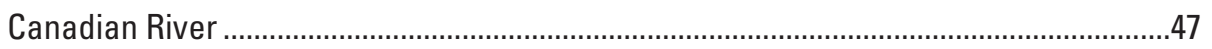

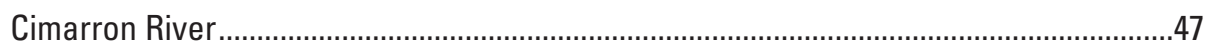

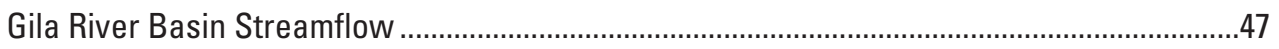

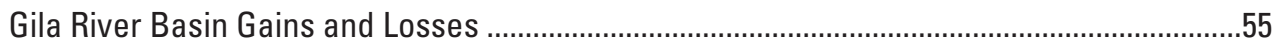

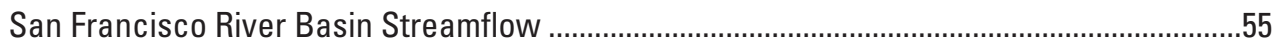

San Francisco River Basin Gains and Losses.......................................................................5

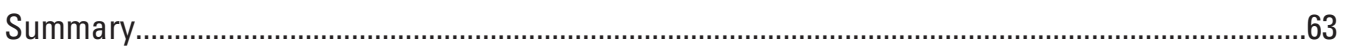

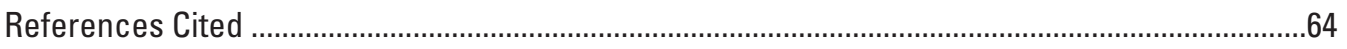

Appendixes [available at http://pubs.usgs.gov/sir/2015/5082/]

1. Accuracy ratings for selected streamgages in the six-basin study area, New Mexico and parts of bordering States and Mexico, water years 1985-2013.

2. Monthly streamflow at selected Costilla Creek and tributary streamgages in the sixbasin study area, New Mexico and parts of bordering States and Mexico, water years 1985-2013.

3. Monthly streamflow at selected Rio Grande streamgages in the six-basin study area, New Mexico and parts of bordering States and Mexico, water years 1985-2013.

4. Monthly streamflow at selected Rio Grande tributary streamgages in the six-basin study area, New Mexico and parts of bordering States and Mexico, water years 1985-2013.

5. Monthly streamflow at selected Pecos River Basin streamgages in the six-basin study area, New Mexico and parts of bordering States and Mexico, water years 1985-2013.

6. Monthly streamflow at selected San Juan River Basin streamgages in the six-basin study area, New Mexico and parts of bordering States and Mexico, water years 1985-2013.

7. Monthly streamflow at selected Canadian River Basin streamgages in the six-basin study area, New Mexico and parts of bordering States and Mexico, water years 1985-2013.

8. Monthly streamflow at selected Gila River Basin streamgages in the six-basin study area, New Mexico and parts of bordering States and Mexico, water years 1985-2013.

9. Monthly streamflow at selected San Francisco River Basin streamgages in the sixbasin study area, New Mexico and parts of bordering States and Mexico, water years 1985-2013.

\section{Figures}

1. Map showing river basins, rivers, and streamgages selected for study of annual streamflow in the six-basin study area, New Mexico and parts of bordering States and Mexico, water years 1985-2013..

2. Map showing the Rio Grande Basin, streams, stream reaches, and streamgages upstream from the Rio Grande at El Paso, Texas (08364000), streamgage in the six-basin study area, New Mexico and parts of bordering States and Mexico

3. Graphs showing annual streamflow, departure of annual streamflow from mean annual streamflow, and annual difference in streamflow for streams in the Rio Grande Basin in the six-basin study area, New Mexico and parts of bordering States and Mexico, water years 1985-2013. 
4. Map showing the Pecos River Basin, streams, stream reaches, and streamgages upstream from the Pecos River at Red Bluff, New Mexico (08407500), streamgage in the six-basin study area, New Mexico and parts of bordering States and Mexico

5. Graphs showing annual streamflow, departure of annual streamflow from mean annual streamflow, and annual difference in streamflow for streams in the Pecos River Basin in the six-basin study area, New Mexico and parts of bordering States and Mexico, water years 1985-2013.

6. Map showing the San Juan River Basin, streams, stream reaches, and streamgages upstream from the San Juan River at Four Corners, Colorado (09371010), streamgage in the six-basin study area, New Mexico and parts of bordering States and Mexico...

7. Graphs showing annual streamflow, departure from mean annual streamflow, and annual difference in streamflow for streams in the San Juan River Basin in the six-basin study area, New Mexico and parts of bordering States and Mexico, water years 1985-2013.

8. Map showing the Canadian River Basin, streams, stream reaches, and streamgages upstream from the Canadian River at the New Mexico-Texas State line in the six-basin study area, New Mexico and parts of bordering States and Mexico..

9. Graphs showing annual streamflow, departure from mean annual streamflow, and annual difference in streamflow for streams in the Canadian River Basin in the six-basin study area, New Mexico and parts of bordering States and Mexico, water years 1985-2013.

10. Map showing the Gila and San Francisco River Basins, streams, stream reaches, and streamgages upstream from the confluence of the Gila and San Francisco Rivers in the six-basin study area, New Mexico and parts of bordering States and Mexico..

11. Graphs showing annual streamflow, departure from mean annual streamflow, and annual difference in streamflow for streams in the Gila River Basin in the six-basin study area, New Mexico and parts of bordering States and Mexico, water years 1985-2013

12. Graphs showing annual streamflow, departure from mean annual streamflow, and annual difference in streamflow for streams in the San Francisco River Basin in the six-basin study area, New Mexico and parts of bordering States and Mexico, water years 1985-2013.

\section{Tables}

1. Attributes of selected streamgages by river basin, listed in downstream order, in the six-basin study area, New Mexico and parts of bordering States and Mexico.

2. Summary of annual inflow, outflow, outflow minus inflow, annual mean, and total streamflow for selected streamgages on major streams in the six-basin study area, New Mexico and parts of bordering States and Mexico, water years 1985-2013.

3. Annual streamflow and annual difference in streamflow by reach for selected streamgages on the Rio Grande in the six-basin study area, New Mexico and parts of bordering States and Mexico, water years 1985-2013. 
4. Annual streamflow and annual difference in streamflow by reach for selected streamgages on Rio Grande tributaries in the six-basin study area, New Mexico and parts of bordering States and Mexico, water years 1985-2013.

5. Annual streamflow and annual difference in streamflow by reach for selected Pecos River Basin streamgages in the six-basin study area, New Mexico and parts of bordering States and Mexico, water years 1985-2013

6. Annual streamflow and annual difference in streamflow by reach for selected San Juan River Basin streamgages in the six-basin study area, New Mexico and parts of bordering States and Mexico, water years 1985-2013.

7. Annual streamflow and annual difference in streamflow by reach for selected Canadian River Basin streamgages in the six-basin study area, New Mexico and parts of bordering States and Mexico, water years 1985-2013

8. Annual streamflow and annual difference in streamflow by reach for selected Gila River Basin streamgages in the six-basin study area, New Mexico and parts of bordering States and Mexico, water years 1985-2013..........54

9. Annual streamflow and annual difference in streamflow by reach for selected San Francisco River Basin streamgages in the six-basin study area, New Mexico and parts of bordering States and Mexico, water years 1985-2013.

\section{Conversion Factors}

Inch/Pound to International System of Units

\begin{tabular}{|c|c|c|}
\hline Multiply & By & To obtain \\
\hline \multicolumn{3}{|c|}{ Length } \\
\hline foot $(\mathrm{ft})$ & 0.3048 & meter $(\mathrm{m})$ \\
\hline \multicolumn{3}{|c|}{ Area } \\
\hline square mile $\left(\mathrm{mi}^{2}\right)$ & 2.590 & square kilometer $\left(\mathrm{km}^{2}\right)$ \\
\hline \multicolumn{3}{|c|}{ Volume } \\
\hline acre-foot (acre-ft) & 1,233 & cubic meter $\left(\mathrm{m}^{3}\right)$ \\
\hline \multicolumn{3}{|c|}{ Flow rate } \\
\hline acre-foot per day (acre-ft/d) & 0.01427 & cubic meter per second $\left(\mathrm{m}^{3} / \mathrm{s}\right)$ \\
\hline acre-foot (acre-ft) & 1,233 & cubic meter $\left(\mathrm{m}^{3}\right)$ \\
\hline cubic foot per second $\left(\mathrm{ft}^{3} / \mathrm{s}\right)$ & 0.02832 & cubic meter per second $\left(\mathrm{m}^{3} / \mathrm{s}\right)$ \\
\hline
\end{tabular}

\section{Datums}

Vertical coordinate information is referenced to the National Geodetic Vertical Datum of 1929 (NGVD 29).

Horizontal coordinate information is referenced to the North American Datum of 1983 (NAD 83). 


\title{
Assessment of Statewide Annual Streamflow in New Mexico, 1985-2013
}

\author{
By Joseph A. Affinati and Nathan C. Myers
}

\section{Abstract}

In 2014, the New Mexico Water Resources Research Institute began a statewide assessment of the water resources of New Mexico. The U.S. Geological Survey, in cooperation with the New Mexico Water Resources Research Institute, addressed the streamflow component of the assessment by examining streamgage data for major river basins and streams in New Mexico for the study period over water years 19852013 (all references to years in this report are to water years).

Overall, the total annual inflow to and outflow from New Mexico generally decreased over the study period. The highest annual flows for the Rio Grande occurred in 1985-87, and except at the Rio Grande below Elephant Butte Dam, N. Mex. (08361000), and Rio Grande at El Paso, Texas (08364000), streamgages, the lowest flows occurred in 2002-03. Reaches from the Colorado-New Mexico State line southward to Los Alamos, N. Mex. (reaches RG-1 through RG-4), were all gaining reaches. Based on mean annual streamflow during the study period, reaches from Los Alamos (reach RG-5) southward to El Paso (reach RG-9) were all losing reaches except for the Socorro, N. Mex., reach (reach RG-7). From 1985 to 1995 , annual flows in the Red River generally were above the mean annual streamflow, but after 1995, annual flows were more frequently below the mean annual streamflow. The Rio Hondo, Rio Pueblo de Taos, and Jemez River followed similar annual trends as the Red River, but to a lesser extent, over the study period.

Over the study period, annual flows in the Rio Chama generally increased downstream, and after 1995, the frequency of above average annual flows decreased, and below average flows became more frequent. The Rio Chama reaches were gaining in most of the years from 1985 to 2013. The Rio Puerco annual flows, at both of the streamgages on this stream, generally decreased after 2000. Reach RP-1 was a gaining reach for 24 years of the study period.

In general, Pecos River annual flows decreased substantially from the mean annual streamflow after 2000. The greatest gain on the Pecos River was estimated for the reach below Lake Sumner (reach PEC-5), which had gains in all 29 years of the study, whereas the reach from Lake Avalon southward to Red Bluff Reservoir (reach PEC-9) had losses in all 29 years. The highest flows at all streamgages on the Rio Hondo occurred in 1987; high flows there have generally decreased since 1992. Reaches from Ruidoso to below Two Rivers Reservoir, reaches RH-1 and RH-2, were losing reaches for 16 years and 28 years, respectively, over the study period.

The San Juan River for the study period had some of the highest flows of any river in New Mexico, and flow on the river generally increased in the downstream direction. Annual flows at the Animas River streamgages were highly variable but after 1993, generally, tended to decrease. The extended periods of high flows on the Animas River seemed to end in 2000. Over the study period, the reach from the New Mexico border southward to Farmington, N. Mex. (reach ANI-1), generally was a losing reach except for 1987 and 1997. Annual flows at the La Plata River near Farmington, N. Mex. (09367500), streamgage generally were less than the annual inflow to the State at the La Plata River at Colorado-New Mexico State line (09366500) streamgage. Over the study period, the reach from the New Mexico border southward to Farmington (reach PLA-1) generally was a losing reach except for 1986,1987 , and 1993.

Prior to 1999, annual flows at Canadian River streamgages varied above and below average, but after 1999, annual flows generally were below average. The Canadian River reaches, below the confluence of the Cimarron River (reach CAN-1) and the Canadian River to Ute Reservoir (reach CAN-2), display that the upstream reach (reach CAN-1) was a gaining reach for all 29 water years but that the downstream reach (reach CAN-2) was a losing reach for all years except 2003. Annual flows for the Cimarron River varied above and below average until 1999 and then generally were below average through 2013. The Cimarron River reach, below Eagle Nest Lake to about halfway to the confluence with the Canadian River (reach CIM-1), generally was a gaining reach except for 1996, 2002, 2011, and 2013.

Gila River annual flows varied above and below average until 2005 and thereafter generally were below average. Over the study period, the reach from the Gila River near Gila, N. Mex. (09430500), streamgage to the Gila River below Blue Creek, near Virden, N. Mex. (09432000), streamgage (reach GIL-1) was a gaining reach for all years except 1990 and 2013, while the reach from the Gila River below Blue 
Creek, near Virden, N. Mex. (09432000), streamgage to the Gila River near Clifton, Ariz. (09442000), streamgage (reach GIL-2) was a losing reach for all years with data except 1999.

The San Francisco River annual flows were relatively high compared to other years in the study in 1985, 1991-93, 1995, and 2005 but were near or below average for the rest of the years of the study. Both reaches on the San Francisco River were gaining reaches for all 29 years of the study.

\section{Introduction}

In 2014, the New Mexico Water Resources Research Institute began a statewide assessment of the water resources of New Mexico (New Mexico Water Resources Research Institute, 2014). The assessment includes estimates of precipitation, groundwater recharge, evapotranspiration, changes in groundwater storage, and streamflow. The components of the statewide water resources assessment are being addressed by various groups of researchers; the U.S. Geological Survey (USGS), in cooperation with the New Mexico Water Resources Research Institute, addressed the streamflow component by examining streamgage data for major river basins and streams in New Mexico for the study period over water years 1985-2013 (all references to years in this report are to water years; a water year is the 12-month period October 1 through September 30 designated by the calendar year in which it ends).

Most of New Mexico is located within an arid to semiarid climate zone (Levick and others, 2008). Surface water currently provides about 50 percent of the annual water supply (Longworth and others, 2008). Under interstate compact regulations and international treaties, water in streams crossing New Mexico's borders must be shared with the bordering States and Mexico (New Mexico Interstate Stream Commission, 2015), but the amount of water available from year to year can vary widely. Within the State, the quantity and timing of streamflow in many river reaches are controlled by a system of dams and reservoirs (Kelly, 2011). In addition, recent studies have shown that the timing and availability of spring runoff are changing (Stewart and others, 2004; Dettinger, 2005; Hidalgo and others, 2009; Clow, 2010; Llewellyn and Vaddey, 2013). Lins (2005) has shown that trends in the departure from long-term average streamflow parameters (maximum, minimum, and median) can change abruptly and are not always predictable. Because changes in streamflow could substantially affect the way surface water must be managed in New Mexico, it is important that water managers have a readily available and up-to-date assessment of surface-water resources.

Major river basins and streams in New Mexico included in this study are the Rio Grande and the Pecos, San Juan, Canadian, Gila, and San Francisco Rivers (fig. 1). With its headwaters in Colorado, the Rio Grande is the longest river in New Mexico. The Rio Grande drains most of the central part of the State and exits the southern border of the State near El Paso, Texas. The Pecos River originates in New Mexico, drains the east-central and southeastern parts of the State, and exits the State on its southern border. The San Juan River originates in Colorado, flows southwest into New Mexico, and exits the State near the Four Corners area, the conjunction of Utah, Colorado, New Mexico, and Arizona. The Canadian River originates in New Mexico and Colorado, drains the northeastern part of New Mexico, and exits the State on its eastern border. The Gila and San Francisco Rivers originate in New Mexico and flow west into Arizona.

\section{Purpose and Scope of Report}

This report presents the results of a statewide assessment of annual streamflow for the study period from 1985 to 2013 at selected streamgages in New Mexico and bordering States and only quantifies the volume of streamflow entering and exiting New Mexico. Annual differences in streamflow along river reaches were also used to identify areas where streamflow gains and losses occur along selected streams within New Mexico; however, in this study there was no attempt to determine the causes of gains and losses.

\section{Previous Studies}

Many studies have analyzed streamflow characteristics over parts of New Mexico, but few studies have encompassed the entirety of the State. Two studies covered the geographic area of New Mexico: (1) the New Mexico Interstate Stream Commission and New Mexico Office of the State Engineer (2002) published a water resource atlas for the State, which contains graphical streamflow information for selected streamgages, and (2) Waltemeyer (1989) conducted a statewide assessment of streamflow conditions and presented statistical summaries of streamflow (mean monthly and mean annual streamflow, low- and high-flow frequencies, and flow duration) collected at 169 streamgages in the State. In two studies that extended beyond the boundaries of New Mexico, Waltemeyer $(1996,2008)$ presented analyses of the frequency and recurrence of peak streamflow at selected streamgages in New Mexico. 


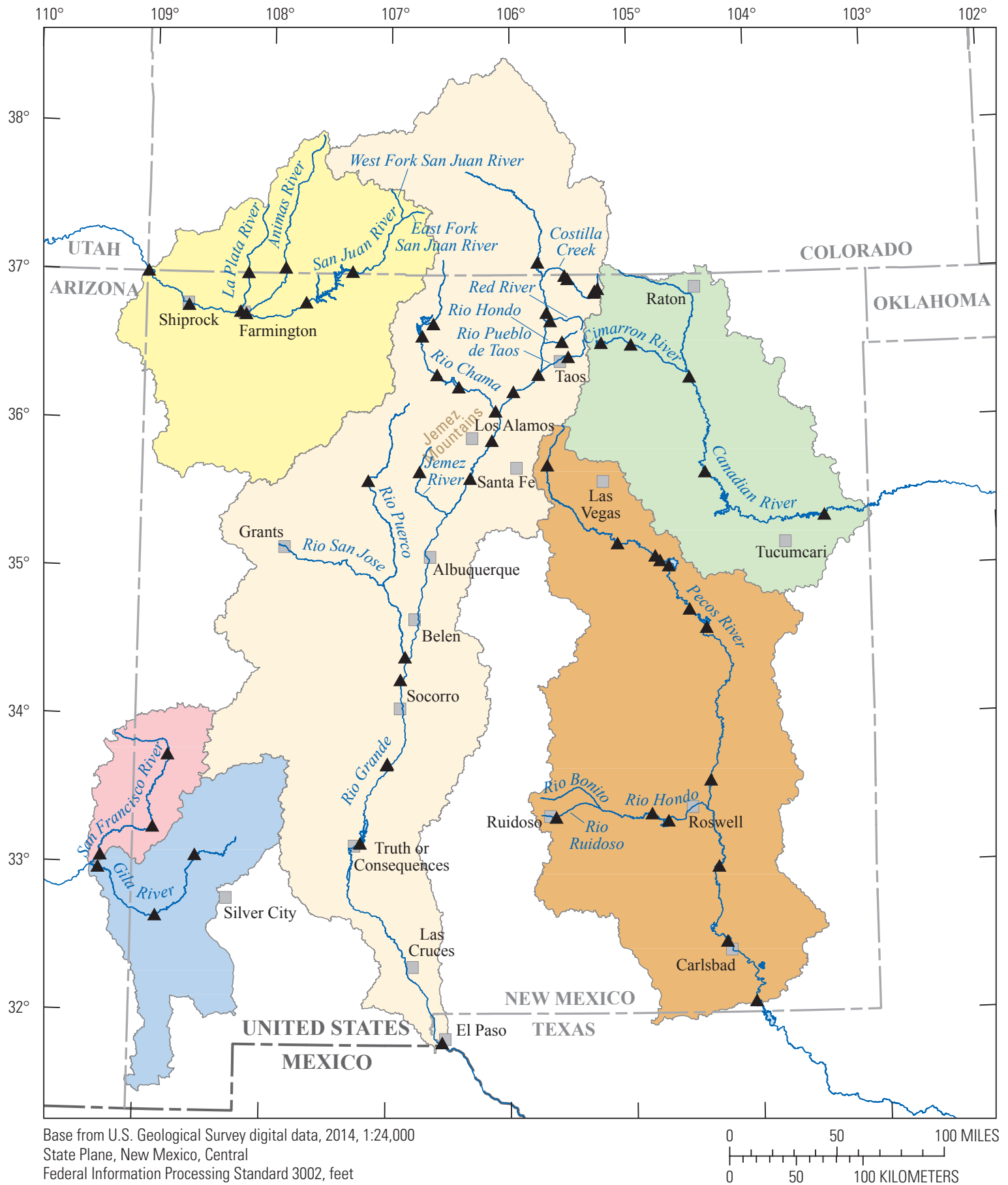
North American Datum of 1983

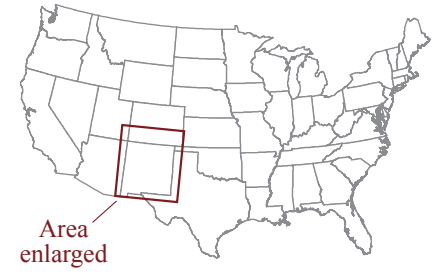

EXPLANATION

Extent of river basin in study area

Rio Grande

Pecos River

San Juan River

Canadian River

Gila River

San Francisco River

$\Delta$ Streamgage

Figure 1. River basins, rivers, and streamgages selected for study of annual streamflow in the six-basin study area, New Mexico and parts of bordering States and Mexico, water years 1985-2013. 


\section{Approach}

\section{Criteria for Selecting Streams and Streamgages}

Criteria for selecting major streams for this study included the following:

- The major stream must be perennial over most of its course in New Mexico.

- The major stream originates in New Mexico or an adjacent State and flows through New Mexico and then exits at the New Mexico border.

- Tributaries to the major streams must have one or more streamgages and must contribute a substantial amount of water to the major stream.

Criteria for selecting streamgages for this study included the following:

- The streamgage is a continuous record streamgage with streamflow data for the entire study period (1985-2013).

- The streamgage is on a major stream or a tributary to a major stream.

- The streamgage is located in New Mexico or in an adjoining State if there is no streamgage near the border in New Mexico.

- If possible, the streamgage was upstream or downstream from reservoirs.

- The streamgage accounts for all of the water in the stream (none of the water bypasses the streamgage in irrigation conveyances or is otherwise diverted immediately upstream from the streamgage).

The USGS network of streamgages was not established for the purpose of conducting a statewide water assessment; however, a sufficient number of streamgages in appropriate locations were identified for an analysis of surface-water resources. New Mexico streamgages were examined to find those closest to State borders, and preference was given to streamgages closest to the New Mexico border if located in another State. Most streamgages where the flow was not confined to one channel were eliminated, but in one case, the streamflow at two streamgages was combined (Rio Grande Conveyance Channel at San Marcial, N. Mex. [08358300], and Rio Grande Floodway at San Marcial, N. Mex.

[08358400]) (table 1).

\section{Data Sources and Uncertainty}

Annual and monthly streamflow data for the network of USGS streamgages in New Mexico and adjacent States were obtained from the USGS National Water Information System (NWIS) database and NWISWeb site (http://waterdata.usgs. gov/nwis/sw). Instrumentation at each streamgage records the height of water above a datum in the stream at 15-minute intervals. Streamflow is computed on the basis of a stagestreamflow relation that is established on the basis of manual streamflow measurements at each streamgage site. Multiple streamflow measurements are made every year at each streamgage by following standard USGS protocols (Rantz and others, 1982; Kilpatrick and Schneider, 1983; Nolan and Shields, 2000; Oberg and others, 2005; Turnipseed and Sauer, 2010). Each streamflow record is assigned a qualitative accuracy rating by the hydrographer on the basis of an assessment of many factors that affect the accuracy of the record. The qualitative accuracy ratings ("excellent," "good," "fair," and "poor") provide a measure of uncertainty for each streamflow record. "Excellent" means that about 95 percent of the daily discharges are within 5 percent of the true value, "good" within 10 percent, and "fair" within 15 percent. Records that do not meet the criteria mentioned are rated "poor" (Borland and Beal, 1988). The majority of accuracy ratings for streamflow measurements for this study ranged from "good" to "fair," with 17 percent being "poor," one rating being "excellent," and 2.3 percent having no accuracy ratings available (app. 1).

The standard value of streamflow reported by the USGS is daily mean streamflow in cubic feet per second. Values of total monthly and annual streamflow are computed by the USGS Automated Data Processing System (ADAPS) by summing the daily mean streamflow values for each month or year (Bartholoma and others, 2003). Total annual and monthly streamflow data for streamgages in New Mexico and Arizona were retrieved from ADAPS for 1985-2013. Data for Colorado streamgages for 1985-2005 were obtained from USGS annual data reports (Denis and others, 1986; Beal and Gold, 1987a; Beal and Gold, 1987b; Borland and Beal, 1988; Borland and others, 1990, 1991, 1992; Cruz and others, 1993, 1994; Borland and Ong, 1995; Ortiz and Lange, 1996, 1997; Ortiz and others, 1998, 1999, 2000, 2001; Byrd and others, 2002, 2003; Byrd and others, 2004, 2005). Data for 2006-13 for Colorado streamgages were obtained from the USGS water resources data for the United States (http://wdr.water.usgs. gov/allsearch.php). Data for the Rio Grande at El Paso, Tex. (08364000), streamgage were obtained from the United States Section of the International Boundary and Water Commission (Cliff Regensberg, written commun., 2014). 
Table 1. Attributes of selected streamgages by river basin, listed in downstream order, in the six-basin study area, New Mexico and parts of bordering States and Mexico.

[NAD 83, North American Datum of 1983; ft, feet; NGVD 29, National Geodetic Vertical Datum of 1929; mi², square miles; N. Mex., New Mexico; Colo., Colorado; *, streamgage data added together; N/A, data not available; Tex., Texas; Ariz., Arizona]

\begin{tabular}{|c|c|c|c|c|c|c|}
\hline River basin & $\begin{array}{c}\text { Station } \\
\text { identification } \\
\text { number }\end{array}$ & $\begin{array}{l}\text { Streamgage } \\
\text { name }\end{array}$ & $\begin{array}{l}\text { Latitude } \\
\text { (NAD 83) }\end{array}$ & $\begin{array}{l}\text { Longitude } \\
\text { (NAD 83) }\end{array}$ & $\begin{array}{l}\text { Elevation } \\
\text { (ft) (NGVD 29) }\end{array}$ & $\begin{array}{c}\text { Contributing } \\
\text { drainage area } \\
\left(\mathrm{mi}^{2}\right)\end{array}$ \\
\hline \multirow[t]{26}{*}{ Rio Grande Basin } & \multicolumn{6}{|c|}{ Costilla Creek } \\
\hline & 08252500 & Costilla Creek above Costilla Dam, N. Mex. & $36^{\circ} 53^{\prime} 54.1^{\prime \prime}$ & $105^{\circ} 15^{\prime} 17^{\prime \prime}$ & 9,450 & 25.1 \\
\hline & 08253500 & Santistevan Creek near Costilla, N. Mex. & $36^{\circ} 53^{\prime} 03^{\prime \prime}$ & $105^{\circ} 16^{\prime} 52^{\prime \prime}$ & 9,520 & 2.15 \\
\hline & 08254000 & Costilla Creek below Costilla Dam, N. Mex. & $36^{\circ} 52^{\prime} 22.1^{\prime \prime}$ & $105^{\circ} 17^{\prime} 01^{\prime \prime}$ & 9,300 & 54.6 \\
\hline & 08255500 & Costilla Creek near Costilla, N. Mex. & $36^{\circ} 58^{\prime} 00.7^{\prime \prime}$ & $105^{\circ} 30^{\prime} 26^{\prime \prime}$ & 7,940 & 195 \\
\hline & 08261000 & Costilla Creek near Garcia, Colo. & $36^{\circ} 59^{\prime} 20.5^{\prime \prime}$ & $105^{\circ} 31^{\prime} 57^{\prime \prime}$ & 7,820 & 200 \\
\hline & \multicolumn{6}{|c|}{ Rio Grande } \\
\hline & 08251500 & Rio Grande near Lobatos, Colo. & $37^{\circ} 04^{\prime} 42^{\prime \prime}$ & $105^{\circ} 45^{\prime} 24^{\prime \prime}$ & 7,430 & 4,760 \\
\hline & 08263500 & Rio Grande near Cerro, N. Mex. & $36^{\circ} 44^{\prime} 24.1^{\prime \prime}$ & $105^{\circ} 41^{\prime} 00^{\prime \prime}$ & 7,110 & 5,500 \\
\hline & 08276500 & $\begin{array}{l}\text { Rio Grande below Taos Junction Bridge near } \\
\text { Taos, N. Mex. }\end{array}$ & $36^{\circ} 19^{\prime} 12.1^{\prime \prime}$ & $105^{\circ} 45^{\prime} 16^{\prime \prime}$ & 6,050 & 6,790 \\
\hline & 08279500 & Rio Grande at Embudo, N. Mex. & $36^{\circ} 12^{\prime} 20^{\prime \prime}$ & $105^{\circ} 57^{\prime} 50^{\prime \prime}$ & 5,790 & 7,460 \\
\hline & 08313000 & Rio Grande at Otowi Bridge, N. Mex. & $35^{\circ} 52^{\prime} 28.2^{\prime \prime}$ & $106^{\circ} 08^{\prime} 33^{\prime \prime}$ & 5,490 & 11,360 \\
\hline & 08317400 & Rio Grande below Cochiti Dam, N. Mex. & $35^{\circ} 37^{\prime} 04.8^{\prime \prime}$ & $106^{\circ} 19^{\prime} 26^{\prime \prime}$ & 5,230 & 14,900 \\
\hline & 08354900 & Rio Grande Floodway at San Acacia, N. Mex. & $34^{\circ} 15^{\prime} 23^{\prime \prime}$ & $106^{\circ} 53^{\prime} 27^{\prime \prime}$ & 4,560 & 23,830 \\
\hline & 08358300* & $\begin{array}{l}\text { Rio Grande Conveyance Channel at San } \\
\text { Marcial, N. Mex. }\end{array}$ & $33^{\circ} 41^{\prime} 15.6^{\prime \prime}$ & $106^{\circ} 59^{\prime} 33^{\prime \prime}$ & 4,450 & N/A \\
\hline & 08358400* & $\begin{array}{l}\text { Rio Grande Floodway at San Marcial, } \\
\text { N. Mex. }\end{array}$ & $33^{\circ} 40^{\prime} 44.7^{\prime \prime}$ & $106^{\circ} 59^{\prime} 49^{\prime \prime}$ & 4,460 & 24,760 \\
\hline & 08361000 & $\begin{array}{l}\text { Rio Grande below Elephant Butte Dam, } \\
\text { N. Mex. }\end{array}$ & $33^{\circ} 08^{\prime} 54.6^{\prime \prime}$ & $107^{\circ} 12^{\prime} 24^{\prime \prime}$ & 4,240 & 26,510 \\
\hline & 08364000 & Rio Grande at El Paso, Tex. & $31^{\circ} 48^{\prime} 10^{\prime \prime}$ & $106^{\circ} 32^{\prime} 27^{\prime \prime}$ & 3,720 & 29,270 \\
\hline & \multicolumn{6}{|c|}{ Rio Grande tributaries } \\
\hline & 08266820 & $\begin{array}{l}\text { Red River below Fish Hatchery, near Questa, } \\
\text { N. Mex. }\end{array}$ & $36^{\circ} 40^{\prime} 58.2^{\prime \prime}$ & $105^{\circ} 39^{\prime} 15^{\prime \prime}$ & 7,110 & 185 \\
\hline & 08267500 & Rio Hondo near Valdez, N. Mex. & $36^{\circ} 32^{\prime} 30.5^{\prime \prime}$ & $105^{\circ} 33^{\prime} 23^{\prime \prime}$ & 7,650 & 36.2 \\
\hline & 08269000 & Rio Pueblo de Taos near Taos, N. Mex. & $36^{\circ} 26^{\prime} 22^{\prime \prime}$ & $105^{\circ} 30^{\prime} 13^{\prime \prime}$ & 7,380 & 66.6 \\
\hline & 08284100 & Rio Chama near La Puente, N. Mex. & $36^{\circ} 39^{\prime} 45.6^{\prime \prime}$ & $106^{\circ} 38^{\prime} 00^{\prime \prime}$ & 7,080 & 480 \\
\hline & 08285500 & Rio Chama below El Vado Dam, N. Mex. & $36^{\circ} 34^{\prime} 49.4^{\prime \prime}$ & $106^{\circ} 43^{\prime} 29^{\prime \prime}$ & 6,700 & 777 \\
\hline & 08286500 & Rio Chama above Abiquiu Reservoir, N. Mex. & $36^{\circ} 19^{\prime} 07.8^{\prime \prime}$ & $106^{\circ} 35^{\prime} 58^{\prime \prime}$ & 6,280 & 1,500 \\
\hline & 08287000 & Rio Chama below Abiquiu Dam, N. Mex. & $36^{\circ} 14^{\prime} 14^{\prime \prime}$ & $106^{\circ} 25^{\prime} 03^{\prime \prime}$ & 6,040 & 2,047 \\
\hline
\end{tabular}


Table 1. Attributes of selected streamgages by river basin, listed in downstream order, in the six-basin study area, New Mexico and parts of bordering States and Mexico.Continued

[NAD 83, North American Datum of 1983; ft, feet; NGVD 29, National Geodetic Vertical Datum of 1929; mi², square miles; N. Mex., New Mexico; Colo., Colorado; *, streamgage data added together; N/A, data not available; Tex., Texas; Ariz., Arizona]

\begin{tabular}{|c|c|c|c|c|c|c|}
\hline River basin & $\begin{array}{c}\text { Station } \\
\text { identification } \\
\text { number }\end{array}$ & $\begin{array}{l}\text { Streamgage } \\
\text { name }\end{array}$ & $\begin{array}{l}\text { Latitude } \\
\text { (NAD 83) }\end{array}$ & $\begin{array}{l}\text { Longitude } \\
\text { (NAD 83) }\end{array}$ & $\begin{array}{l}\text { Elevation } \\
\text { (ft) (NGVD 29) }\end{array}$ & $\begin{array}{c}\text { Contributing } \\
\text { drainage area } \\
\left(\mathrm{mi}^{2}\right)\end{array}$ \\
\hline \multirow{5}{*}{$\begin{array}{l}\text { Rio Grande Basin- } \\
\text { Continued }\end{array}$} & \multicolumn{6}{|c|}{ Rio Grande tributaries-Continued } \\
\hline & 08290000 & Rio Chama near Chamita, N. Mex. & $36^{\circ} 04^{\prime} 24.8^{\prime \prime}$ & $106^{\circ} 06^{\prime} 42^{\prime \prime}$ & 5,650 & 3,044 \\
\hline & 08324000 & Jemez River near Jemez, N. Mex. & $35^{\circ} 39^{\prime} 43.1^{\prime \prime}$ & $106^{\circ} 44^{\prime} 36^{\prime \prime}$ & 5,620 & 470 \\
\hline & 08334000 & $\begin{array}{l}\text { Rio Puerco above Arroyo Chico near } \\
\text { Guadalupe, N. Mex. }\end{array}$ & $35^{\circ} 36^{\prime} 03.2^{\prime \prime}$ & $107^{\circ} 09^{\prime} 60^{\prime \prime}$ & 5,950 & 420 \\
\hline & 08353000 & Rio Puerco near Bernardo, N. Mex. & $34^{\circ} 24^{\prime} 37^{\prime \prime}$ & $106^{\circ} 51^{\prime} 16^{\prime \prime}$ & 4,720 & 6,220 \\
\hline \multirow[t]{16}{*}{ Pecos River Basin } & \multicolumn{6}{|c|}{ Pecos River } \\
\hline & 08378500 & Pecos River near Pecos, N. Mex. & $35^{\circ} 42^{\prime} 30.1^{\prime \prime}$ & $105^{\circ} 40^{\prime} 58^{\prime \prime}$ & 7,500 & 189 \\
\hline & 08379500 & Pecos River near Anton Chico, N. Mex. & $35^{\circ} 10^{\prime} 43.2^{\prime \prime}$ & $105^{\circ} 06^{\prime} 32^{\prime \prime}$ & 5,130 & 1,050 \\
\hline & 08382600 & $\begin{array}{l}\text { Pecos River above Canon del Uta near } \\
\text { Colonias, N. Mex. }\end{array}$ & $35^{\circ} 05^{\prime} 29^{\prime \prime}$ & $104^{\circ} 48^{\prime} 02^{\prime \prime}$ & 4,800 & 2,330 \\
\hline & 08382650 & Pecos River above Santa Rosa Lake, N. Mex. & $35^{\circ} 03^{\prime} 34^{\prime \prime}$ & $104^{\circ} 45^{\prime} 40^{\prime \prime}$ & 4,760 & 2,340 \\
\hline & 08382830 & Pecos River below Santa Rosa Dam, N. Mex. & $35^{\circ} 01^{\prime} 27^{\prime \prime}$ & $104^{\circ} 41^{\prime} 20^{\prime \prime}$ & 4,640 & 2,430 \\
\hline & 08383500 & Pecos River near Puerto de Luna, N. Mex. & $34^{\circ} 43^{\prime} 48.3^{\prime \prime}$ & $104^{\circ} 31^{\prime} 20^{\prime \prime}$ & 4,310 & 3,970 \\
\hline & 08384500 & Pecos River below Sumner Dam, N. Mex. & $34^{\circ} 36^{\prime} 14.6^{\prime \prime}$ & $104^{\circ} 23^{\prime} 17^{\prime \prime}$ & 4,140 & 4,390 \\
\hline & 08386000 & Pecos River near Acme, N. Mex. & $33^{\circ} 34^{\prime} 18.68^{\prime \prime}$ & $104^{\circ} 22^{\prime} 24.97^{\prime \prime}$ & 3,510 & 11,380 \\
\hline & 08395500 & Pecos River near Lake Arthur, N. Mex. & $32^{\circ} 59^{\prime} 21.5^{\prime \prime}$ & $104^{\circ} 19^{\prime} 16^{\prime \prime}$ & 3,330 & 14,760 \\
\hline & 08404000 & Pecos River below Avalon Dam, N. Mex. & $32^{\circ} 28^{\prime} 51.08^{\prime \prime}$ & $104^{\circ} 15^{\prime} 46.73^{\prime \prime}$ & 3,130 & 18,080 \\
\hline & 08407500 & Pecos River at Red Bluff, N. Mex. & $32^{\circ} 04^{\prime} 30.7^{\prime \prime}$ & $104^{\circ} 02^{\prime} 22^{\prime \prime}$ & 2,850 & 19,540 \\
\hline & \multicolumn{6}{|c|}{ Pecos River tributaries } \\
\hline & 08387000 & Rio Ruidoso at Hollywood, N. Mex. & $33^{\circ} 19^{\prime} 36.1^{\prime \prime}$ & $105^{\circ} 37^{\prime} 31^{\prime \prime}$ & 6,420 & 120 \\
\hline & 08390500 & $\begin{array}{l}\text { Rio Hondo at Diamond A Ranch near } \\
\text { Roswell, N. Mex. }\end{array}$ & $33^{\circ} 20^{\prime} 57^{\prime \prime}$ & $104^{\circ} 51^{\prime} 06^{\prime \prime}$ & 4,190 & 947 \\
\hline & 08390800 & $\begin{array}{l}\text { Rio Hondo below Diamond A Dam near } \\
\text { Roswell, N. Mex. }\end{array}$ & $33^{\circ} 17^{\prime} 59.5^{\prime \prime}$ & $104^{\circ} 43^{\prime} 18^{\prime \prime}$ & 3,950 & 963 \\
\hline \multirow[t]{5}{*}{ San Juan River Basin } & \multicolumn{6}{|c|}{ San Juan River } \\
\hline & 09346400 & San Juan River near Carracas, Colo. & $37^{\circ} 00^{\prime} 49.02^{\prime \prime}$ & $107^{\circ} 18^{\prime} 44.16^{\prime \prime}$ & 6,090 & 1,230 \\
\hline & 09355500 & San Juan River near Archuleta, N. Mex. & $36^{\circ} 48^{\prime} 06.8^{\prime \prime}$ & $107^{\circ} 41^{\prime} 55^{\prime \prime}$ & 5,650 & 3,260 \\
\hline & 09368000 & San Juan River at Shiprock, N. Mex. & $36^{\circ} 46^{\prime} 36^{\prime \prime}$ & $108^{\circ} 40^{\prime} 59^{\prime \prime}$ & 4,890 & 12,900 \\
\hline & 09371010 & San Juan River at Four Corners, Colo. & $37^{\circ} 00^{\prime} 04.1^{\prime \prime}$ & $109^{\circ} 01^{\prime} 47^{\prime \prime}$ & 4,600 & 14,600 \\
\hline
\end{tabular}


Table 1. Attributes of selected streamgages by river basin, listed in downstream order, in the six-basin study area, New Mexico and parts of bordering States and Mexico.Continued

[NAD 83, North American Datum of 1983; ft, feet; NGVD 29, National Geodetic Vertical Datum of 1929; mi², square miles; N. Mex., New Mexico; Colo., Colorado; *, streamgage data added together; N/A, data not available; Tex., Texas; Ariz., Arizona]

\begin{tabular}{|c|c|c|c|c|c|c|}
\hline River basin & $\begin{array}{c}\text { Station } \\
\text { identification } \\
\text { number }\end{array}$ & $\begin{array}{l}\text { Streamgage } \\
\text { name }\end{array}$ & $\begin{array}{l}\text { Latitude } \\
\text { (NAD 83) }\end{array}$ & $\begin{array}{l}\text { Longitude } \\
\text { (NAD 83) }\end{array}$ & $\begin{array}{c}\text { Elevation } \\
\text { (ft) (NGVD 29) }\end{array}$ & $\begin{array}{c}\text { Contributing } \\
\text { drainage area } \\
\left(\mathrm{mi}^{2}\right)\end{array}$ \\
\hline \multirow{5}{*}{$\begin{array}{c}\text { San Juan River Basin- } \\
\text { Continued }\end{array}$} & \multicolumn{6}{|c|}{ San Juan River tributaries } \\
\hline & 09363500 & Animas River near Cedar Hill, N. Mex. & $37^{\circ} 02^{\prime} 11.7^{\prime \prime}$ & $107^{\circ} 52^{\prime} 31^{\prime \prime}$ & 5,960 & 1,090 \\
\hline & 09364500 & Animas River at Farmington, N. Mex. & $36^{\circ} 43^{\prime} 21^{\prime \prime}$ & $108^{\circ} 12^{\prime} 06^{\prime \prime}$ & 5,280 & 1,360 \\
\hline & 09366500 & $\begin{array}{l}\text { La Plata River at Colorado-New Mexico State } \\
\text { line }\end{array}$ & $36^{\circ} 59^{\prime} 59^{\prime \prime}$ & $108^{\circ} 11^{\prime} 19^{\prime \prime}$ & 5,970 & 331 \\
\hline & 09367500 & La Plata River near Farmington, N. Mex. & $36^{\circ} 44^{\prime} 15.3^{\prime \prime}$ & $108^{\circ} 15^{\prime} 01^{\prime \prime}$ & 5,220 & 583 \\
\hline \multirow[t]{7}{*}{ Canadian River Basin } & \multicolumn{6}{|c|}{ Canadian River } \\
\hline & 07211500 & Canadian River near Taylor Springs, N. Mex. & $36^{\circ} 17^{\prime} 51.3^{\prime \prime}$ & $104^{\circ} 29^{\prime} 44^{\prime \prime}$ & 5,640 & 2,850 \\
\hline & 07221500 & Canadian River near Sanchez, N. Mex. & $35^{\circ} 39^{\prime} 17.4^{\prime \prime}$ & $104^{\circ} 22^{\prime} 43^{\prime \prime}$ & 4,500 & 5,712 \\
\hline & 07227000 & Canadian River at Logan, N. Mex. & $35^{\circ} 21^{\prime} 00^{\prime \prime}$ & $103^{\circ} 23^{\prime} 59^{\prime \prime}$ & 3,670 & 10,031 \\
\hline & \multicolumn{6}{|c|}{ Canadian River tributaries } \\
\hline & 07206000 & $\begin{array}{l}\text { Cimarron River below Eagle Nest Dam, } \\
\text { N. Mex. }\end{array}$ & $36^{\circ} 31^{\prime} 55.7^{\prime \prime}$ & $105^{\circ} 13^{\prime} 41^{\prime \prime}$ & 8,080 & 167 \\
\hline & 07207000 & Cimarron River near Cimarron, N. Mex. & $36^{\circ} 31^{\prime} 11.4^{\prime \prime}$ & $104^{\circ} 58^{\prime} 43^{\prime \prime}$ & 6,600 & 294 \\
\hline \multirow[t]{4}{*}{ Gila River Basin } & \multicolumn{6}{|c|}{ Gila River } \\
\hline & 09430500 & Gila River near Gila, N. Mex. & $33^{\circ} 03^{\prime} 41.4^{\prime \prime}$ & $108^{\circ} 32^{\prime} 15^{\prime \prime}$ & 4,650 & 1,864 \\
\hline & 09432000 & $\begin{array}{l}\text { Gila River below Blue Creek, near Virden, } \\
\text { N. Mex. }\end{array}$ & $32^{\circ} 38^{\prime} 53^{\prime \prime}$ & $108^{\circ} 50^{\prime} 43^{\prime \prime}$ & 3,880 & 3,203 \\
\hline & 09442000 & Gila River near Clifton, Ariz. & $32^{\circ} 57^{\prime} 57.23^{\prime \prime}$ & $109^{\circ} 18^{\prime} 37.25^{\prime \prime}$ & 3,340 & 4,010 \\
\hline \multirow[t]{4}{*}{ San Francisco River Basin } & \multicolumn{6}{|c|}{ San Francisco River } \\
\hline & 09442680 & San Francisco River near Reserve, N. Mex. & $33^{\circ} 44^{\prime} 12.2^{\prime \prime}$ & $108^{\circ} 46^{\prime} 16^{\prime \prime}$ & 5,820 & 350 \\
\hline & 09444000 & San Francisco River near Glenwood, N. Mex. & $33^{\circ} 14^{\prime} 49.8^{\prime \prime}$ & $108^{\circ} 52^{\prime} 48^{\prime \prime}$ & 4,560 & 1,653 \\
\hline & 09444500 & San Francisco River at Clifton, Ariz. & $33^{\circ} 02^{\prime} 58^{\prime \prime}$ & $109^{\circ} 17^{\prime} 45^{\prime \prime}$ & 3,440 & 2,763 \\
\hline
\end{tabular}


For this report, total streamflow is the sum of all annual data for a streamgage over the study period, whereas mean annual streamflow is the annual average for the streamgage over the study period. Because the timing and magnitude of streamflow in New Mexico are heavily influenced by reservoir operations (Kelly, 2011), monthly streamflow values are not discussed in this report, but the monthly values used in the annual discussion are included as appendixes to this report (apps. 2-9).

\section{Statewide Inflow and Outflow and Reach- Specific Gain/Loss Computations}

In this report, the terms "gain" and "loss" refer to many collective hydrologic processes that may contribute water to or remove water from a stream. A gain in flow between two streamgages may occur because of inflow from perennial tributary streams, inflow from intermittent and ephemeral streams, seepage of groundwater into the stream, inflow from irrigation tail water conveyances, inflow from landdrainage systems, sewage-treatment-plant discharge, urban runoff, and direct precipitation. A loss in flow between two streamgages may occur because of evaporation from streams and reservoirs, diversion of water for various uses (irrigation, public supply, maintenance of wildlife habitat, and others), and seepage of surface water into the subsurface.

The statewide tabulation of inflow to and outflow from New Mexico was computed differently for through-flowing streams (streams that originate in another State and flow through New Mexico) than for streams originating within New Mexico. For through-flowing streams (Rio Grande, San Juan River, and Costilla Creek), inflows to New Mexico were tabulated for the most upstream streamgage within New Mexico or a streamgage in an adjoining State if that streamgage was closer to the State border. Outflows from New Mexico were tabulated for the most downstream streamgage within New Mexico or a streamgage in an adjoining State if that streamgage was closer to the State border. Costilla Creek has only one streamgage that is operated year round (Costilla Creek near Costilla, N. Mex. [08255500]), and that streamgage is located near the point where Costilla Creek exits New Mexico. Consequently, only outflows were tabulated for Costilla Creek. For streams originating within New Mexico (Pecos, Canadian, Gila, and San Francisco Rivers), inflows were zero, and outflows from the State were tabulated for the most downstream streamgage within New Mexico or a streamgage in an adjoining State if that streamgage was closer to the State border. Although some of the headwater reaches of the Canadian River originate in Colorado, there are no streamgages to quantify inflow from Colorado.
For all streams, the difference between the total annual streamflow at the most downstream streamgage in New Mexico and the total annual streamflow at the most upstream streamgage on the stream (zero for streams originating within New Mexico) was computed to provide a measure of the balance of water entering and exiting the State. This balance does not account for water originating and being consumed within the State. Tributary inflows to the major streams were not included in the statewide tabulation of inflow and outflow. The intent of this study was to show generalized gains or losses in streamflow down the length of major rivers and, as such, does not differentiate sources of or sinks in streamflow within a reach.

Annual streamflow data were used to determine the gains and losses for reaches of selected streams. Streamflow at the downstream streamgage was subtracted from the streamflow at the nearest upstream streamgage for each specific stream reach to obtain annual differences. This procedure was repeated for all stream reaches defined by streamgage pairs in the study area (fig. 1).

\section{Limitations and Appropriate Use of Data}

This report does not capture all of the streamflow that occurs in New Mexico. This report accounts for major inflows to the State (where rivers originate in another State) and major outflows from the State but does not account for water that originates within New Mexico that is not measured by a streamgage. This report does not account for water in ungaged streams that cross State borders, nor does it account for runoff from precipitation or snowmelt that infiltrates the subsurface before it passes a streamgage.

Estimates of gains and losses between selected streamgages give a general indication of annual streamflow conditions, but care should be exercised when assessing the causes of changes in flow at a single streamgage or gains and losses of flow between two streamgages. Many hydrologic processes can contribute to the gain or loss of flow in a stream, as enumerated in section "Statewide Inflow and Outflow and Reach-Specific Gain/Loss Computations." The purpose of this report is to identify inflow to and outflow from the State and determine net gains and losses for streams within the State, not to identify the hydrologic processes that cause a gain or loss. Each of these hydrologic processes can be more or less active over the course of a year, and some processes may be more active in certain river reaches than in others. It is likely that combinations of gaining and losing hydrologic processes will be active in any given reach at a given time. While streamgages cannot measure or quantify the effects of each of these ongoing hydrologic processes, the difference in flow between two streamgages is a measure of the net effect of the active gaining and losing hydrologic processes. 
The data in this report provide a general assessment of the flow conditions and changes in flow conditions from 1985 to 2013. Patterns of streamflow gain and loss may show river reaches where more or less attention by water managers is needed to alleviate water stresses in New Mexico.

The data in this report should not be used to supplant streamflow estimates made by interstate compact commissions. Compact commissions utilize specific streamgages and water accounting formulae to determine adherence to compact rules and regulations. Data in this report should also not be used to supplant the New Mexico Office of the State Engineer estimates of water availability. The difference between inflow to and outflow from the State along a major stream presented in this report should not be used as a measure of how much water was consumed within the State; the actual amount could be more or less than the inflow-outflow difference because of the many hydrologic processes and human uses of water that occur within the State.

A full assessment of streamflow would require a more extensive study than afforded by the tabulation of streamflow in this report. A full assessment would require the addition of streamgages to selected streams, refinement of regression equations used to estimate flow in ungaged areas of New Mexico (Waltemeyer, 1996, 2008), and the development of watershed models encompassing the entire State.

\section{Statewide Annual Streamflow, Gains, and Losses}

Annual inflow to and outflow from New Mexico generally decreased over the study period from 1985 to 2013 (table 2). More specifically, inflows to the State decreased for 1985-90, then increased for 1991-95, were variable from 1995 to 2008, and thereafter decreased. Outflows from the State decreased sharply from 1987 to 1990 but showed an increase through 1993 despite missing data for the Gila River near Clifton, Ariz. (09442000), streamgage. Outflows varied for 1993-2008 but thereafter decreased except for a slight increase in 2013. The inflows to the State ranged from a high of 1,709,300 acre-feet (acre-ft) in 1985 to a low of 165,590 acre-ft in 2002 (table 2). The mean annual inflow over the study period was 746,718 acre-ft, and the mean annual outflow was 2,179,249 acre-ft. Caution should be used when using and interpreting the inflow and outflow values presented herein because they represent hydrologic conditions only occurring at the State border. In addition, the inflow values do not include inflow for Costilla Creek, the Canadian River, and smaller streams that flow across the New Mexico border. Outflow values do not include Gila River (Gila River near Clifton, Ariz. [09442000], streamgage) outflow for 1990-95 and do not include outflow across the New Mexico border in smaller streams.

\section{Rio Grande Basin Streamflow}

\section{Costilla Creek}

Costilla Creek, located in the northern part of the Rio Grande Basin, has four streamgages and one tributary streamgage on Santistevan Creek (fig. 2). Of the five streamgages, only one (Costilla Creek near Costilla, N. Mex. [08255500]) recorded year-round data for the entire study period. The other four streamgages were operated only during summer months. Monthly data for the five streamgages are presented in appendix 2. Because of the limited data, annual data were tabulated only for the Costilla Creek near Costilla, N. Mex. (08255500), streamgage (table 2), so gains and losses were not computed for Costilla Creek. The increases in flow between the Costilla Creek below Costilla Dam, N. Mex. (08254000), streamgage and the Costilla Creek near Costilla, N. Mex. (08255500), streamgage indicated that there were substantial gains in flow between the two streamgages. Streamgages operated year round upstream and downstream from Costilla Reservoir would provide a fuller assessment of Costilla Creek streamflow.

\section{Rio Grande}

The Rio Grande originates in southern Colorado, flows through central New Mexico, exits the State near El Paso, Tex., and forms the border between Texas and Mexico (fig. 2). Tributaries to the Rio Grande included in this study are the Red River, Rio Hondo, Rio Pueblo de Taos, Rio Chama, Jemez River, and Rio Puerco. There are Cochiti Lake, Elephant Butte Reservoir, and Caballo Reservoir on the Rio Grande and three reservoirs, Abiquiu, Heron, and El Vado, on the Rio Chama (fig. 2). Reservoir operations and diversions of water for public supply and irrigation, especially in central and southern New Mexico, alter the natural flow of the river and the streamflows measured at downstream streamgages (Kelly, 2011).

For this report, data were compiled for 10 streamgages on the Rio Grande (fig. 2; table 3) and for 11 streamgages on tributaries (fig. 2; table 4). Monthly data for these streamgages on the Rio Grande and on its tributaries are presented in appendixes 3 and 4, respectively. The data indicate an overall pattern of decreasing annual streamflow since 1985 (figs. $3 \mathrm{~A}$ and $3 B$; table 3). Except at the Rio Grande below Elephant Butte Dam, N. Mex. (08361000), streamgage and the Rio Grande at El Paso, Tex. (08364000), streamgage, the lowest flows occurred in 2002-03 (fig. 3B; table 3). Data were not available for the Rio Grande near Cerro, N. Mex. (08263500), streamgage for 1995 (fig. 3A; table 3). 
Table 2. Summary of annual inflow, outflow, outflow minus inflow, annual mean, and total streamflow for selected streamgages on major streams in the six-basin study area, New Mexico and parts of bordering States and Mexico, water years 1985-2013.

[acre-ft, acre-feet; Colo., Colorado; Tex., Texas; N. Mex., New Mexico; Ariz., Arizona; --, no data]

\begin{tabular}{|c|c|c|c|c|c|c|c|c|c|c|c|c|}
\hline \multirow{4}{*}{$\begin{array}{c}\text { Water } \\
\text { year }\end{array}$} & \multicolumn{5}{|c|}{ Through-flowing stream } & \multicolumn{4}{|c|}{ Stream originating in New Mexico } & & & \\
\hline & \multicolumn{2}{|c|}{ Rio Grande } & \multicolumn{2}{|c|}{ San Juan River } & \multirow{2}{*}{$\begin{array}{c}\text { Costilla } \\
\text { Creek }\end{array}$} & \multirow{2}{*}{$\begin{array}{c}\begin{array}{c}\text { Pecos } \\
\text { River }\end{array} \\
\text { Outflow } \\
\text { (acre-ft) }\end{array}$} & \multirow{2}{*}{$\begin{array}{c}\begin{array}{c}\text { Canadian } \\
\text { River }\end{array} \\
\text { Outflow } \\
\text { (acre-ft) }\end{array}$} & \multirow{2}{*}{$\begin{array}{c}\begin{array}{c}\text { Gila } \\
\text { River }\end{array} \\
\text { Outflow } \\
\text { (acre-ft) }\end{array}$} & \multirow{2}{*}{$\begin{array}{c}\begin{array}{c}\text { San } \\
\text { Francisco } \\
\text { River }\end{array} \\
\text { Outflow } \\
\text { (acre-ft) }\end{array}$} & \multicolumn{3}{|c|}{ All streams } \\
\hline & $\begin{array}{c}\text { Inflow } \\
\text { (acre-ft) }\end{array}$ & $\begin{array}{l}\text { Outflow } \\
\text { (acre-ft) }\end{array}$ & $\begin{array}{l}\text { Inflow } \\
\text { (acre-ft) }\end{array}$ & $\begin{array}{l}\text { Outflow } \\
\text { (acre-ft) }\end{array}$ & & & & & & & & \\
\hline & $\begin{array}{c}08251500 \\
\text { Rio Grande } \\
\text { near } \\
\text { Lobatos, } \\
\text { Colo. }\end{array}$ & $\begin{array}{c}08364000 \\
\text { Rio Grande } \\
\text { at El Paso, } \\
\text { Tex. }\end{array}$ & $\begin{array}{c}09346400 \\
\text { San Juan } \\
\text { River } \\
\text { near } \\
\text { Carracas, } \\
\text { Colo. }\end{array}$ & $\begin{array}{c}09371010 \\
\text { San Juan } \\
\text { River } \\
\text { at Four } \\
\text { Corners, } \\
\text { Colo. }\end{array}$ & $\begin{array}{c}08255500 \\
\text { Costilla } \\
\text { Creek } \\
\text { near } \\
\text { Costilla, } \\
\text { N. Mex. }\end{array}$ & $\begin{array}{c}08407500 \\
\text { Pecos } \\
\text { River at } \\
\text { Red Bluff, } \\
\text { N. Mex. }\end{array}$ & $\begin{array}{c}07227000 \\
\text { Canadian } \\
\text { River } \\
\text { at Logan, } \\
\text { N. Mex. }\end{array}$ & $\begin{array}{c}09442000 \\
\text { Gila River } \\
\text { near } \\
\text { Clifton, } \\
\text { Ariz. }^{1}\end{array}$ & $\begin{array}{c}09444500 \\
\text { San } \\
\text { Francisco } \\
\text { River } \\
\text { at Clifton, } \\
\text { Ariz. }\end{array}$ & $\begin{array}{c}\text { Inflow } \\
\text { (acre-ft) }\end{array}$ & $\begin{array}{l}\text { Outflow } \\
\text { (acre-ft) }\end{array}$ & $\begin{array}{l}\text { Outflow } \\
\text { minus } \\
\text { inflow } \\
\text { (acre-ft) }\end{array}$ \\
\hline 1985 & 840,000 & 348,700 & 869,300 & $2,695,000$ & 57,070 & 50,760 & 2,090 & 374,000 & 372,600 & $1,709,300$ & $3,900,220$ & $2,190,920$ \\
\hline 1986 & 766,800 & 705,600 & 761,300 & $2,475,000$ & 39,900 & 215,300 & 1,670 & 193,800 & 139,900 & $1,528,100$ & $3,771,170$ & $2,243,070$ \\
\hline 1987 & 915,400 & $1,414,000$ & 640,200 & $3,026,000$ & 59,860 & 215,000 & 99,900 & 142,300 & 198,400 & $1,555,600$ & $5,155,460$ & $3,599,860$ \\
\hline 1988 & 191,800 & 580,700 & 318,800 & $1,044,000$ & 24,260 & 60,480 & 3,370 & 200,300 & 193,700 & 510,600 & $2,106,810$ & $1,596,210$ \\
\hline 1989 & 241,400 & 442,500 & 358,200 & 811,700 & 28,320 & 41,180 & 13,000 & 78,180 & 70,630 & 599,600 & $1,485,510$ & 885,910 \\
\hline 1990 & 144,000 & 384,100 & 282,900 & 717,500 & 27,950 & 28,970 & 14,080 & -- & 51,510 & 426,900 & $1,224,110$ & 797,210 \\
\hline 1991 & 324,500 & 370,000 & 464,100 & $1,087,000$ & 37,790 & 57,710 & 17,670 & -- & 274,400 & 788,600 & $1,844,570$ & $1,055,970$ \\
\hline 1992 & 246,200 & 456,700 & 473,100 & $1,513,000$ & 48,170 & 160,900 & 16,770 & -- & 345,900 & 719,300 & $2,541,440$ & $1,822,140$ \\
\hline 1993 & 387,300 & 516,800 & 657,900 & $2,217,000$ & 41,250 & 66,780 & 26,350 & -- & 601,400 & $1,045,200$ & $3,469,580$ & $2,424,380$ \\
\hline 1994 & 288,900 & 485,400 & 490,100 & $1,411,000$ & 59,200 & 60,480 & 93,360 & -- & 65,960 & 779,000 & $2,175,400$ & $1,396,400$ \\
\hline 1995 & 537,100 & 705,000 & 732,600 & $2,102,000$ & 57,820 & 74,640 & 72,640 & -- & 301,300 & $1,269,700$ & $3,313,400$ & $2,043,700$ \\
\hline 1996 & 143,700 & 474,860 & 205,200 & 815,800 & 25,220 & 74,610 & 31,150 & 93,800 & 65,700 & 348,900 & $1,581,140$ & $1,232,240$ \\
\hline 1997 & 433,400 & 472,400 & 495,300 & $1,884,000$ & 30,530 & 62,430 & 52,460 & 193,000 & 112,200 & 928,700 & $2,807,020$ & $1,878,320$ \\
\hline 1998 & 352,000 & 462,400 & 406,900 & $1,402,000$ & 31,220 & 96,000 & 2,210 & 201,800 & 154,200 & 758,900 & $2,349,830$ & $1,590,930$ \\
\hline 1999 & 425,700 & 459,800 & 488,100 & $1,902,000$ & 39,550 & 82,240 & 104,800 & 95,340 & 106,600 & 913,800 & $2,790,330$ & $1,876,530$ \\
\hline 2000 & 166,800 & 433,800 & 188,400 & 928,800 & 29,780 & 55,160 & 42,860 & 42,990 & 40,560 & 355,200 & $1,573,950$ & $1,218,750$ \\
\hline 2001 & 284,600 & 459,600 & 413,300 & $1,288,000$ & 29,350 & 51,630 & 3,130 & 138,200 & 237,800 & 697,900 & $2,207,710$ & $1,509,810$ \\
\hline 2002 & 84,490 & 471,900 & 81,100 & 534,700 & 11,210 & 37,720 & 2,510 & 45,210 & 52,010 & 165,590 & $1,155,260$ & 989,670 \\
\hline 2003 & 68,710 & 211,000 & 200,600 & 635,600 & 20,760 & 32,110 & 2,810 & 47,610 & 57,940 & 269,310 & $1,007,830$ & 738,520 \\
\hline
\end{tabular}


Table 2. Summary of annual inflow, outflow, outflow minus inflow, annual mean, and total streamflow for selected streamgages on major streams in the six-basin study area, New Mexico and parts of bordering States and Mexico, water years 1985-2013.-Continued

[acre-ft, acre-feet; Colo., Colorado; Tex., Texas; N. Mex., New Mexico; Ariz., Arizona; --, no data]

\begin{tabular}{|c|c|c|c|c|c|c|c|c|c|c|c|c|}
\hline \multirow{4}{*}{$\begin{array}{l}\text { Water } \\
\text { year }\end{array}$} & \multicolumn{5}{|c|}{ Through-flowing stream } & \multicolumn{4}{|c|}{ Stream originating in New Mexico } & & & \\
\hline & \multicolumn{2}{|c|}{ Rio Grande } & \multicolumn{2}{|c|}{ San Juan River } & \multirow{2}{*}{$\begin{array}{c}\text { Costilla } \\
\text { Creek }\end{array}$} & \multirow{2}{*}{$\begin{array}{c}\text { Pecos } \\
\text { River } \\
\text { Outflow } \\
\text { (acre-ft) }\end{array}$} & \multirow{2}{*}{$\begin{array}{c}\begin{array}{c}\text { Canadian } \\
\text { River }\end{array} \\
\text { Outflow } \\
\text { (acre-ft) }\end{array}$} & \multirow{2}{*}{$\begin{array}{c}\text { Gila } \\
\text { River } \\
\text { Outflow } \\
\text { (acre-ft) }\end{array}$} & \multirow{2}{*}{$\begin{array}{c}\begin{array}{c}\text { San } \\
\text { Francisco } \\
\text { River }\end{array} \\
\text { Outflow } \\
\text { (acre-ft) }\end{array}$} & \multicolumn{3}{|c|}{ All streams } \\
\hline & $\begin{array}{c}\text { Inflow } \\
\text { (acre-ft) }\end{array}$ & $\begin{array}{l}\text { Outflow } \\
\text { (acre-ft) }\end{array}$ & $\begin{array}{c}\text { Inflow } \\
\text { (acre-ft) }\end{array}$ & $\begin{array}{l}\text { Outflow } \\
\text { (acre-ft) }\end{array}$ & & & & & & & & \\
\hline & $\begin{array}{c}08251500 \\
\text { Rio Grande } \\
\text { near } \\
\text { Lobatos, } \\
\text { Colo. }\end{array}$ & $\begin{array}{c}08364000 \\
\text { Rio Grande } \\
\text { at El Paso, } \\
\text { Tex. }\end{array}$ & $\begin{array}{c}09346400 \\
\text { San Juan } \\
\text { River } \\
\text { near } \\
\text { Carracas, } \\
\text { Colo. }\end{array}$ & $\begin{array}{c}09371010 \\
\text { San Juan } \\
\text { River } \\
\text { at Four } \\
\text { Corners, } \\
\text { Colo. }\end{array}$ & $\begin{array}{c}08255500 \\
\text { Costilla } \\
\text { Creek } \\
\text { near } \\
\text { Costilla, } \\
\text { N. Mex. }\end{array}$ & $\begin{array}{c}08407500 \\
\text { Pecos } \\
\text { River at } \\
\text { Red Bluff, } \\
\text { N. Mex. }\end{array}$ & $\begin{array}{l}07227000 \\
\text { Canadian } \\
\text { River } \\
\text { at Logan, } \\
\text { N. Mex. }\end{array}$ & $\begin{array}{c}09442000 \\
\text { Gila River } \\
\text { near } \\
\text { Clifton, } \\
\text { Ariz. }^{1}\end{array}$ & $\begin{array}{c}09444500 \\
\text { San } \\
\text { Francisco } \\
\text { River } \\
\text { at Clifton, } \\
\text { Ariz. }\end{array}$ & $\begin{array}{c}\text { Inflow } \\
\text { (acre-ft) }\end{array}$ & $\begin{array}{l}\text { Outflow } \\
\text { (acre-ft) }^{1}\end{array}$ & $\begin{array}{l}\text { Outflow } \\
\text { minus } \\
\text { inflow } \\
\text { (acre-ft) }{ }^{1,2}\end{array}$ \\
\hline 2004 & 192,100 & 182,500 & 329,600 & 740,000 & 27,060 & 87,610 & 2,710 & 98,030 & 69,610 & 521,700 & $1,207,520$ & 685,820 \\
\hline 2005 & 443,900 & 307,500 & 624,800 & $1,576,000$ & 47,760 & 98,590 & 2,790 & 301,900 & 296,100 & $1,068,700$ & $2,630,640$ & $1,561,940$ \\
\hline 2006 & 178,600 & 286,500 & 277,200 & 838,100 & 23,100 & 96,430 & 21,580 & 197,100 & 120,500 & 455,800 & $1,583,310$ & $1,127,510$ \\
\hline 2007 & 325,500 & 329,400 & 454,600 & $1,329,000$ & 36,790 & 62,660 & 2,500 & 130,700 & 97,830 & 780,100 & $1,988,880$ & $1,208,780$ \\
\hline 2008 & 430,400 & 370,100 & 561,700 & $1,992,000$ & 40,560 & 58,120 & 2,540 & 152,700 & 180,800 & 992,100 & $2,796,820$ & $1,804,720$ \\
\hline 2009 & 284,200 & 399,100 & 361,000 & 950,400 & 37,080 & 62,890 & 2,600 & 60,490 & 50,200 & 645,200 & $1,562,760$ & 917,560 \\
\hline 2010 & 219,000 & 369,100 & 376,200 & 804,700 & 37,980 & 42,570 & 2,360 & 210,500 & 193,800 & 595,200 & $1,661,010$ & $1,065,810$ \\
\hline 2011 & 182,400 & 242,400 & 337,900 & 893,500 & 18,900 & 48,200 & 2,120 & 39,580 & 43,760 & 520,300 & $1,288,460$ & 768,160 \\
\hline 2012 & 160,300 & 133,500 & 230,400 & 716,800 & 15,040 & 17,240 & 2,060 & 55,320 & 49,450 & 390,700 & 989,410 & 598,710 \\
\hline 2013 & 96,210 & 56,760 & 218,600 & 618,200 & 13,610 & 42,330 & 2,070 & 134,100 & 161,600 & 314,810 & $1,028,670$ & 713,860 \\
\hline $\begin{array}{l}\text { Annual mean, } \\
\text { 1985-2013 } \\
\text { (acre-feet per } \\
\text { year) }\end{array}$ & 322,600 & 432,142 & 424,117 & $1,343,062$ & 34,382 & 73,819 & 22,281 & 140,302 & 162,288 & 746,718 & $2,179,249$ & $1,432,531$ \\
\hline $\begin{array}{l}\text { Total, 1985-2013 } \\
\text { (acre-feet per } \\
\text { year) }\end{array}$ & $9,355,410$ & $12,532,120$ & $12,299,400$ & $38,948,800$ & 997,090 & $2,140,740$ & 646,160 & $3,226,950$ & $4,706,360$ & $21,654,810$ & $63,198,220$ & $41,543,410$ \\
\hline
\end{tabular}

'Gila River near Clifton, Ariz. Outflow values missing from water years 1990 to 1995.

${ }^{2}$ Total inflow values do not include inflow from the Canadian River and Costilla Creek. 


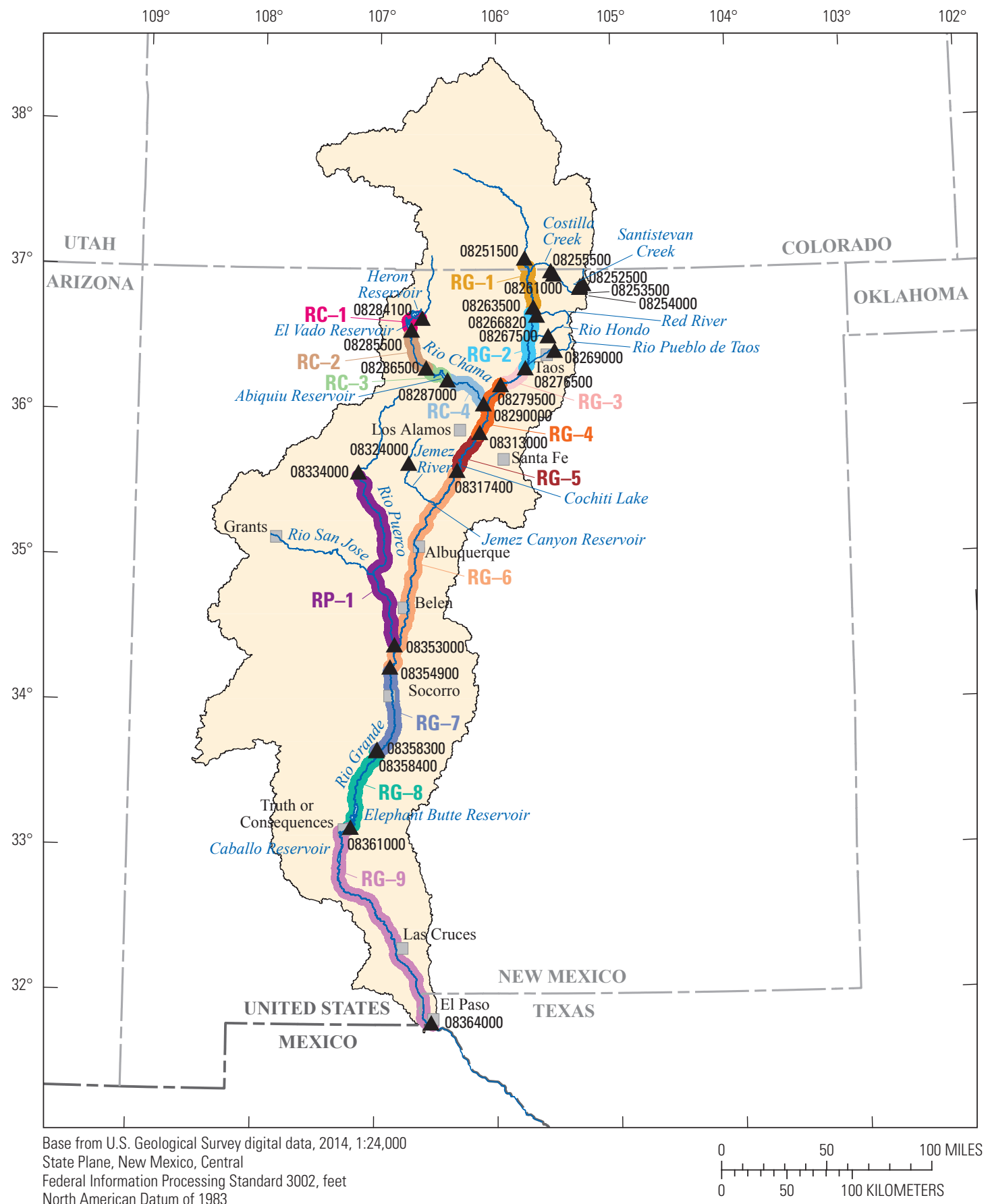

Study area

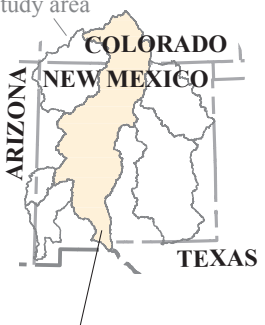

Rio Grande Basin upstream from USGS 08364000 (Rio Grande at El Paso, Tex.)

\section{EXPLANATION}

Rio Grande Basin-Upstream

from USGS 08364000 (Rio

Grande at El Paso, Tex.)

\section{RG-5}

Reach and identifier

$08255500 \begin{gathered}\text { Streamgage and station } \\ \text { identification number }\end{gathered}$

USGS, U.S. Geological Survey

Figure 2. Rio Grande Basin, streams, stream reaches, and streamgages upstream from the Rio Grande at El Paso, Texas (08364000), streamgage in the six-basin study area, New Mexico and parts of bordering States and Mexico. 
Table 3. Annual streamflow and annual difference in streamflow by reach for selected streamgages on the Rio Grande in the six-basin study area, New Mexico and parts of bordering States and Mexico, water years 1985-2013.

[Colo., Colorado; acre-ft, acre-feet; N. Mex., New Mexico; Tex., Texas; --, no data; RG, Rio Grande reach, numbered in downstream order]

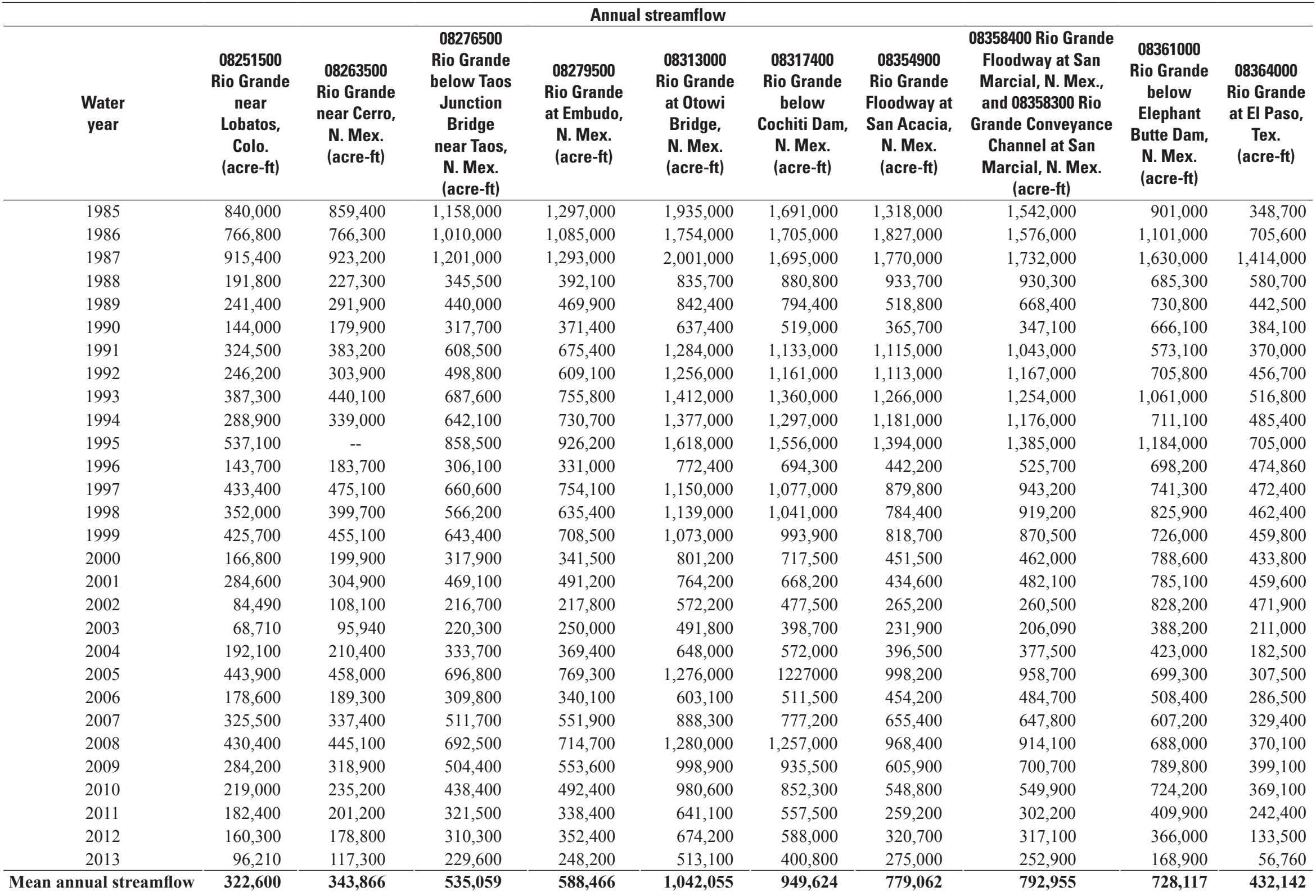


Table 3. Annual streamflow and annual difference in streamflow by reach for selected streamgages on the Rio Grande in the six-basin study area, New Mexico and parts of bordering States and Mexico, water years 1985-2013.-Continued

[Colo., Colorado; acre-ft, acre-feet; N. Mex., New Mexico; Tex., Texas; --, no data; RG, Rio Grande reach, numbered in downstream order]

\begin{tabular}{|c|c|c|c|c|c|c|c|c|c|}
\hline \multirow[b]{3}{*}{$\begin{array}{l}\text { Water } \\
\text { year }\end{array}$} & \multicolumn{8}{|c|}{ Annual difference in streamflow by reach } & \multirow[b]{2}{*}{ RG-9 } \\
\hline & RG-1 & RG-2 & RG-3 & RG-4 & RG-5 & RG-6 & RG-7 & RG-8 & \\
\hline & $\begin{array}{c}08251500 \\
\text { Rio Grande } \\
\text { near } \\
\text { Lobatos, } \\
\text { Colo., to } \\
08263500 \\
\text { Rio Grande } \\
\text { near Cerro, } \\
\text { N. Mex. } \\
\text { (acre-ft) }\end{array}$ & $\begin{array}{c}08263500 \\
\text { Rio Grande } \\
\text { near Cerro, } \\
\text { N. Mex., to } \\
08276500 \text { Rio } \\
\text { Grande below } \\
\text { Taos Junction } \\
\text { Bridge near } \\
\text { Taos, N. Mex. } \\
\text { (acre-ft) }\end{array}$ & $\begin{array}{c}08276500 \\
\text { Rio Grande } \\
\text { below Taos } \\
\text { Junction } \\
\text { Bridge near } \\
\text { Taos, N. Mex., } \\
\text { to } 08279500 \\
\text { Rio Grande at } \\
\text { Embudo, } \\
\text { N. Mex. } \\
\text { (acre-ft) }\end{array}$ & $\begin{array}{l}08279500 \\
\text { Rio Grande } \\
\text { at Embudo, } \\
\text { N. Mex., to } \\
08313000 \\
\text { Rio Grande } \\
\text { at Otowi } \\
\text { Bridge, } \\
\text { N. Mex. } \\
\text { (acre-ft) }\end{array}$ & $\begin{array}{l}08313000 \\
\text { Rio Grande } \\
\text { at Otowi } \\
\text { Bridge, N. } \\
\text { Mex., to } \\
08317400 \\
\text { Rio Grande } \\
\text { below } \\
\text { Cochiti Dam, } \\
\text { N. Mex. } \\
\text { (acre-ft) }\end{array}$ & $\begin{array}{l}08317400 \\
\text { Rio Grande } \\
\text { below } \\
\text { Cochiti Dam, } \\
\text { N. Mex., to } \\
08354900 \\
\text { Rio Grande } \\
\text { Floodway at } \\
\text { San Acacia, } \\
\text { N. Mex. } \\
\text { (acre-ft) }\end{array}$ & $\begin{array}{l}08354900 \text { Rio Grande } \\
\text { Floodway at San } \\
\text { Acacia, N. Mex., to } \\
08358400 \text { Rio Grande } \\
\text { Floodway at San } \\
\text { Marcial, N. Mex., and } \\
08358300 \text { Rio Grande } \\
\text { Conveyance Channel } \\
\text { at San Marcial, N. } \\
\text { Mex. } \\
\text { (acre-ft) }\end{array}$ & $\begin{array}{l}08358400 \text { Rio Grande } \\
\text { Floodway at San } \\
\text { Marcial, N. Mex., } \\
\text { and } 08358300 \text { Rio } \\
\text { Grande Conveyance } \\
\text { Channel at San } \\
\text { Marcial, N. Mex., to } \\
08361000 \text { Rio Grande } \\
\text { below Elephant } \\
\text { Butte Dam, N. Mex. } \\
\text { (acre-ft) }\end{array}$ & $\begin{array}{c}08361000 \\
\text { Rio Grande } \\
\text { below } \\
\text { Elephant } \\
\text { Butte Dam, } \\
\text { N. Mex., } \\
\text { to } 08364000 \\
\text { Rio Grande } \\
\text { at El Paso, } \\
\text { Tex. } \\
\text { (acre-ft) }\end{array}$ \\
\hline 1985 & 19,400 & 298,600 & 139,000 & 638,000 & $-244,000$ & $-373,000$ & 224,000 & $-641,000$ & $-552,300$ \\
\hline 1986 & -500 & 243,700 & 75,000 & 669,000 & $-49,000$ & 122,000 & $-251,000$ & $-475,000$ & $-395,400$ \\
\hline 1987 & 7,800 & 277,800 & 92,000 & 708,000 & $-306,000$ & 75,000 & $-38,000$ & $-102,000$ & $-216,000$ \\
\hline 1988 & 35,500 & 118,200 & 46,600 & 443,600 & 45,100 & 52,900 & $-3,400$ & $-245,000$ & $-104,600$ \\
\hline 1989 & 50,500 & 148,100 & 29,900 & 372,500 & $-48,000$ & $-275,600$ & 149,600 & 62,400 & $-288,300$ \\
\hline 1990 & 35,900 & 137,800 & 53,700 & 266,000 & $-118,400$ & $-153,300$ & $-18,600$ & 319,000 & $-282,000$ \\
\hline 1991 & 58,700 & 225,300 & 66,900 & 608,600 & $-151,000$ & $-18,000$ & $-72,000$ & $-469,900$ & $-203,100$ \\
\hline 1992 & 57,700 & 194,900 & 110,300 & 646,900 & $-95,000$ & $-48,000$ & 54,000 & $-461,200$ & $-249,100$ \\
\hline 1993 & 52,800 & 247,500 & 68,200 & 656,200 & $-52,000$ & $-94,000$ & $-12,000$ & $-193,000$ & $-544,200$ \\
\hline 1994 & 50,100 & 303,100 & 88,600 & 646,300 & $-80,000$ & $-116,000$ & $-5,000$ & $-464,900$ & $-225,700$ \\
\hline 1995 & -- & -- & 67,700 & 691,800 & $-62,000$ & $-162,000$ & $-9,000$ & $-201,000$ & $-479,000$ \\
\hline 1996 & 40,000 & 122,400 & 24,900 & 441,400 & $-78,100$ & $-252,100$ & 83,500 & 172,500 & $-223,340$ \\
\hline 1997 & 41,700 & 185,500 & 93,500 & 395,900 & $-73,000$ & $-197,200$ & 63,400 & $-201,900$ & $-268,900$ \\
\hline 1998 & 47,700 & 166,500 & 69,200 & 503,600 & $-98,000$ & $-256,600$ & 134,800 & $-93,300$ & $-363,500$ \\
\hline 1999 & 29,400 & 188,300 & 65,100 & 364,500 & $-79,100$ & $-175,200$ & 51,800 & $-144,500$ & $-266,200$ \\
\hline 2000 & 33,100 & 118,000 & 23,600 & 459,700 & $-83,700$ & $-266,000$ & 10,500 & 326,600 & $-354,800$ \\
\hline 2001 & 20,300 & 164,200 & 22,100 & 273,000 & $-96,000$ & $-233,600$ & 47,500 & 303,000 & $-325,500$ \\
\hline 2002 & 23,610 & 108,600 & 1,100 & 354,400 & $-94,700$ & $-212,300$ & $-4,700$ & 567,700 & $-356,300$ \\
\hline 2003 & 27,230 & 124,360 & 29,700 & 241,800 & $-93,100$ & $-166,800$ & $-25,810$ & 182,110 & $-177,200$ \\
\hline 2004 & 18,300 & 123,300 & 35,700 & 278,600 & $-76,000$ & $-175,500$ & $-19,000$ & 45,500 & $-240,500$ \\
\hline 2005 & 14,100 & 238,800 & 72,500 & 506,700 & $-49,000$ & $-228,800$ & $-39,500$ & $-259,400$ & $-391,800$ \\
\hline 2006 & 10,700 & 120,500 & 30,300 & 263,000 & $-91,600$ & $-57,300$ & 30,500 & 23,700 & $-221,900$ \\
\hline 2007 & 11,900 & 174,300 & 40,200 & 336,400 & $-111,100$ & $-121,800$ & $-7,600$ & $-40,600$ & $-277,800$ \\
\hline 2008 & 14,700 & 247,400 & 22,200 & 565,300 & $-23,000$ & $-288,600$ & $-54,300$ & $-226,100$ & $-317,900$ \\
\hline 2009 & 34,700 & 185,500 & 49,200 & 445,300 & $-63,400$ & $-329,600$ & 94,800 & 89,100 & $-390,700$ \\
\hline 2010 & 16,200 & 203,200 & 54,000 & 488,200 & $-128,300$ & $-303,500$ & 1,100 & 174,300 & $-355,100$ \\
\hline 2011 & 18,800 & 120,300 & 16,900 & 302,700 & $-83,600$ & $-298,300$ & 43,000 & 107,700 & $-167,500$ \\
\hline 2012 & 18,500 & 131,500 & 42,100 & 321,800 & $-86,200$ & $-267,300$ & $-3,600$ & 48,900 & $-232,500$ \\
\hline 2013 & 21,090 & 112,300 & 18,600 & 264,900 & $-112,300$ & $-125,800$ & $-22,100$ & $-84,000$ & $-112,140$ \\
\hline iual streamflow & 28,926 & 179,641 & 53,407 & 453,590 & $-92,431$ & $-170,562$ & 13,893 & $-64,838$ & $-295,975$ \\
\hline
\end{tabular}


Table 4. Annual streamflow and annual difference in streamflow by reach for selected streamgages on Rio Grande tributaries in the six-basin study area, New Mexico and parts of bordering States and Mexico, water years 1985-2013.

[N. Mex., New Mexico; acre-ft, acre-feet; N. Mex., New Mexico; RC, Rio Chama reach, numbered in downstream order; RP, Rio Puerco reach, numbered in downstream order]

\begin{tabular}{|c|c|c|c|c|c|c|c|c|c|c|c|}
\hline \multirow[b]{2}{*}{$\begin{array}{c}\text { Water } \\
\text { year }\end{array}$} & \multicolumn{11}{|c|}{ Annual streamflow } \\
\hline & $\begin{array}{c}08266820 \\
\text { Red River } \\
\text { below Fish } \\
\text { Hatchery, } \\
\text { near Questa, } \\
\text { N. Mex. } \\
\text { (acre-ft) }\end{array}$ & $\begin{array}{c}08267500 \\
\text { Rio Hondo } \\
\text { near Valdez, } \\
\text { N. Mex. } \\
\text { (acre-ft) }\end{array}$ & $\begin{array}{c}08269000 \\
\text { Rio Pueblo } \\
\text { de Taos } \\
\text { near Taos, } \\
\text { N. Mex. } \\
\text { (acre-ft) }\end{array}$ & $\begin{array}{c}08284100 \\
\text { Rio Chama } \\
\text { near La } \\
\text { Puente, N. } \\
\text { Mex. } \\
\text { (acre-ft) }\end{array}$ & $\begin{array}{c}08285500 \\
\text { Rio Chama } \\
\text { below } \\
\text { El Vado Dam, } \\
\text { N. Mex. } \\
\text { (acre-ft) }\end{array}$ & $\begin{array}{c}08286500 \text { Rio } \\
\text { Chama above } \\
\text { Abiquiu } \\
\text { Reservoir, } \\
\text { N. Mex. } \\
\text { (acre-ft) }\end{array}$ & $\begin{array}{c}08287000 \\
\text { Rio Chama } \\
\text { below } \\
\text { Abiquiu Dam, } \\
\text { N. Mex. } \\
\text { (acre-ft) }\end{array}$ & $\begin{array}{c}08290000 \\
\text { Rio Chama } \\
\text { near } \\
\text { Chamita, } \\
\text { N. Mex. } \\
\text { (acre-ft) }\end{array}$ & $\begin{array}{c}08324000 \\
\text { Jemez River } \\
\text { near Jemez, } \\
\text { N. Mex. } \\
\text { (acre-ft) }\end{array}$ & $\begin{array}{c}08334000 \\
\text { Rio Puerco } \\
\text { above Arroyo } \\
\text { Chico near } \\
\text { Guadalupe, } \\
\text { N. Mex. } \\
\text { (acre-ft) }\end{array}$ & $\begin{array}{c}08353000 \\
\text { Rio Puerco } \\
\text { near } \\
\text { Bernardo, } \\
\text { N. Mex. } \\
\text { (acre-ft) }\end{array}$ \\
\hline 1985 & 84,420 & 38,730 & 38,440 & 523,600 & 546,200 & 561,900 & 443,500 & 536,200 & 126,700 & 20,110 & 34,990 \\
\hline 1986 & 67,740 & 29,890 & 26,060 & 393,400 & 482,300 & 480,700 & 533,700 & 573,200 & 64,510 & 9,860 & 16,880 \\
\hline 1987 & 69,840 & 29,050 & 26,010 & 350,200 & 507,500 & 528,400 & 631,700 & 668,000 & 106,400 & 14,240 & 33,820 \\
\hline 1988 & 42,990 & 18,520 & 11,520 & 205,100 & 238,200 & 254,300 & 351,700 & 383,600 & 57,180 & 9,500 & 45,770 \\
\hline 1989 & 51,170 & 22,860 & 17,000 & 183,100 & 275,300 & 282,900 & 313,600 & 353,700 & 42,750 & 3,580 & 8,640 \\
\hline 1990 & 44,390 & 22,830 & 15,030 & 133,900 & 178,000 & 176,200 & 191,800 & 195,500 & 38,960 & 3,460 & 20,160 \\
\hline 1991 & 59,770 & 30,620 & 24,920 & 326,200 & 382,000 & 395,200 & 401,700 & 457,400 & 67,740 & 16,980 & 44,870 \\
\hline 1992 & 61,010 & 30,020 & 26,260 & 301,000 & 407,400 & 423,800 & 537,100 & 558,700 & 96,810 & 22,550 & 23,820 \\
\hline 1993 & 72,830 & 40,000 & 29,020 & 414,200 & 507,300 & 542,800 & 482,200 & 592,900 & 86,690 & 22,130 & 25,880 \\
\hline 1994 & 81,970 & 39,060 & 38,420 & 334,400 & 438,300 & 481,400 & 547,800 & 624,100 & 37,650 & 6,870 & 17,090 \\
\hline 1995 & 85,850 & 45,880 & 41,340 & 495,000 & 523,500 & 591,500 & 505,200 & 637,600 & 95,700 & 19,840 & 14,990 \\
\hline 1996 & 37,600 & 13,180 & 8,970 & 115,800 & 306,800 & 309,000 & 443,100 & 461,100 & 16,650 & 9,370 & 26,780 \\
\hline 1997 & 54,540 & 28,030 & 23,220 & 318,000 & 320,200 & 349,200 & 345,500 & 416,900 & 70,440 & 8,030 & 19,850 \\
\hline 1998 & 47,510 & 21,530 & 15,580 & 259,500 & 401,400 & 421,800 & 437,500 & 478,100 & 58,020 & 12,080 & 10,360 \\
\hline 1999 & 58,110 & 22,280 & 17,740 & 252,600 & 240,300 & 257,400 & 251,900 & 316,400 & 48,510 & 16,040 & 35,890 \\
\hline 2000 & 31,720 & 10,050 & 6,320 & 88,840 & 332,300 & 331,300 & 448,900 & 455,100 & 27,130 & 2,890 & 3,490 \\
\hline 2001 & 45,470 & 25,610 & 16,720 & 225,200 & 205,800 & 211,500 & 184,500 & 214,000 & 54,850 & 6,230 & 4,300 \\
\hline 2002 & 24,530 & 7,240 & 3,850 & 33,440 & 285,700 & 281,800 & 346,700 & 350,800 & 16,010 & 2,810 & 5,610 \\
\hline 2003 & 34,810 & 16,100 & 11,500 & 166,200 & 211,500 & 213,600 & 216,400 & 219,600 & 31,050 & 8,080 & 14,030 \\
\hline 2004 & 35,040 & 14,370 & 9,670 & 170,200 & 260,300 & 261,200 & 216,600 & 251,200 & 42,600 & 8,570 & 18,430 \\
\hline 2005 & 65,200 & 35,030 & 29,520 & 367,500 & 335,300 & 340,300 & 370,800 & 442,800 & 69,780 & 5,180 & 8,450 \\
\hline 2006 & 33,660 & 12,890 & 6,810 & 114,700 & 256,900 & 259,500 & 213,400 & 228,200 & 18,740 & 4,620 & 77,300 \\
\hline 2007 & 51,570 & 21,190 & 15,920 & 242,800 & 242,600 & 261,800 & 263,300 & 271,500 & 53,100 & 34,000 & 10,910 \\
\hline 2008 & 76,340 & 37,770 & 29,070 & 347,700 & 394,900 & 433,000 & 461,000 & 524,000 & 48,350 & 14,120 & 9,470 \\
\hline 2009 & 65,980 & 27,830 & 20,420 & 265,100 & 399,500 & 415,000 & 418,700 & 439,500 & 31,810 & 1,880 & 5,280 \\
\hline 2010 & 57,500 & 25,920 & 25,720 & 231,100 & 335,800 & 351,400 & 370,100 & 383,000 & 41,660 & 6,760 & 12,070 \\
\hline 2011 & 33,190 & 13,430 & 9,770 & 190,900 & 295,300 & 291,300 & 299,800 & 295,200 & 19,330 & 300 & 6,410 \\
\hline 2012 & 39,220 & 17,730 & 11,250 & 145,400 & 303,800 & 304,900 & 326,700 & 337,400 & 28,080 & 5,260 & 5,800 \\
\hline 2013 & 30,740 & 12,540 & 7,180 & 90,540 & 239,800 & 249,400 & 258,800 & 260,600 & 19,800 & 9,240 & 48,810 \\
\hline $\begin{array}{l}\text { an annual } \\
\text { treamflow }\end{array}$ & 53,266 & 24,489 & 19,422 & 251,228 & 339,800 & 353,879 & 372,886 & 411,252 & 52,310 & 10,503 & 21,040 \\
\hline
\end{tabular}


Table 4. Annual streamflow and annual difference in streamflow by reach for selected streamgages on Rio Grande tributaries in the six-basin study area, New Mexico and parts of bordering States and Mexico, water years 1985-2013.-Continued

[N. Mex., New Mexico; acre-ft, acre-feet; N. Mex., New Mexico; RC, Rio Chama reach, numbered in downstream order; RP, Rio Puerco reach, numbered in downstream order]

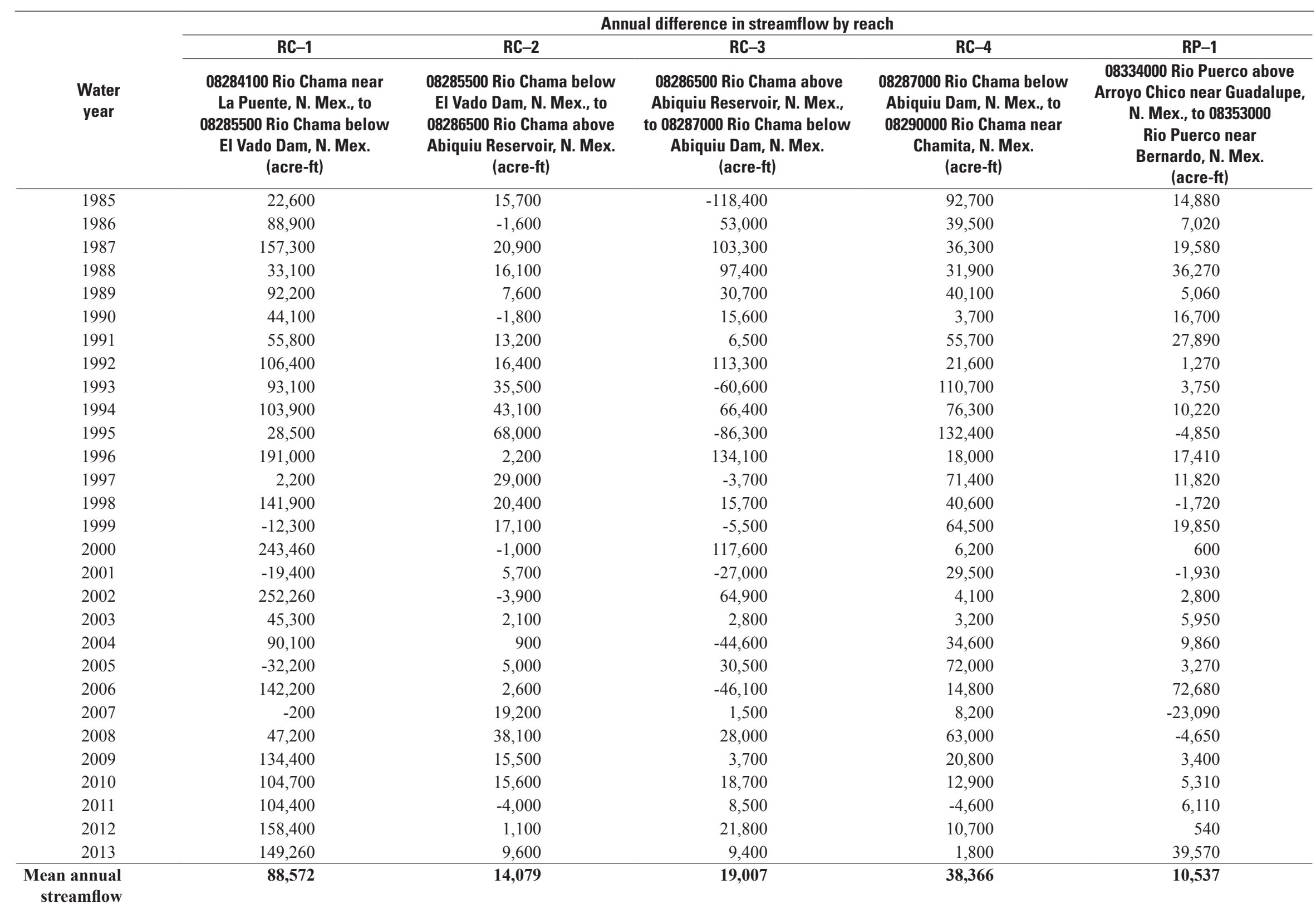




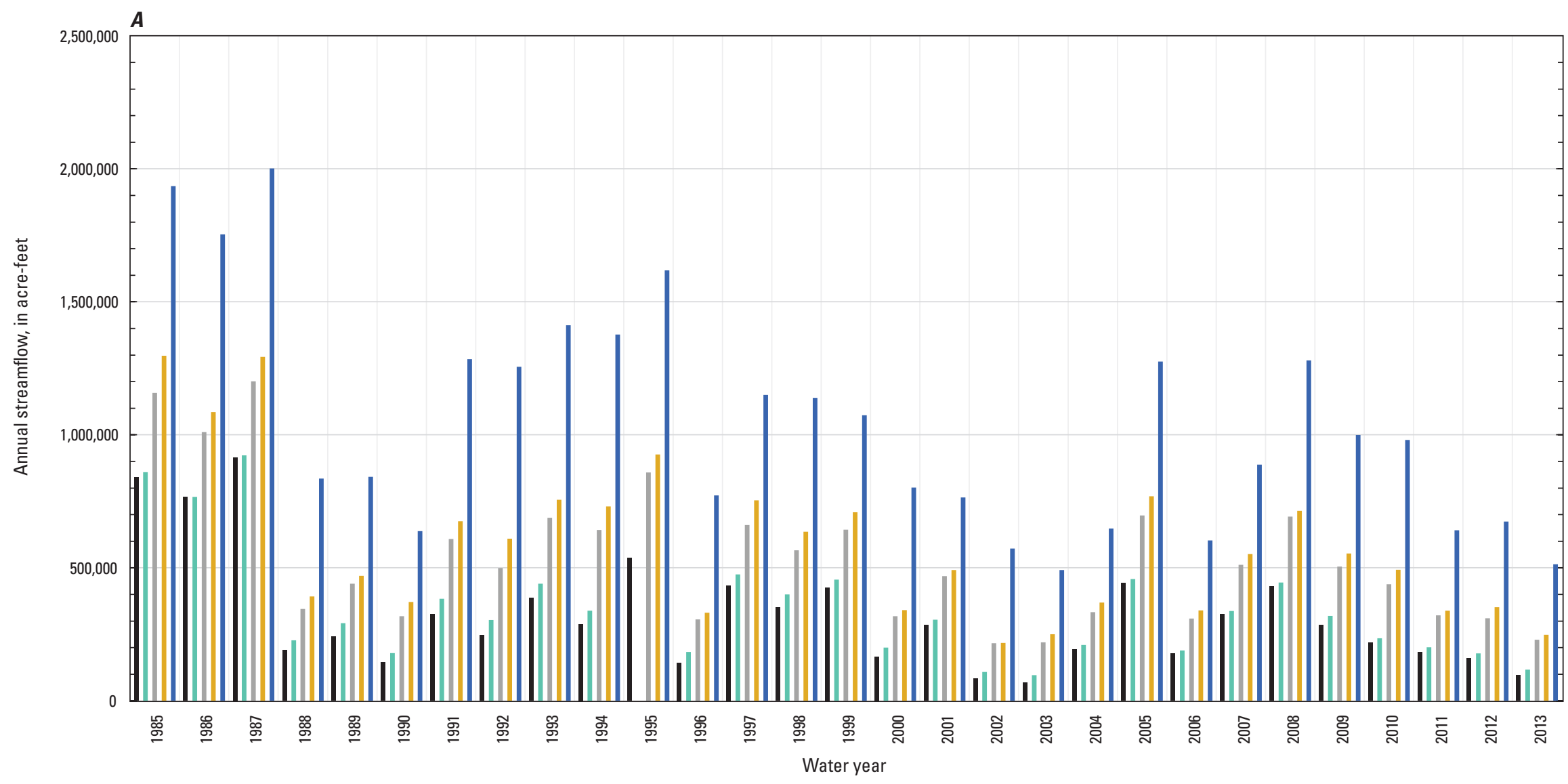

EXPLANATION

Streamgage (station identification number)

- Rio Grande near Lobatos, Colo. (08251500)

- Rio Grande near Cerro, N. Mex. (08263500)—No data for 1995

- Rio Grande below Taos Junction Bridge near Taos, N. Mex (08276500)

- Rio Grande at Embudo, N. Mex. (08279500)

- Rio Grande at Otowi Bridge, N. Mex. (08313000)

Figure 3. Annual streamflow, departure of annual streamflow from mean annual streamflow, and annual difference in streamflow for streams in the Rio Grande Basin in the sixbasin study area, New Mexico and parts of bordering States and Mexico, water years 1985-2013.

$A$, Rio Grande annual streamflow by streamgage, in downstream order, upstream from the Rio Grande at Otowi Bridge, N. Mex. (08313000), streamgage. 


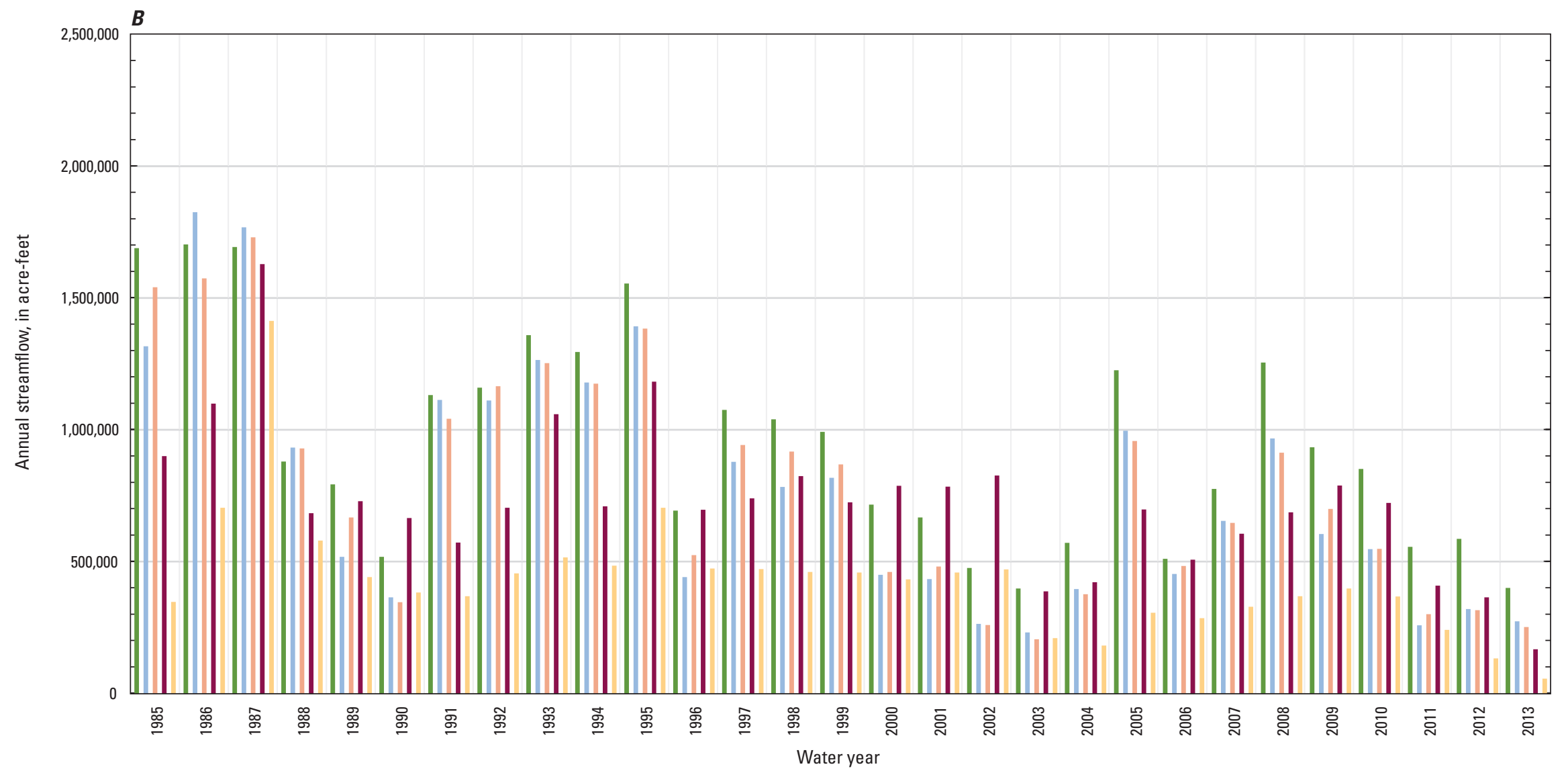

\section{EXPLANATION}

Streamgage (station identification number)

- Rio Grande below Cochiti Dam, N. Mex. (08317400)

- Rio Grande Floodway at San Acacia, N. Mex. (08354900)

- Rio Grande Floodway at San Marcial, N. Mex. (08358400*) and Rio Grande Conveyance Channel at San Marcial, N. Mex. (08358300*)

- Rio Grande below Elephant Butte Dam, N. Mex. (08361000)

Rio Grande at El Paso, Tex. (08364000)

Figure 3. Annual streamflow, departure of annual streamflow from mean annual streamflow, and annual difference in streamflow for streams in the Rio Grande Basin in the sixbasin study area, New Mexico and parts of bordering States and Mexico, water years 1985-2013.-Continued

$B$, Rio Grande annual streamflow by streamgage, in downstream order, from the Rio Grande below Cochiti Dam, N. Mex. (08317400), streamgage to the Rio Grande at El Paso, Tex. (08364000), streamgage. 


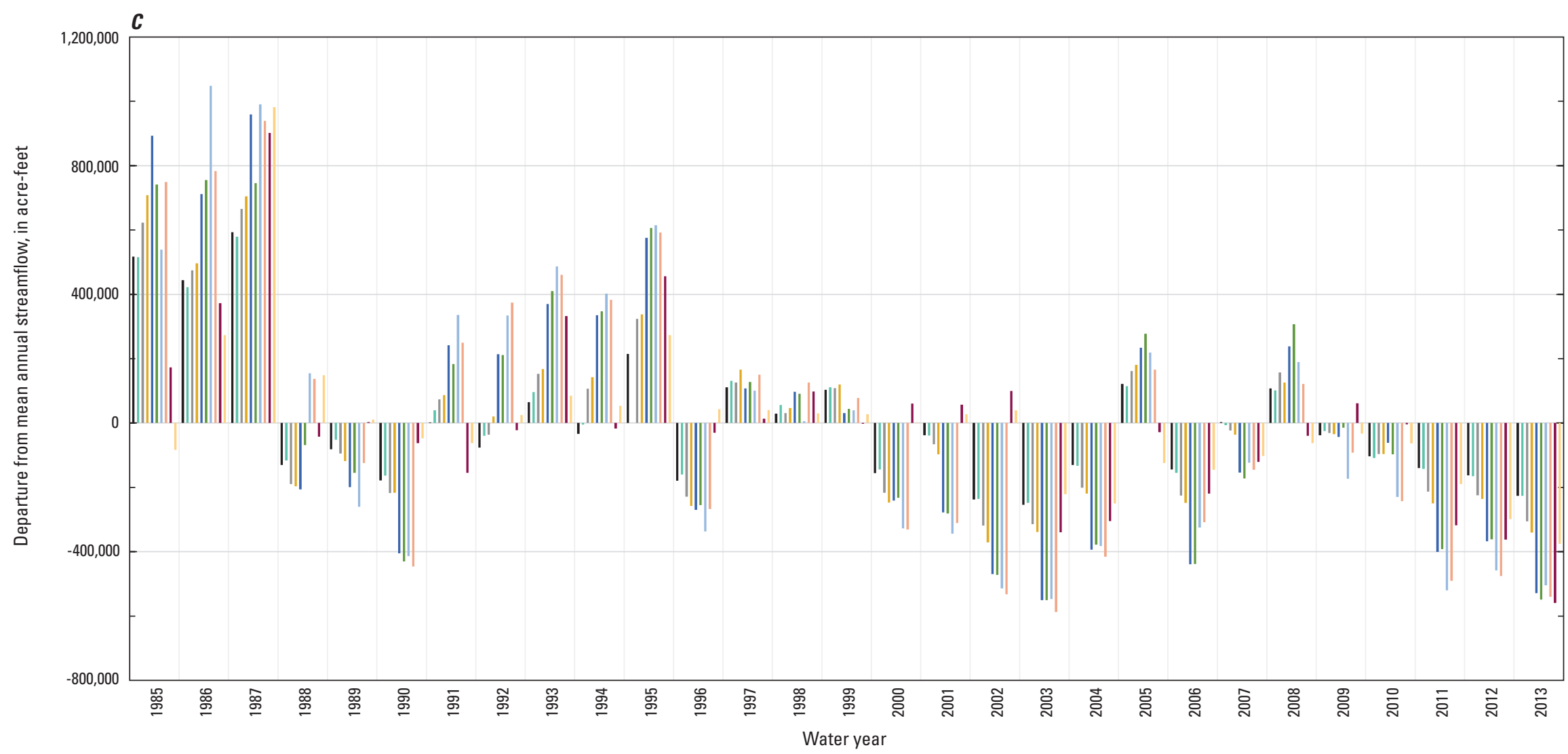

\section{EXPLANATION}

Streamgage (station identification number)

- Rio Grande near Lobatos, Colo. (08251500)

- Rio Grande below Cochiti Dam, N. Mex. (08317400)

- Rio Grande near Cerro, N. Mex. (08263500)—No data for 1995

- Rio Grande below Taos Junction Bridge near Taos, N. Mex.

- Rio Grande Floodway at San Acacia, N. Mex. (08354900)

- Rio Grande Floodway at San Marcial, N. Mex (08358400*) and Rio Grande Conveyance Channel at San Marcial, N. Mex. (08358300* (08276500)

- Rio Grande at Embudo, N. Mex. (08279500)

- Rio Grande below Elephant Butte Dam, N. Mex. (08361000)

- Rio Grande at Otowi Bridge, N. Mex. (08313000)

- Rio Grande at El Paso, Tex. (08364000)

Figure 3. Annual streamflow, departure of annual streamflow from mean annual streamflow, and annual difference in streamflow for streams in the Rio Grande Basin in the sixbasin study area, New Mexico and parts of bordering States and Mexico, water years 1985-2013.-Continued

C, Departure of annual streamflow from mean annual streamflow at Rio Grande streamgages. 


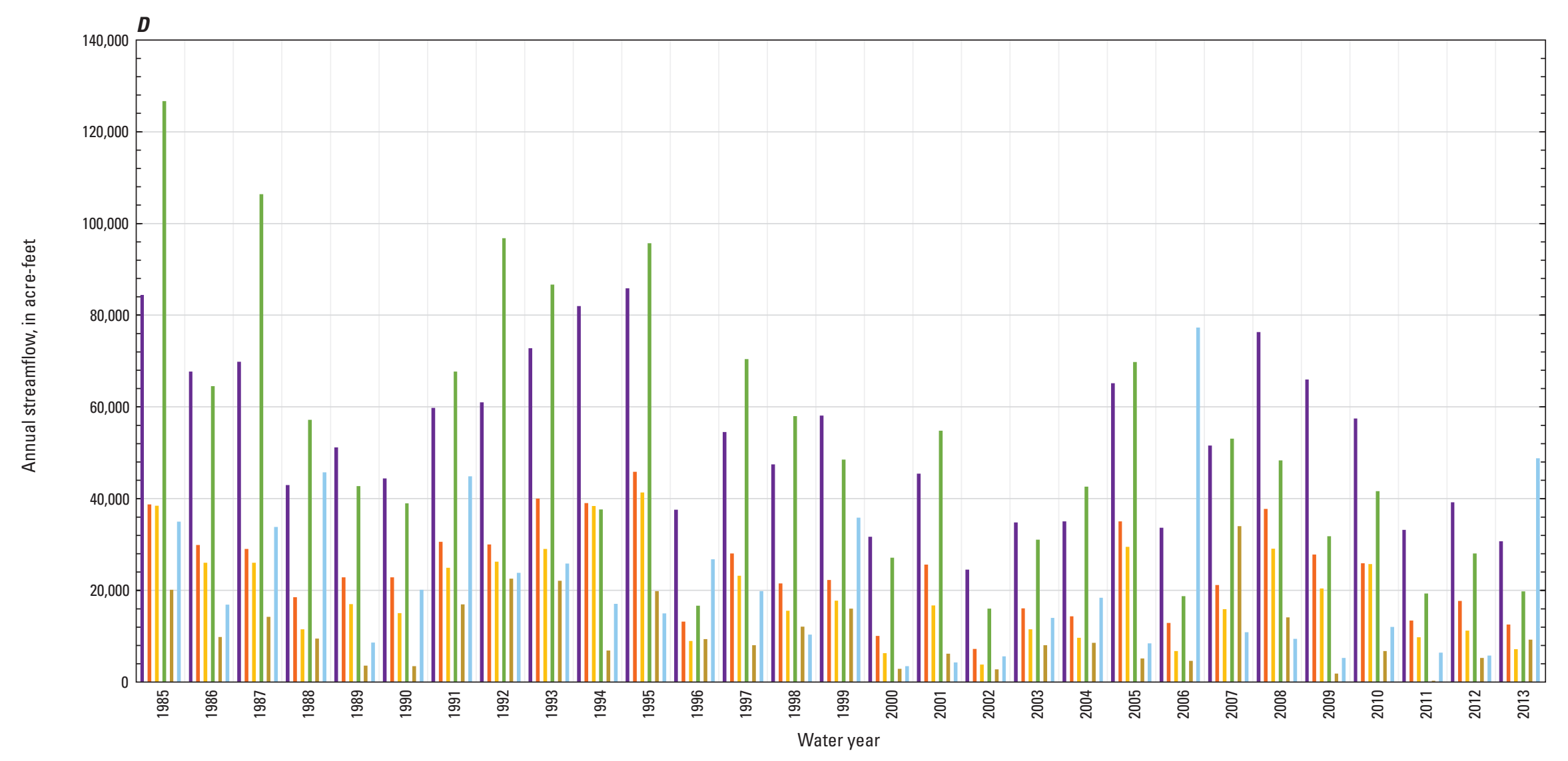

\section{EXPLANATION}

- Red River below Fish Hatchery, near Questa, N. Mex. (08266820)

- Rio Hondo near Valdez, N. Mex. (08267500)

- Rio Pueblo de Taos near Taos, N. Mex. (08269000)

- Jemez River near Jemez, N. Mex. (08324000)

- Rio Puerco above Arroyo Chico near Guadalupe, N. Mex. (08334000)

= Rio Puerco near Bernardo, N. Mex. (08353000)

Figure 3. Annual streamflow, departure of annual streamflow from mean annual streamflow, and annual difference in streamflow for streams in the Rio Grande Basin in the sixbasin study area, New Mexico and parts of bordering States and Mexico, water years 1985-2013._Continued

$D$, Rio Grande Basin tributary annual streamflow by streamgage, in downstream order. Rio Chama streamgages are omitted. 


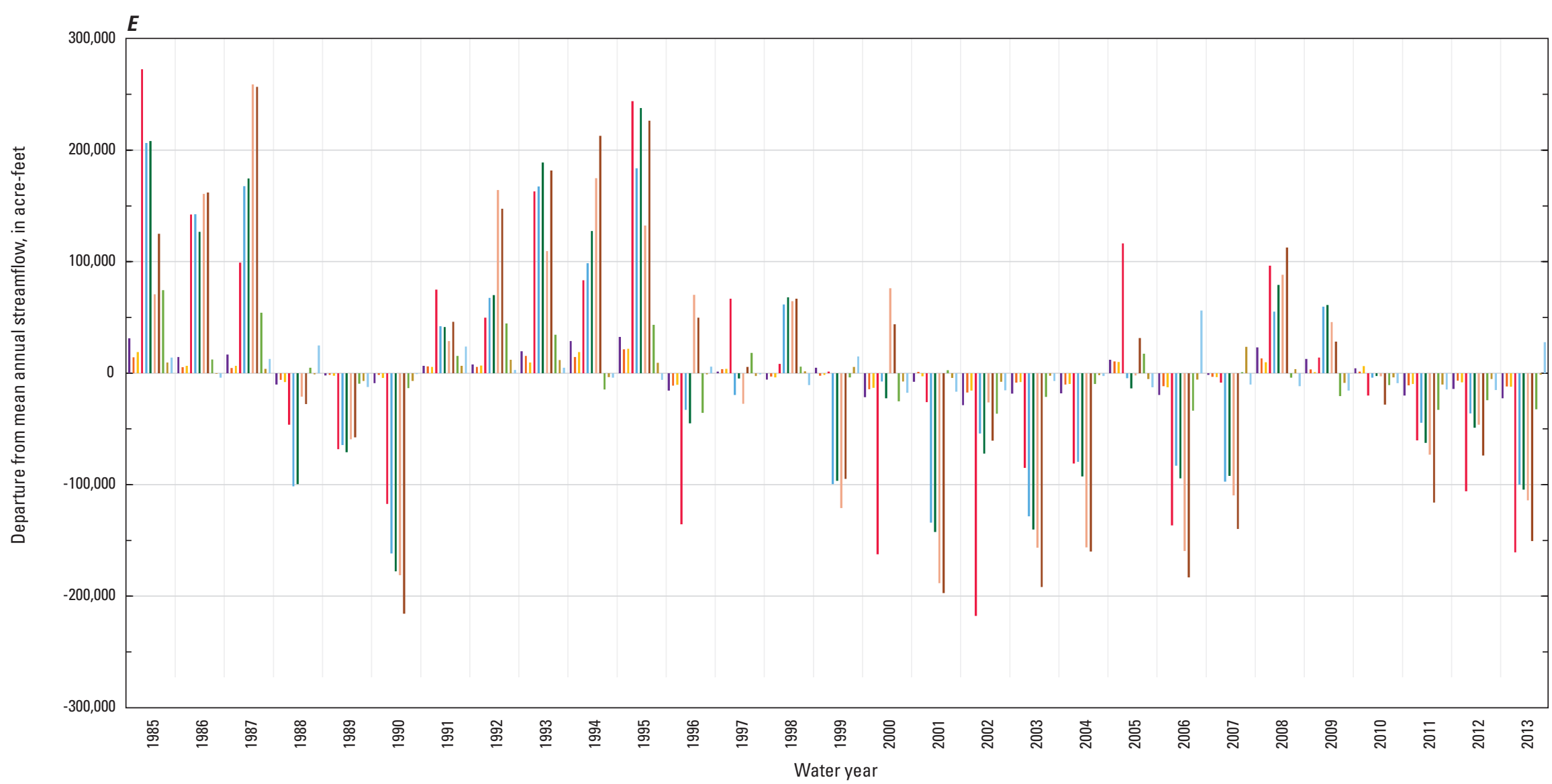

EXPLANATION

Streamgage (station identification number)

- Red River below Fish Hatchery, near Questa, N. Mex. (08266820)

- Rio Chama below Abiquiu Dam, N. Mex. (08287000)

- Rio Hondo near Valdez, N. Mex. (08267500)

- Rio Chama near Chamita, N. Mex. (08290000)

- Rio Pueblo de Taos near Taos, N. Mex. $(08269000)$

- Jemez River near Jemez, N. Mex. (08324000)

- Rio Chama near La Puente, N. Mex. (08284100)

- Rio Puerco above Arroyo Chico near Guadalupe, N. Mex. (08334000)

- Rio Chama below El Vado Dam, N. Mex. (08285500)

- Rio Puerco near Bernardo, N. Mex. (08353000)

- Rio Chama above Abiquiu Reservoir, N. Mex. (08286500)

Figure 3. Annual streamflow, departure of annual streamflow from mean annual streamflow, and annual difference in streamflow for streams in the Rio Grande Basin in the sixbasin study area, New Mexico and parts of bordering States and Mexico, water years 1985-2013.-Continued

E, Departure of annual streamflow from mean annual streamflow at Rio Grande Basin tributary streamgages. 


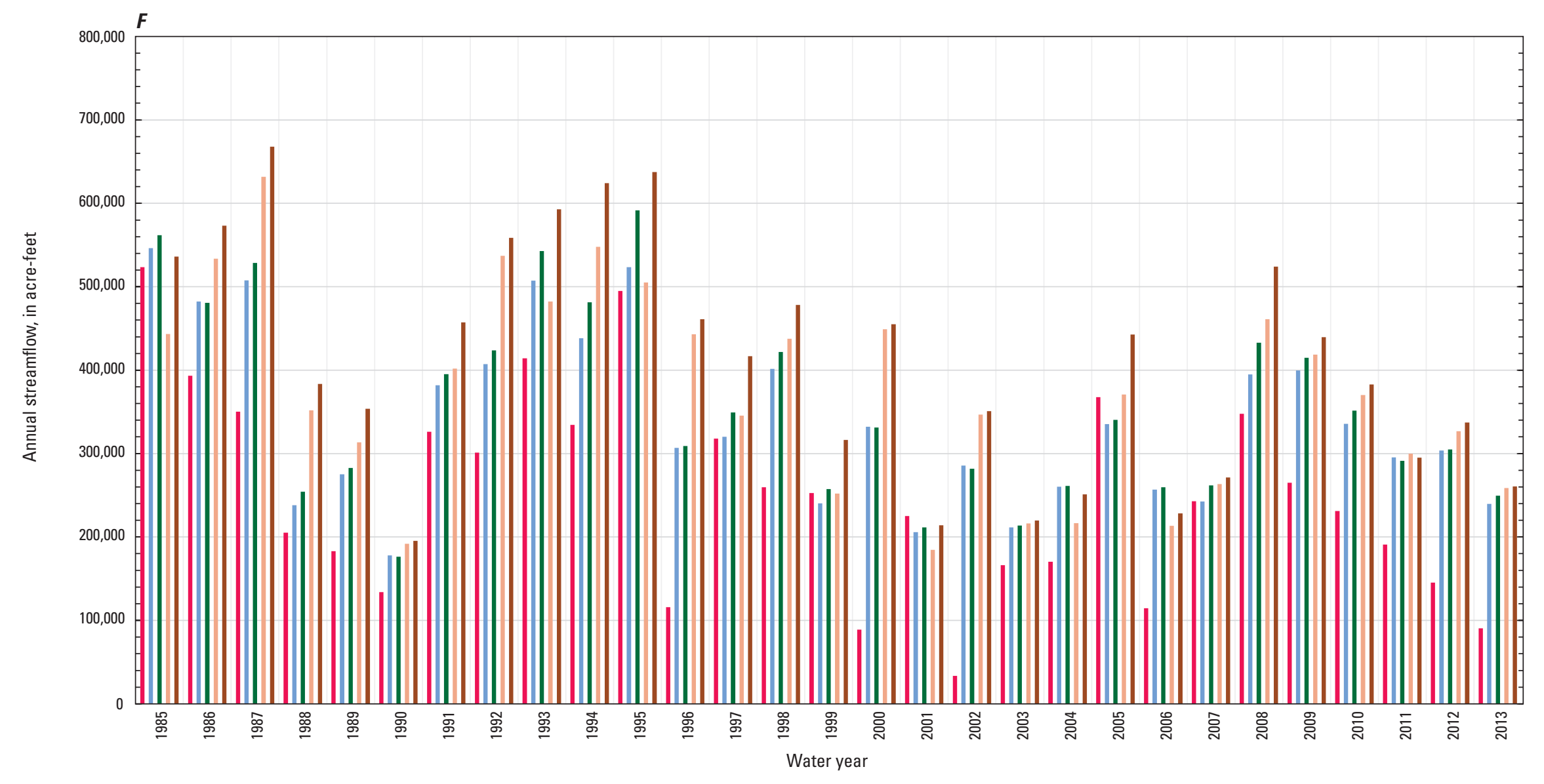

- Rio Chama near La Puente, N. Mex. (08284100)

- Rio Chama below El Vado Dam, N. Mex. (08285500)

- Rio Chama above Abiquiu Reservoir, N. Mex. (08286500)

- Rio Chama below Abiquiu Dam, N. Mex. (08287000)

- Rio Chama near Chamita, N. Mex. (08290000)

Figure 3. Annual streamflow, departure of annual streamflow from mean annual streamflow, and annual difference in streamflow for streams in the Rio Grande Basin in the sixbasin study area, New Mexico and parts of bordering States and Mexico, water years 1985-2013.-Continued

F, Rio Chama annual streamflow by streamgage, in downstream order. 


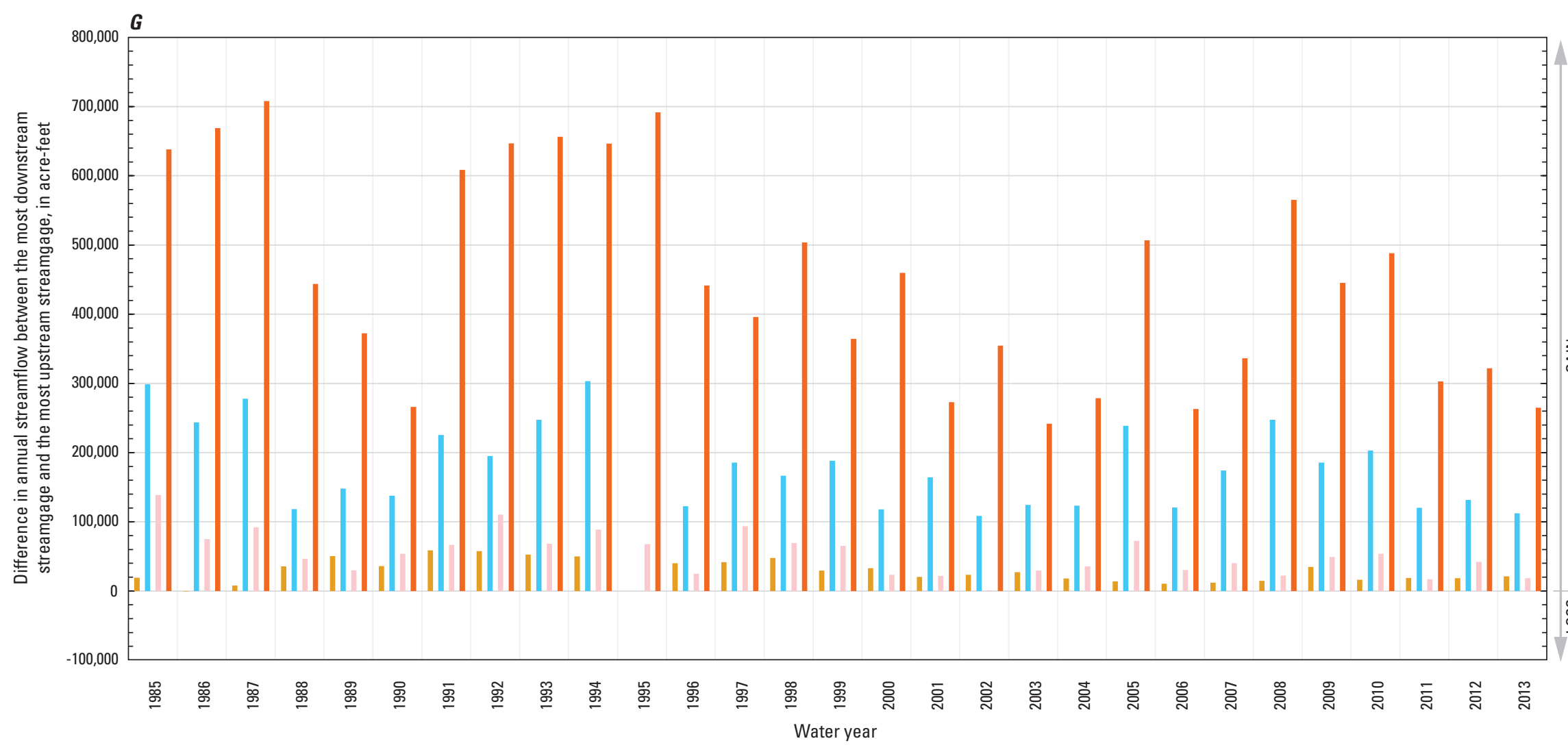

EXPLANATION

Rio Grande (RG) reach number (annual difference in streamflow)Positive average values indicate a gain over that reach

- $\mathrm{RG}-1$ (average $+28,926$ acre-feet)—No data for 1995

RG-2 (average $+179,641$ acre-feet)—No data for 1995

RG-3 (average $+53,407$ acre-feet)

- RG-4 (average $+453,590$ acre-feet)

Figure 3. Annual streamflow, departure of annual streamflow from mean annual streamflow, and annual difference in streamflow for streams in the Rio Grande Basin in the sixbasin study area, New Mexico and parts of bordering States and Mexico, water years 1985-2013.-Continued

G, Rio Grande annual difference in streamflow by reach, RG-1 to RG-4. 


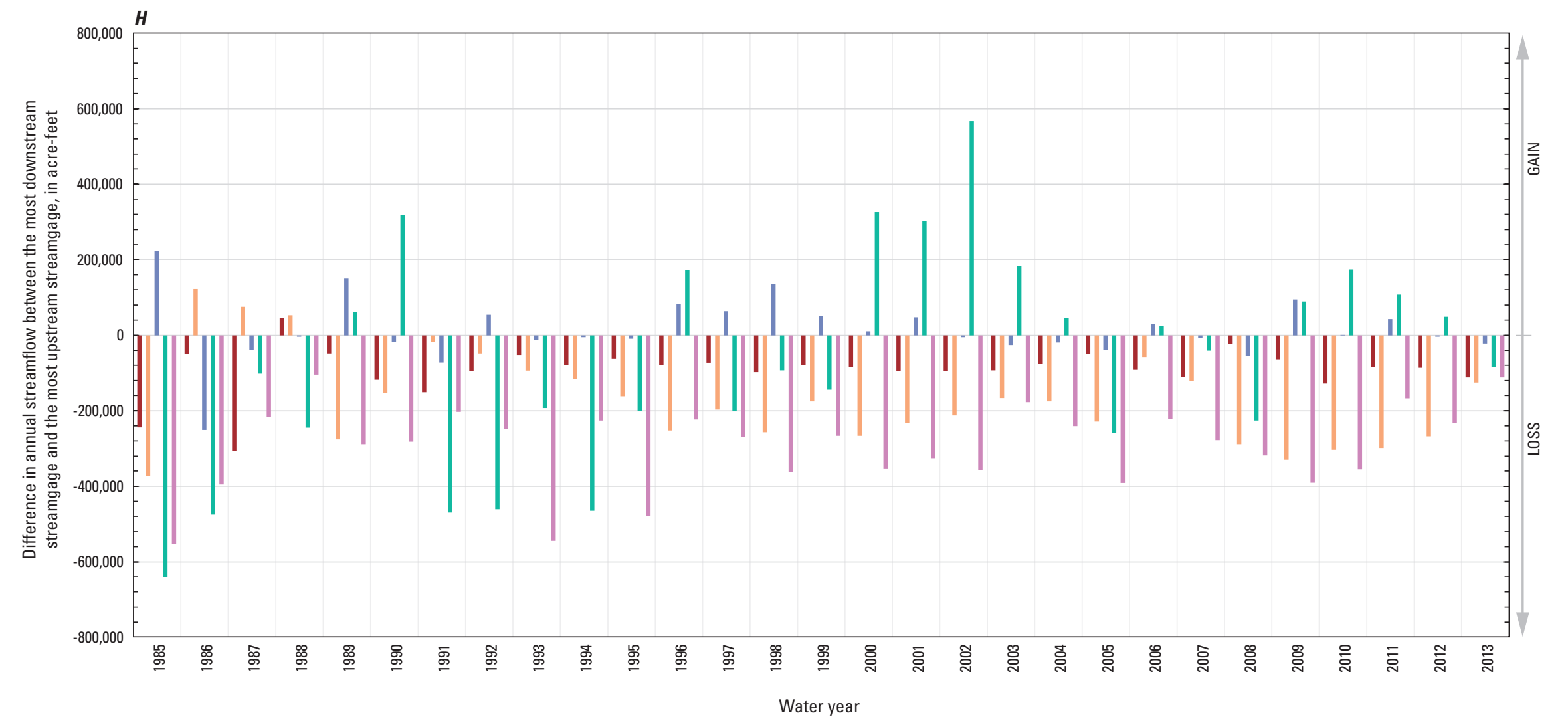

Rio Grande (RG) reach number (annual difference in streamflow)-

Positive average values indicate a gain over that reach

negative average values indicate a loss over that reach

- RG-5 (average -92,431 acre-feet)

- RG-6 (average -170,562 acre-feet)

RG-7 (average +13,893 acre-feet)

RG-8 (average $-64,838$ acre-feet)

[ RG-9 (average -295,975 acre-feet)

Figure 3. Annual streamflow, departure of annual streamflow from mean annual streamflow, and annual difference in streamflow for streams in the Rio Grande Basin in the sixbasin study area, New Mexico and parts of bordering States and Mexico, water years 1985-2013.-Continued

$H$, Rio Grande annual difference in streamflow by reach, $R G-5$ to $R G-9$. 


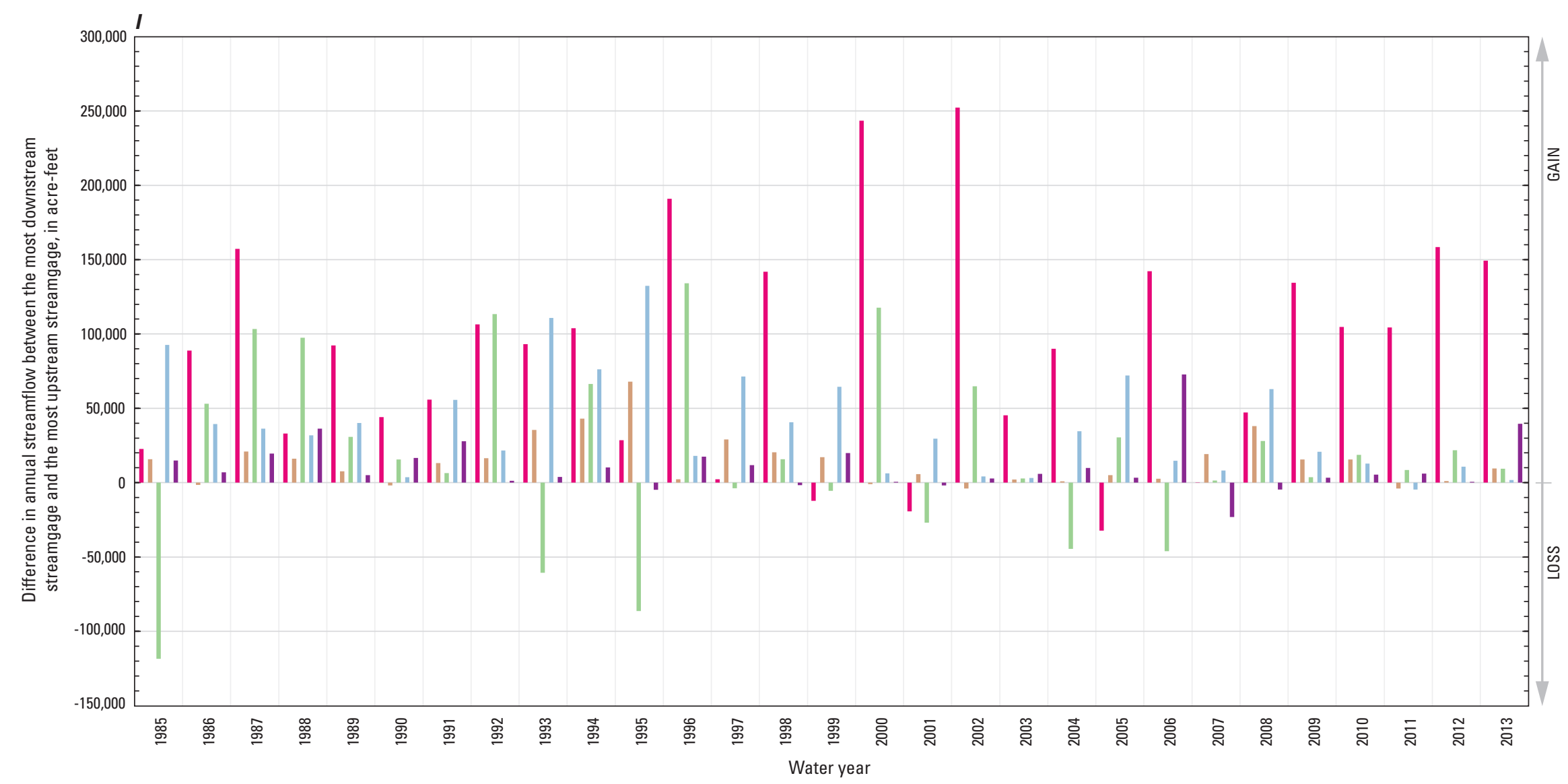

\section{EXPLANATION}

Rio Chama (RC) or Rio Puerco (RP) reach numbe

(annual difference in streamflow)-Positive

average values indicate a gain over that reach

- RC-1 (average $+88,572$ acre-feet)

RC-2 (average $+14,079$ acre-feet)

RC-3 (average $+19,007$ acre-feet)

RC-4 (average $+38,366$ acre-feet)

- RP-1 (average $+10,537$ acre-feet)

Figure 3. Annual streamflow, departure of annual streamflow from mean annual streamflow, and annual difference in streamflow for streams in the Rio Grande Basin in the sixbasin study area, New Mexico and parts of bordering States and Mexico, water years 1985-2013._Continued

I, Rio Grande Basin tributary annual difference in streamflow by reach. 
The greatest positive departure from mean annual streamflow occurred during 1985-87; the departure became negative for 1988-90 (fig. 3C). In 1991, the departures from mean annual streamflow became positive and increased in magnitude until 1995. In 1996, departures from mean annual streamflow were negative, but from 1997 to 1999 the departures were just above the mean. For 2000-13, departures from mean annual streamflow were, for the most part, negative except for 2005 and 2008 (fig. 3C).

Mean annual streamflows in the Rio Grande for the study period increased in magnitude downstream to a high of $1,042,055$ acre-ft at the Rio Grande at Otowi Bridge, N. Mex. (08313000), streamgage but, in general, decreased downstream from this location, reaching a low of 432,142 acre-ft at the Rio Grande at El Paso, Tex. (08364000), streamgage (table 3). The Rio Grande at Otowi Bridge, N. Mex. (08313000), streamgage consistently recorded the highest flow on the river, due in part to the large flow contributed by the Rio Chama upstream from that streamgage (fig. $3 A$; table 3 ).

\section{Red River}

The Red River is one of the shorter tributaries to the Rio Grande and is the northernmost tributary that is entirely within New Mexico (fig. 2). Only one streamgage on the Red River, the Red River below Fish Hatchery, near Questa, N. Mex. (08266820), streamgage (fig. 2), had data for the entire study period, so gains and losses were not computed for this stream. The Red River mean annual streamflow at the Red River below Fish Hatchery, near Questa, N. Mex. (08266820), streamgage for the study period was 53,266 acre-ft, indicating that this stream was the second largest tributary to the Rio Grande (table 4). During the study period, the highest annual flow, 85,850 acre-ft, occurred in 1995, and the lowest annual flow, 24,530 acre-ft, occurred in 2002 (fig. 3D; table 4). Departures from mean annual streamflow generally were positive for 1985-87, 1991-95, and 2008-09 and generally were negative during the rest of the study period (fig. $3 E$ ).

\section{Rio Hondo}

The Rio Hondo is located directly south of the Red River (fig. 2). Only one streamgage on the Rio Hondo, the Rio Hondo near Valdez, N. Mex. (08267500), streamgage (fig. 2), had data for the entire study period, so gains and losses were not computed for this stream. Annual flows at the Rio Hondo near Valdez, N. Mex. (08267500), streamgage were of lesser magnitude than the Red River but had a similar pattern of departure from the mean annual streamflow as the Red River (figs. $3 D$ and $3 E$; table 4 ). Mean annual streamflow at the Rio Hondo near Valdez, N. Mex. (08267500), streamgage for the study period was 24,489 acre- $\mathrm{ft}$, indicating that this stream was the fourth largest tributary to the Rio Grande (fig. 3D; table 4). Similar to the Red River, the Rio Hondo had its highest annual flow, 45,880 acre-ft, in 1995 and its lowest annual flow, 7,240 acre-ft, in 2002 (fig. 3D; table 4).

\section{Rio Pueblo de Taos}

The Rio Pueblo de Taos is located directly south of the Rio Hondo (fig. 2). Only one streamgage on the Rio Pueblo de Taos, the Rio Pueblo de Taos near Taos, N. Mex. (08269000), streamgage (fig. 2), had data for the entire study period, so gains and losses were not computed for this stream. The mean annual streamflow at the Rio Pueblo de Taos near Taos, N. Mex. (08269000), streamgage was 19,422 acre-ft, indicating that this stream was the sixth largest (and therefore the smallest) tributary to the Rio Grande (table 4). Similar to flows in the Red River and Rio Hondo, departure from mean annual streamflow generally was positive for 1985-87, 1991-95, and 2008-09 and generally was negative during the rest of the study period (fig. $3 E$ ). Like the Red River and Rio Hondo, the highest annual streamflow at the Rio Pueblo de Taos near Taos, N. Mex. (08269000), streamgage was in 1995 at 41,340 acre-ft, and its lowest annual streamflow was in 2002 at 3,850 acre-ft (fig. $3 D$; table 4).

\section{Rio Chama}

The Rio Chama originates in Colorado and joins the Rio Grande in northern New Mexico (fig. 2). In addition to water from its natural headwater area, the Rio Chama receives water that is diverted from streams in the San Juan River Basin and transferred to the Rio Chama by way of man-made conveyances. There are two reservoirs, El Vado and Abiquiu, on the Rio Chama and a third, Heron (which stores and releases the water transferred from the San Juan River Basin), on a small tributary to the Rio Chama (fig. 2).

Five streamgages on the Rio Chama included in this study are the Rio Chama near La Puente, N. Mex. (08284100), the Rio Chama below El Vado Dam, N. Mex. (08285500), the Rio Chama above Abiquiu Reservoir, N. Mex. (08286500), the Rio Chama below Abiquiu Dam, N. Mex. (08287000), and the Rio Chama near Chamita, N. Mex. (08290000), streamgages (fig. 2). The Rio Chama is the largest tributary to the Rio Grande (table 4). Monthly data for these streamgages on the Rio Chama are presented in appendix 4 . The data indicate an overall pattern of decreasing annual streamflow since 1985 (fig. $3 F$; table 4). Except at the Rio Chama near La Puente, N. Mex. (08284100), streamgage and the Rio Chama below Abiquiu Dam, N. Mex. (08287000), streamgage, the lowest flows occurred in 1990 (fig. $3 F$; table 4$)$.

Mean annual streamflow in the Rio Chama generally increased downstream over the study period (table 4). For 1985-95, only 1988-90 had negative departures from mean annual streamflow (fig. 3E). After 1995, negative departures from the mean became more frequent.

\section{Jemez River}

The Jemez River originates in the Jemez Mountains, N. Mex. (fig. 1), and flows southeast to the Rio Grande (fig. 2). Jemez Canyon Reservoir is located downstream from the study 
streamgage. Only one streamgage on the Jemez River, the Jemez River near Jemez, N. Mex. (08324000), streamgage (fig. 2), had data for the entire study period, so gains and losses were not computed for this stream. Annual flows at the Jemez River near Jemez, N. Mex. (08324000), streamgage generally decreased after 1995 (fig. 3D; table 4). The highest annual flow, 126,700 acre-ft, occurred in 1985, and the lowest flow, 16,010 acre-ft, occurred in 2002 (fig. 3D); the mean annual streamflow at the Jemez River near Jemez, N. Mex. (08324000), streamgage was 52,310 acre-ft, indicating that this stream was the third largest tributary to the Rio Grande (table 4).

\section{Rio Puerco}

The Rio Puerco originates east of the Jemez Mountains (fig. 1) and flows southeast to the Rio Grande between Belen, N. Mex., and Socorro (fig. 2). Two streamgages on the Rio Puerco, the Rio Puerco above Arroyo Chico near Guadalupe, N. Mex. (08334000), streamgage and the Rio Puerco near Bernardo, N. Mex. (08353000), streamgage (fig. 2 ), were identified for inclusion in this study. Annual flows in the Rio Puerco at both streamgages generally decreased after 2000 (fig. 3D; table 4). Annual flows at the Rio Puerco above Arroyo Chico near Guadalupe, N. Mex. (08334000), streamgage decreased gradually over the study period but had high annual flows in 2007-08. Annual flows at the Rio Puerco above Arroyo Chico near Guadalupe, N. Mex. (08334000), streamgage ranged from a high of 34,000 acre-ft in 2007 to a low of 300 acre-ft in 2011, and the mean annual streamflow was 10,503 acre-ft (fig. 3D; table 4). Annual flows at the Rio Puerco near Bernardo, N. Mex. (08353000), streamgage showed a greater decrease over the years than at the Rio Puerco above Arroyo Chico near Guadalupe, N. Mex. (08334000), streamgage but exhibited high annual flows in 2006 and 2013. Annual flows at the Rio Puerco near Bernardo, N. Mex. (08353000), streamgage ranged from a high of 77,300 acre-ft in 2006 to a low of 3,490 acre-ft in 2000 and had a mean annual streamflow of 21,040 acre-ft, indicating that this stream was the fifth largest tributary to the Rio Grande (fig. $3 D$; table 4).

\section{Rio Grande Basin Gains and Losses}

\section{Rio Grande}

Reaches RG-1 through RG-4 (fig. 2) were all gaining reaches except for reach RG-1 in 1986, with no data for RG-1 and RG-2 in 1995 (fig. 3G; table 3). For the study period, mean annual streamflow gains were 28,926 acre-ft for reach RG-1; 179,641 acre-ft for reach RG-2; 53,407 acre-ft for reach RG-3; and 453,590 acre-ft for reach RG-4 (table 3). For the reaches farther downstream (fig. 2), at reach $\mathrm{RG}-5$, the river became a losing stream through reach RG-9, except for reach $\mathrm{RG}-7$, which was a gaining reach (fig. $3 H$; table 3 ).

Reach RG-5 includes Cochiti Lake (fig. 2). Gains and losses for reach RG-5 ranged from a gain of 45,100 acre- $\mathrm{ft}$ in 1988 to a loss of 306,000 acre-ft in 1987, with a mean annual loss of 92,431 acre- $\mathrm{ft}$ over the study period (fig. $3 \mathrm{H}$; table 3). Gains and losses for reach RG-6 ranged from a gain of 122,000 acre-ft in 1986 to a loss of 373,000 acre-ft in 1985, with a mean annual loss of 170,562 acre-ft over the study period (fig. $3 H$; table 3 ). Reach RG-7 had 13 gaining years interspersed with losing years (fig. $3 H$; table 3 ). Gains and losses ranged from a gain of 224,000 acre-ft in 1985 to a loss of 251,000 acre-ft in 1986, with a mean annual gain of 13,893 acre-ft over the study period (fig. $3 H$; table 3). Reach RG-8, which includes Elephant Butte Reservoir (fig. 2), had 13 gaining years interspersed with losing years (fig. $3 \mathrm{H}$; table 3 ). Gains and losses ranged from a gain of 567,700 acre- $\mathrm{ft}$ in 2002 to a loss of 641,000 acre- $\mathrm{ft}$ in 1985 , with a mean annual loss of 64,838 acre-ft over the study period (fig. $3 H$; table 3). For the study period, reach RG-9, which includes Caballo Reservoir (fig. 2) and much of the irrigated land in New Mexico, was a losing reach for all years (fig. $3 H$; table 3). Annual losses ranged from 104,600 acre-ft in 1988 to 552,300 acre-ft in 1985 and had a mean annual loss of 295,975 acre-ft over the study period (fig. $3 H$; table 3 ).

\section{Rio Chama}

The Rio Chama reaches (fig. 2) were gaining in most of the 29 years of the study period: reach $\mathrm{RC}-1$ was gaining for 25 years, reach $\mathrm{RC}-2$ was gaining for 24 years, reach $\mathrm{RC}-3$ was gaining for 21 years, and reach $\mathrm{RC}-4$ was gaining for 28 years (fig. 3I; table 4). Reach RC-1, which includes El Vado Reservoir and has San Juan-Chama Project water inflows from Heron Reservoir (fig. 2), had the greatest gains of all reaches in the basin, which ranged from a gain of 252,260 acre-ft in 2002 to a loss of 32,200 acre-ft in 2005 and had a mean annual gain of 88,572 acre-ft (fig. 3I; table 4).

\section{Rio Puerco}

Reach RP-1 (fig. 2) was a gaining reach for 24 years of the study period (fig. 3I; table 4). Annual gains and losses for reach $\mathrm{RP}-1$ ranged from a gain of 72,680 acre-ft in 2006 to a loss of 23,090 acre-ft in 2007, with a mean annual gain of 10,537 acre-ft (fig. 3I; table 4).

\section{Pecos River Basin Streamflow}

\section{Pecos River}

The Pecos River originates in northern New Mexico in the central part of the State, flows down the eastern half of New Mexico, and enters Texas in southeastern New Mexico 
(fig. 4). One tributary to the Pecos River, the Rio Hondo (fig. 4), is included in this report. The Rio Hondo begins at the confluence of the Rio Bonito and the Rio Ruidoso and joins the Pecos River near Roswell, N. Mex. Data for 11 streamgages on the Pecos River, 2 on the Rio Hondo, and 1 on the Rio Ruidoso (fig. 4; table 5) were compiled for this report. Monthly data for these streamgages are presented in appendix 5 .

The Pecos River Basin has many reservoirs and lakes, including Santa Rosa Lake, Lake Sumner, Brantley Lake, Lake Avalon, and Red Bluff Reservoir on the Pecos River, and the Two Rivers Reservoir on the Rio Hondo (fig. 4). The Pecos River below Avalon Dam, N. Mex. (08404000), streamgage had 4 years of little to no flow $(1988,1990$, 2010, and 2012), although flow occurred at the other streamgages (figs. $5 A$ and $5 B$; table 5). The Pecos River above Canon del Uta near Colonias, N. Mex. (08382600), streamgage lacked data for 2008 . There are also substantial irrigation diversions along the Pecos River in New Mexico.

In general, annual streamflow on the Pecos River increased from 1985 to 1995 but decreased from 1995 to 2013 (figs. $5 A$ and $5 B$; table 5). Departures from the mean annual streamflow generally were positive for 1985-2000 and negative for 2001-13 (fig. 5C). The Pecos River near Puerto de Luna, N. Mex. (08383500), streamgage had the highest mean annual streamflow for the Pecos River for the study period with 133,589 acre-ft, with annual streamflow that ranged from 71,610 acre-ft in 2012 to 230,000 acre-ft in 1995. The Pecos River below Avalon Dam, N. Mex. (08404000), streamgage had the lowest mean annual streamflow with 27,362 acre-ft, with annual streamflow that ranged from 0.00 acre-ft in 1988, 2010, and 2012 to 130,800 acre-ft in 1987 (table 5). Highest annual flows at the streamgages upstream from the Pecos River below Sumner Dam, N. Mex. (08384500), streamgage occurred in the 1990s (fig. 5A; table 5), whereas highest annual flows at the streamgages from the Pecos River near Acme, N. Mex. (08386000), streamgage to the Pecos River at Red Bluff, N. Mex. (08407500), streamgage occurred in 1987, except at the Pecos River at Red Bluff, N. Mex. (08407500), streamgage, which had highest annual flow in 1986 (fig. $5 B$; table 5). Periods of the lowest flow on the Pecos River occurred between 2009 and 2013, with some exceptions; the Pecos River near Pecos, N. Mex. (08378500), streamgage and the Pecos River near Anton Chico, N. Mex. (08379500), streamgage had the lowest annual flows in 2002, whereas the Pecos River below Avalon Dam, N. Mex. (08404000), streamgage had 4 years with $0-3.5$ acre-ft and an annual flow of 68 acre-ft in 1989 (figs. $5 A$ and $5 B$; table 5). Mean annual streamflows ranged from 133,589 acre-ft at the Pecos River near Puerto de Luna, N. Mex. (08383500), streamgage to 27,362 acre-ft at the Pecos River below Avalon Dam, N. Mex. (08404000), streamgage (table 5).

\section{Rio Hondo}

The Rio Hondo forms at the confluence of the Rio Ruidoso and Rio Bonito (fig. 4). Although the USGS has operated streamgages on the Rio Bonito in the past, there are no streamgages with a continuous record for the study period. One streamgage on the Rio Ruidoso (Rio Ruidoso at Hollywood, N. Mex. [08387000]) has continuous data for the entire study period. This streamgage on the Rio Ruidoso was used with the Rio Hondo at Diamond A Ranch near Roswell, N. Mex. (08390500), streamgage to create a reach that encompassed the upper Rio Hondo, and flow difference was calculated for this reach. The Rio Hondo has one reservoir, Two Rivers Reservoir (fig. 4). Low annual streamflows generally occurred in 1999-2004, 2009, and 2011-12 (fig. 5D; table 5). The highest annual streamflow at all streamgages occurred in 1987. Annual streamflows generally have decreased in magnitude from 1992 to 2013, but there were moderate flows at some locations during 2006-13. Annual flows at the Rio Ruidoso at Hollywood, N. Mex. (08387000), streamgage ranged from a low of 4,370 acre-ft in 2002 to a high of 35,950 acre-ft in 1987 and had a mean annual streamflow of 15,275 acre-ft (fig. 5D; table 5). Annual flows at the Rio Hondo at Diamond A Ranch near Roswell, N. Mex. (08390500), streamgage ranged from a low of 13 acre-ft in 2003 to a high of 78,570 acre-ft in 1987 and had a mean annual streamflow of 17,390 acre-ft. Annual flows at the Rio Hondo below Diamond A Dam near Roswell, N. Mex. (08390800), streamgage ranged from a low of 0.9 acre-ft in 2000 to a high of 62,000 acre-ft in 1987 and had a mean annual streamflow of 10,427 acre-ft. Both the Rio Hondo at Diamond A Ranch near Roswell, N. Mex. (08390800), streamgage and the Rio Hondo below Diamond A Dam near Roswell, N. Mex. (08390800), streamgage showed notably low flows from 1999 to 2003 (fig. 5D; table 5). Departures from the mean annual streamflow generally were negative after 2000 (fig. 5C).

\section{Pecos River Basin Gains and Losses}

\section{Pecos River}

The Pecos River was divided into 10 reaches (fig. 4), which varied greatly in terms of annual gains and losses (figs. $5 E$ and $5 F$; table 5). The first reach, PEC-1, had gains in 18 of 29 years. Gains and losses ranged from a gain of 57,400 acre-ft in 1991 to a loss of 21,650 acre-ft in 2012 (fig. $5 E$; table 5). Reach PEC -2 had losses in 25 of 28 years. Annual gains and losses ranged from a gain of 34,380 acre-ft in 2013 to a loss of 43,700 acre-ft in 1997. Reach PEC-3 had gains in 26 of 28 years. Annual gains and losses ranged from a gain of 36,460 acre-ft in 1999 to a loss of 15,040 acre-ft in 2004. Reach PEC-4 had losses in 17 of 29 years. Annual gains and losses ranged from a gain of 79,200 acre-ft in 2000 to a loss of 95,640 acre-ft in 2013. 


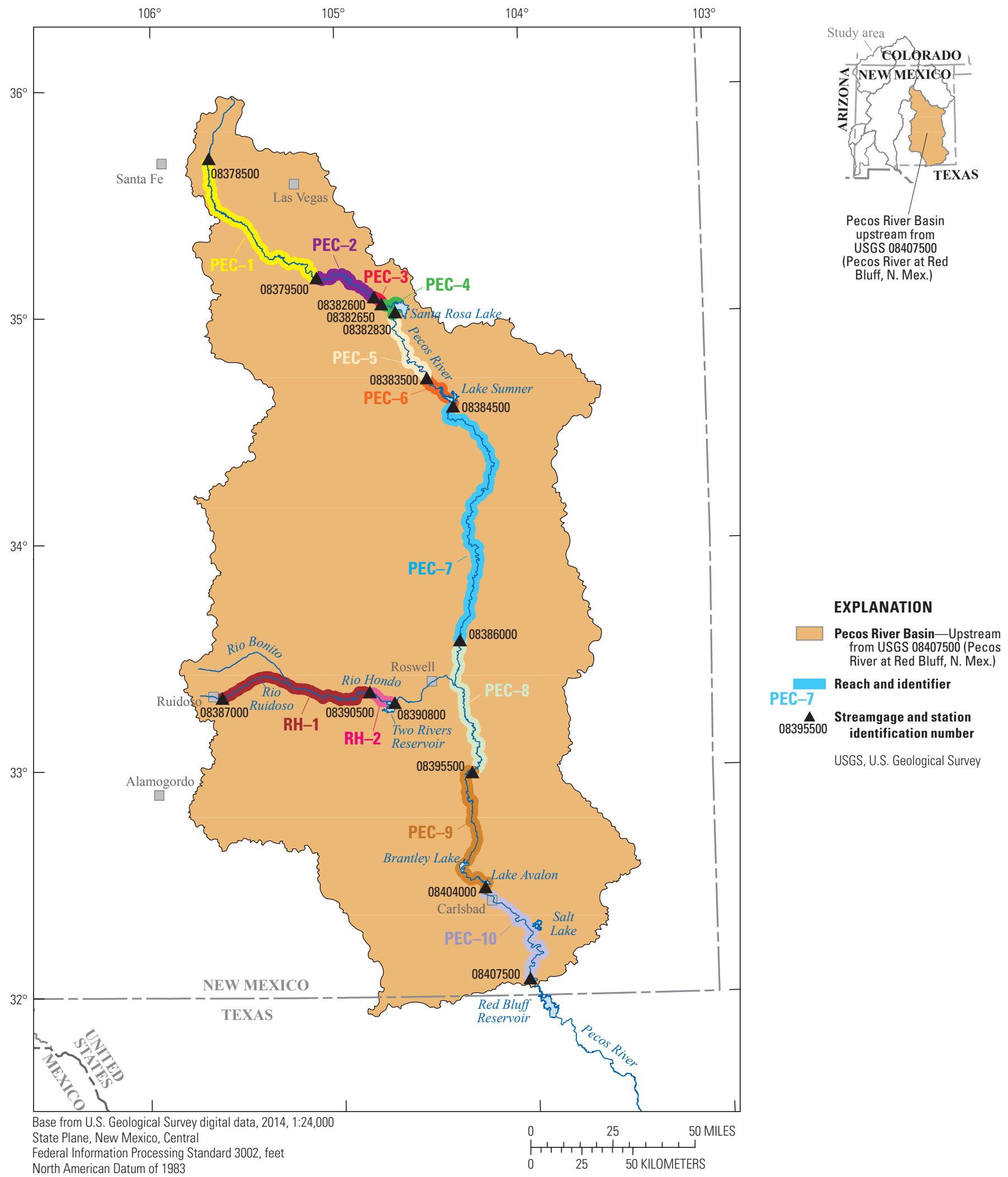

Figure 4. Pecos River Basin, streams, stream reaches, and streamgages upstream from the Pecos River at Red Bluff, New Mexico (08407500), streamgage in the six-basin study area, New Mexico and parts of bordering States and Mexico. 
Table 5. Annual streamflow and annual difference in streamflow by reach for selected Pecos River Basin streamgages in the six-basin study area, New Mexico and parts of bordering States and Mexico, water years 1985-2013.

[N. Mex., New Mexico; acre-ft, acre-feet; --, no data; PEC, Pecos River reach, numbered in downstream order; RH, Rio Hondo reach, numbered in downstream order]

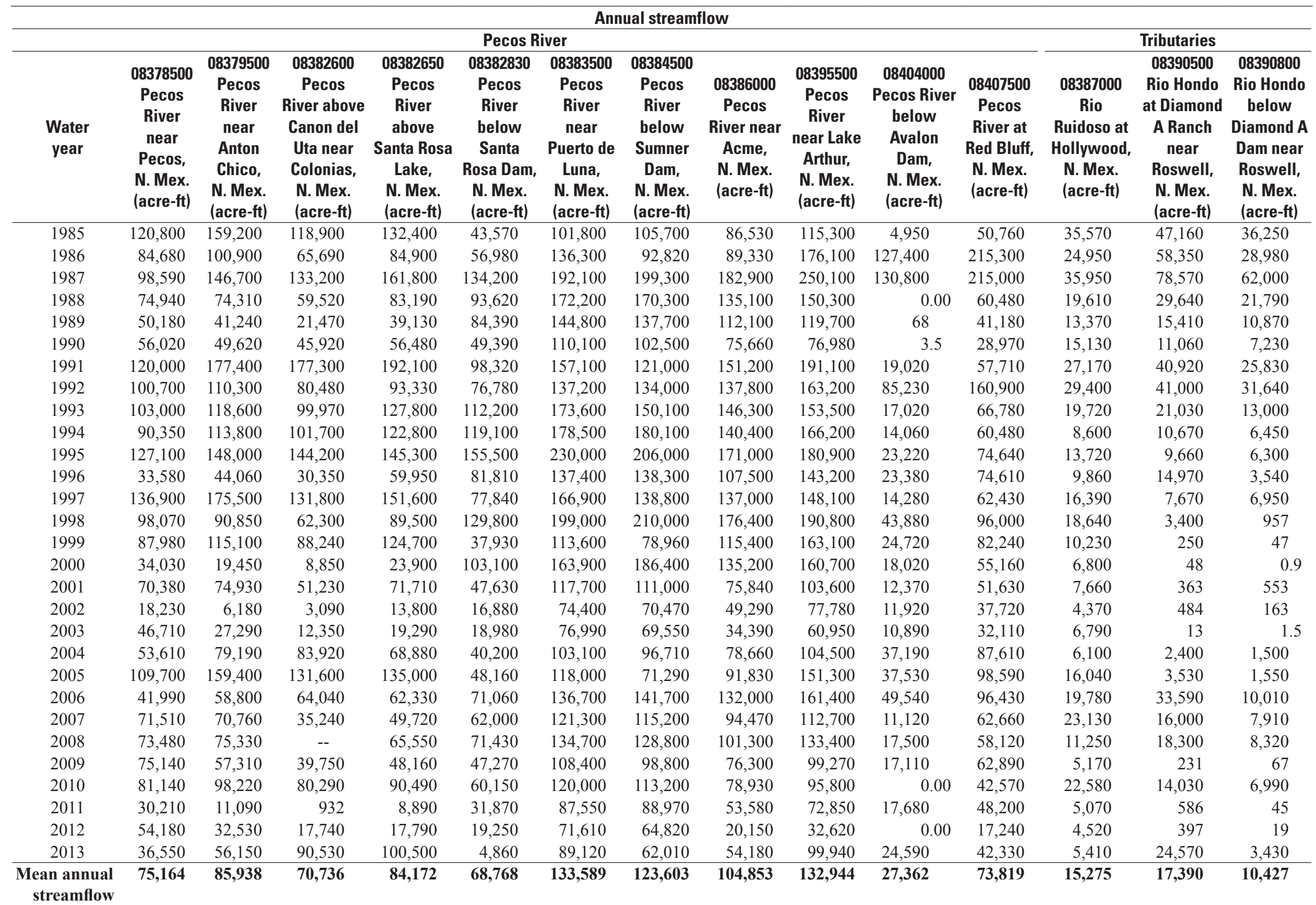


Table 5. Annual streamflow and annual difference in streamflow by reach for selected Pecos River Basin streamgages in the six-basin study area, New Mexico and parts of bordering States and Mexico, water years 1985-2013.-Continued

[N. Mex., New Mexico; acre-ft, acre-feet; --, no data; PEC, Pecos River reach, numbered in downstream order; RH, Rio Hondo reach, numbered in downstream order]

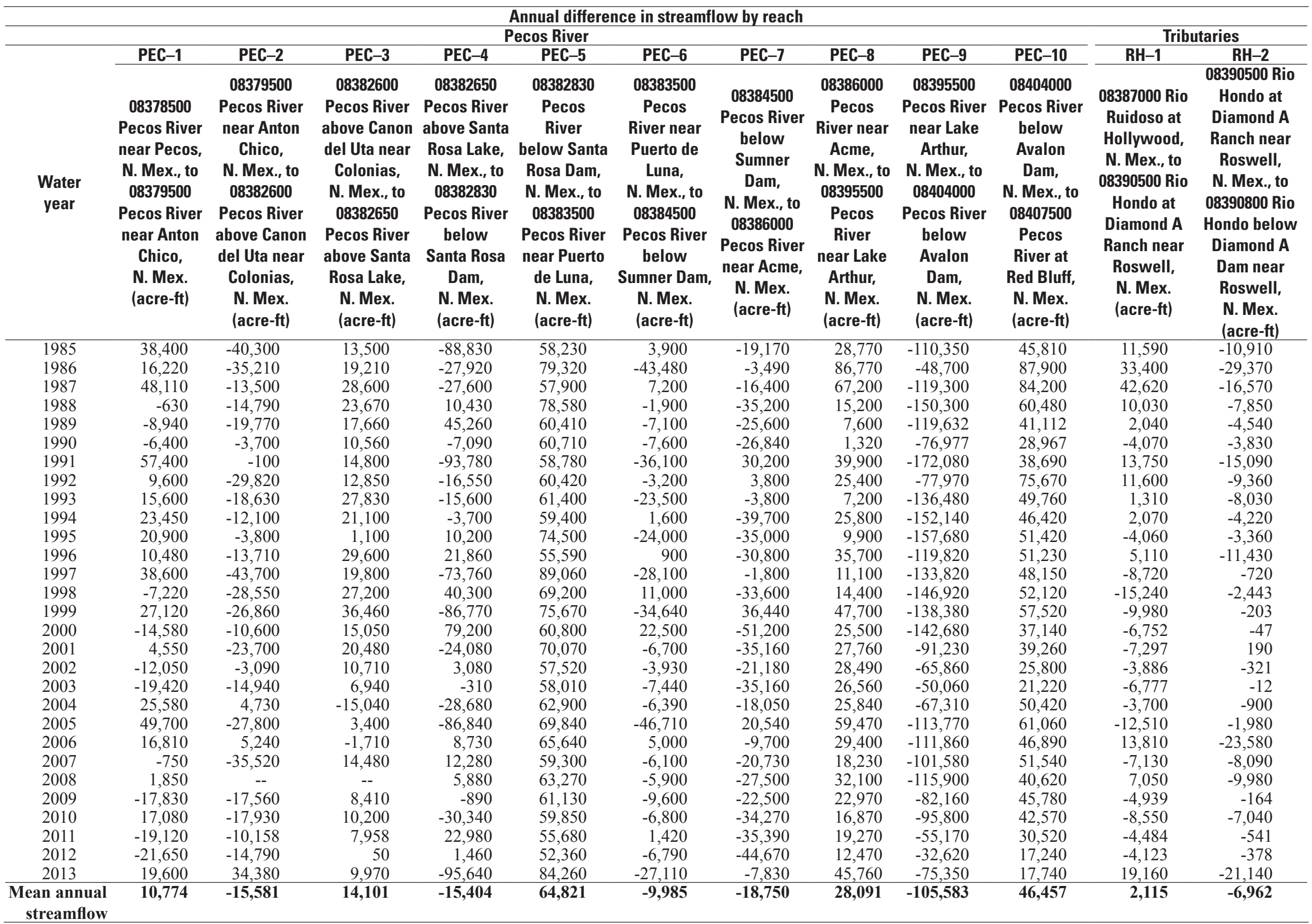




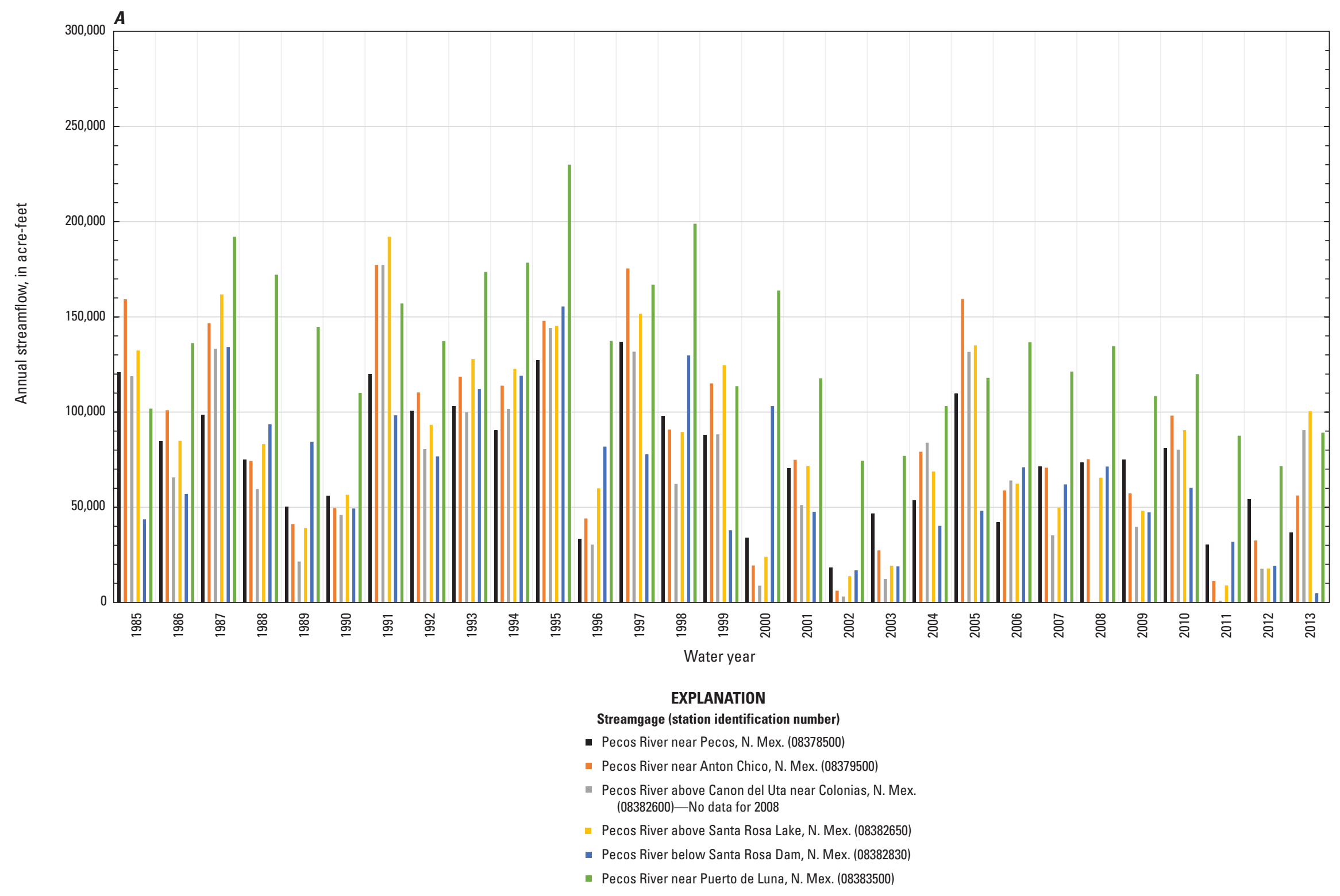

Figure 5. Annual streamflow, departure of annual streamflow from mean annual streamflow, and annual difference in streamflow for streams in the Pecos River Basin in the six-basin study area, New Mexico and parts of bordering States and Mexico, water years 1985-2013.

$A$, Pecos River annual streamflow by streamgage, in downstream order, upstream from the Pecos River near Puerto de Luna, N. Mex. (08383500), streamgage. 


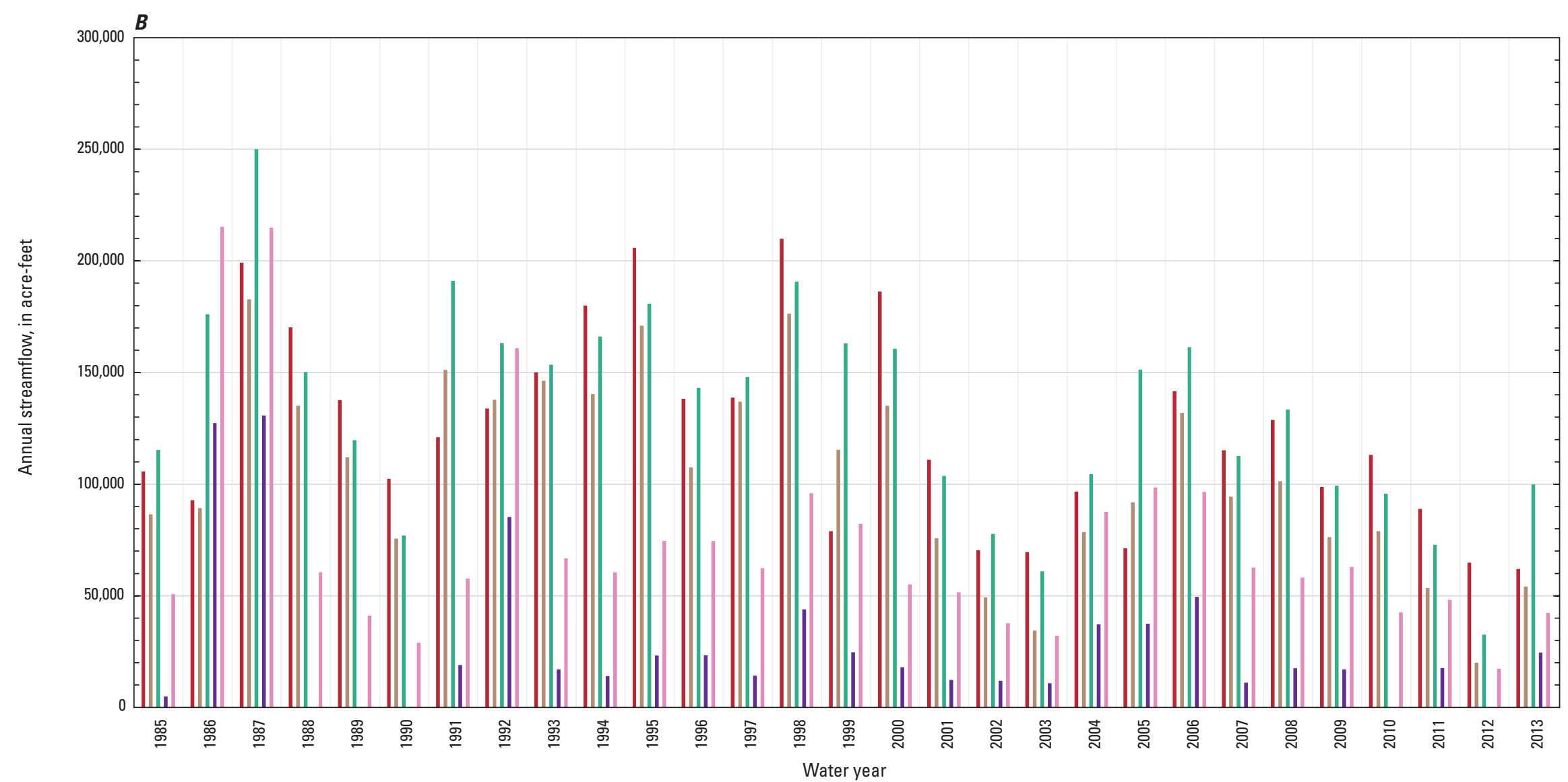

\section{EXPLANATION}

Streamgage (station identification number)

- Pecos River below Sumner Dam, N. Mex. (08384500)

- Pecos River near Acme, N. Mex. (08386000)

- Pecos River near Lake Arthur, N. Mex. (08395500)

- Pecos River below Avalon Dam, N. Mex. $(08404000$

- Pecos River at Red Bluff, N. Mex. (08407500)

Figure 5. Annual streamflow, departure of annual streamflow from mean annual streamflow, and annual difference in streamflow for streams in the Pecos River Basin in the six-basin study area, New Mexico and parts of bordering States and Mexico, water years 1985-2013.-Continued

$B$, Pecos River annual streamflow by streamgage, in downstream order, from the Pecos River below Sumner Dam, N. Mex. (08384500), streamgage to the Pecos River at Red Bluff, N. Mex. (08407500), streamgage. 


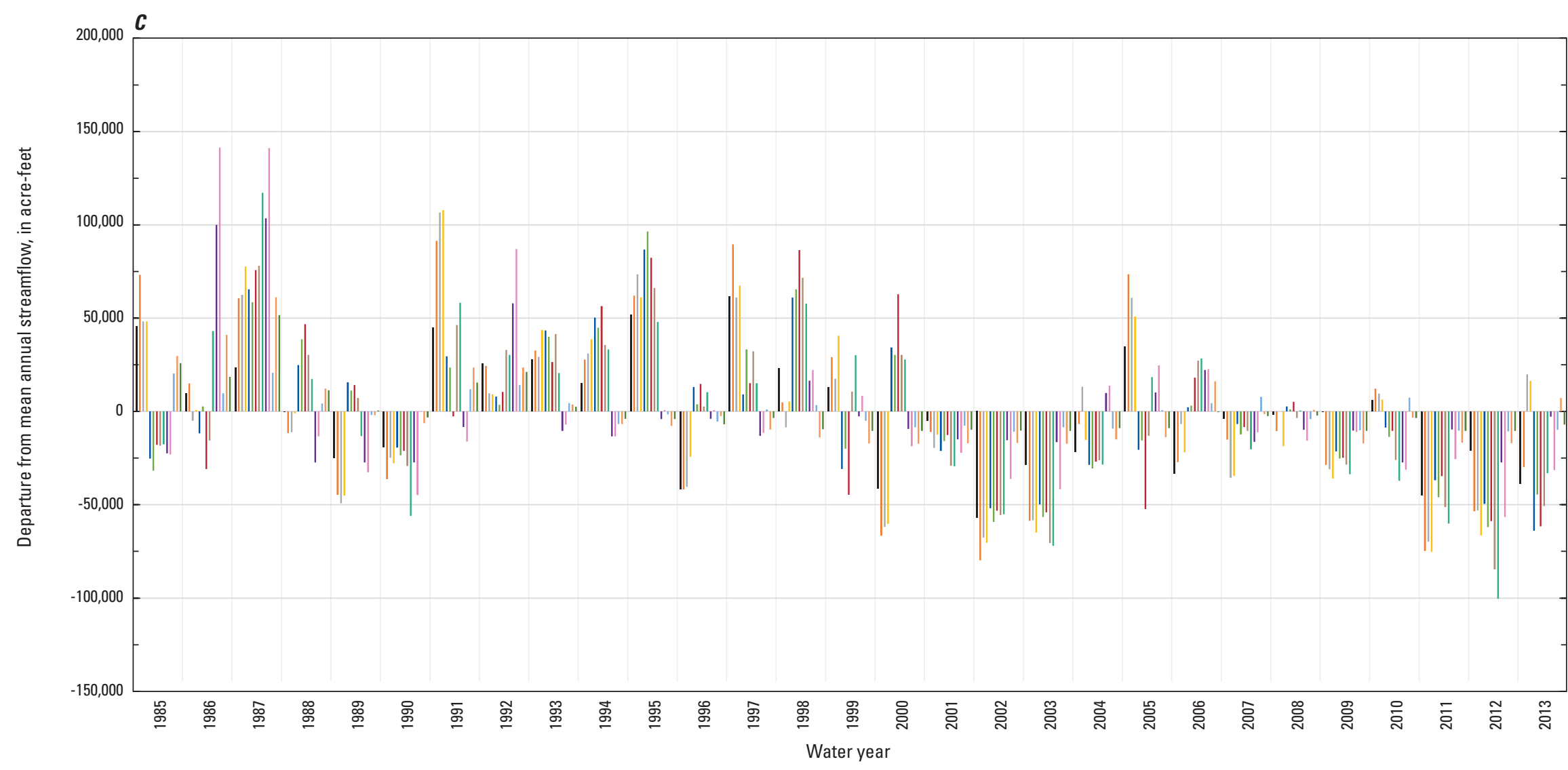

\section{EXPLANATION}

\section{treamgage (station identification number)}

- Pecos River near Pecos, N. Mex. (08378500)

- Pecos River near Anton Chico, N. Mex. (08379500)

Pecos River above Canon del Uta near Colonias, N. Mex. (08382600)—No data for 2008

- Pecos River above Santa Rosa Lake, N. Mex. (08382650)

- Pecos River below Santa Rosa Dam, N. Mex. (08382830)

- Pecos River near Puerto de Luna, N. Mex. (08383500)

- Pecos River below Sumner Dam, N. Mex. (08384500)
- Pecos River near Acme, N. Mex. (08386000)

- Pecos River near Lake Arthur, N. Mex. (08395500)

- Pecos River below Avalon Dam, N. Mex. (08404000)

- Pecos River at Red Bluff, N. Mex. (08407500)

- Rio Ruidoso at Hollywood, N. Mex. (08387000)

- Rio Hondo at Diamond A Ranch near Roswell, N. Mex. (08390500)

- Rio Hondo below Diamond A Dam near Roswell, N. Mex. (08390800)

Figure 5. Annual streamflow, departure of annual streamflow from mean annual streamflow, and annual difference in streamflow for streams in the Pecos River Basin in the six-basin study area, New Mexico and parts of bordering States and Mexico, water years 1985-2013.—Continued

$C$, Departure of annual streamflow from mean annual streamflow at Pecos River and tributary streamgages. 


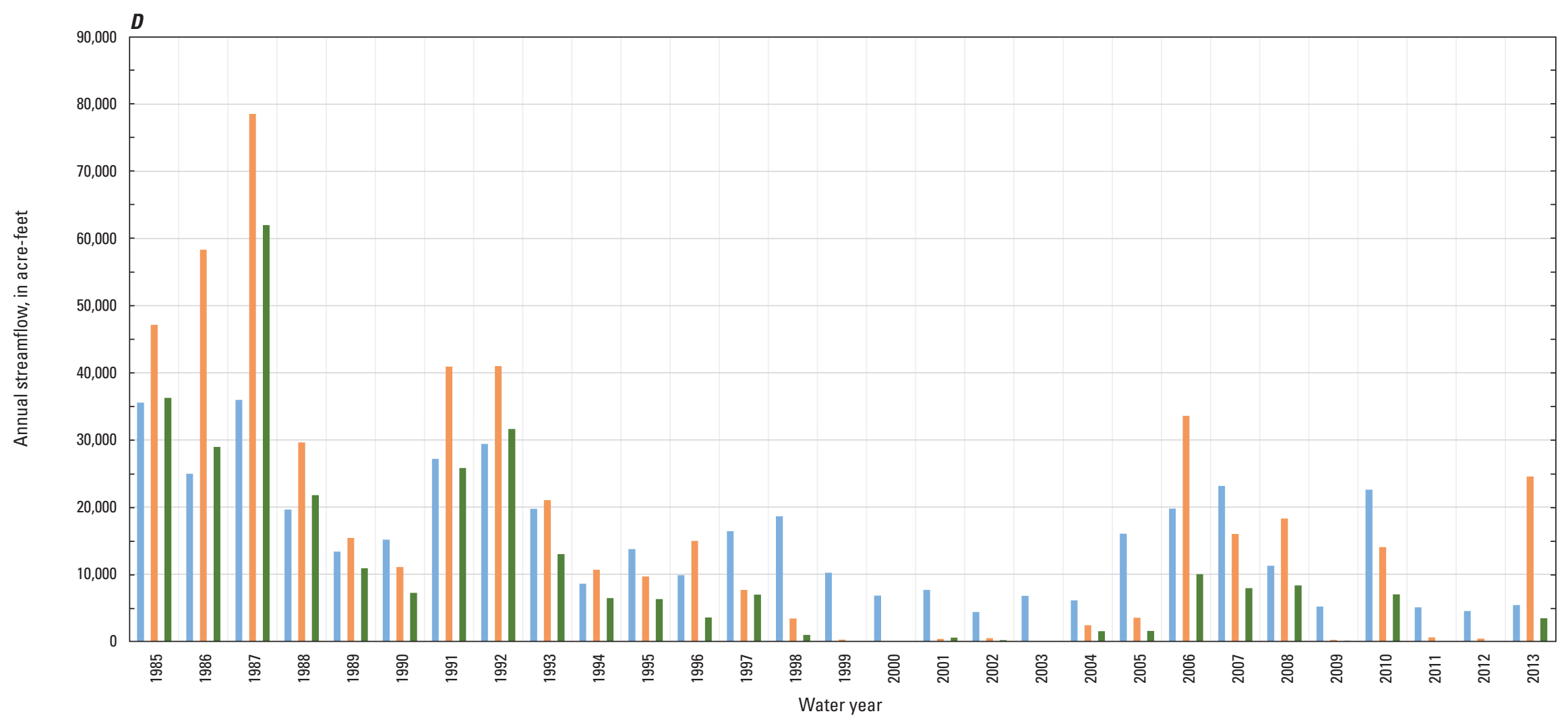

EXPLANATION

Streamgage (station identification number)

- Rio Ruidoso at Hollywood, N. Mex. (08387000)

- Rio Hondo at Diamond A Ranch near Roswell, N. Mex. (08390500)

- Rio Hondo below Diamond A Dam near Roswell, N. Mex. (08390800)

Figure 5. Annual streamflow, departure of annual streamflow from mean annual streamflow, and annual difference in streamflow for streams in the Pecos River Basin in the six-basin study area, New Mexico and parts of bordering States and Mexico, water years 1985-2013.-Continued 


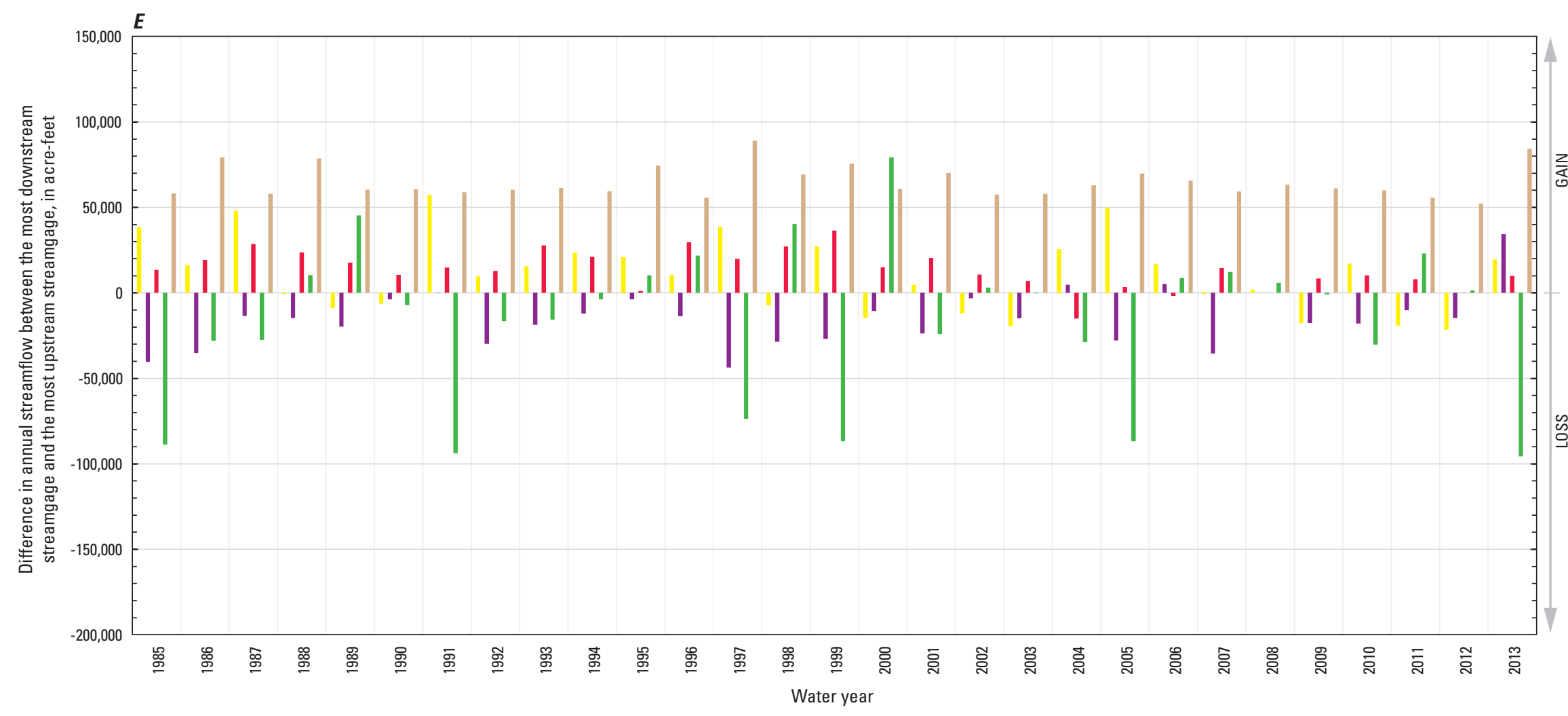

Pecos River ( $\mathrm{PEC}$ ) reach number (annual difference in streamflow)Positive average values indicate a gain over that reach; negative average values indicate a loss over that reach

PEC-1 (average $+10,774$ acre-feet)

- PEC-2 (average -15,581 acre-feet)—No data for 2008

- PEC-3 (average +14,101 acre-feet)—No data for 2008

D PEC-4 (average $-15,404$ acre-feet)

PEC-5 (average $+64,821$ acre-feet)

Figure 5. Annual streamflow, departure of annual streamflow from mean annual streamflow, and annual difference in streamflow for streams in the Pecos River Basin in the six-basin study area, New Mexico and parts of bordering States and Mexico, water years 1985-2013.-Continued

$E$, Pecos River Basin annual difference in streamflow by reach, PEC-1 to PEC-5. 


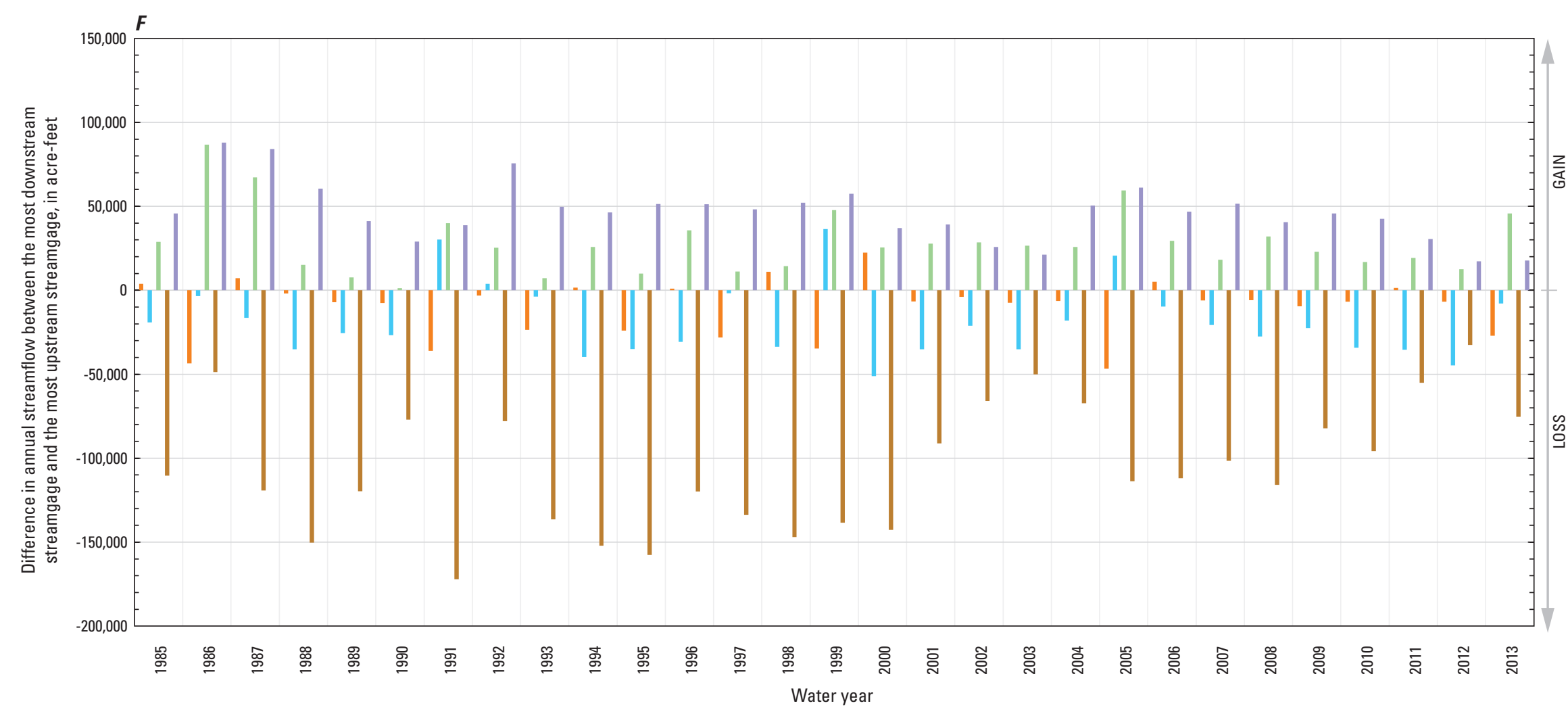

\section{EXPLANATION}

Pecos River (PEC) reach number (annual difference in streamflow)-

Positive average values indicate a gain over that reach;

negative average values indicate a loss over that reach

I. PEC-6 (average $-9,985$ acre-feet)

PEC-7 (average $-18,750$ acre-feet)

(1- PEC-8 (average $+28,091$ acre-feet)

- PEC-9 (average - 105,583 acre-feet)

I PEC-10 (average $+46,457$ acre-feet)

Figure 5. Annual streamflow, departure of annual streamflow from mean annual streamflow, and annual difference in streamflow for streams in the Pecos River Basin in the six-basin study area, New Mexico and parts of bordering States and Mexico, water years 1985-2013.—Continued

$F$, Pecos River Basin annual difference in streamflow by reach, PEC-6 to PEC-10. 


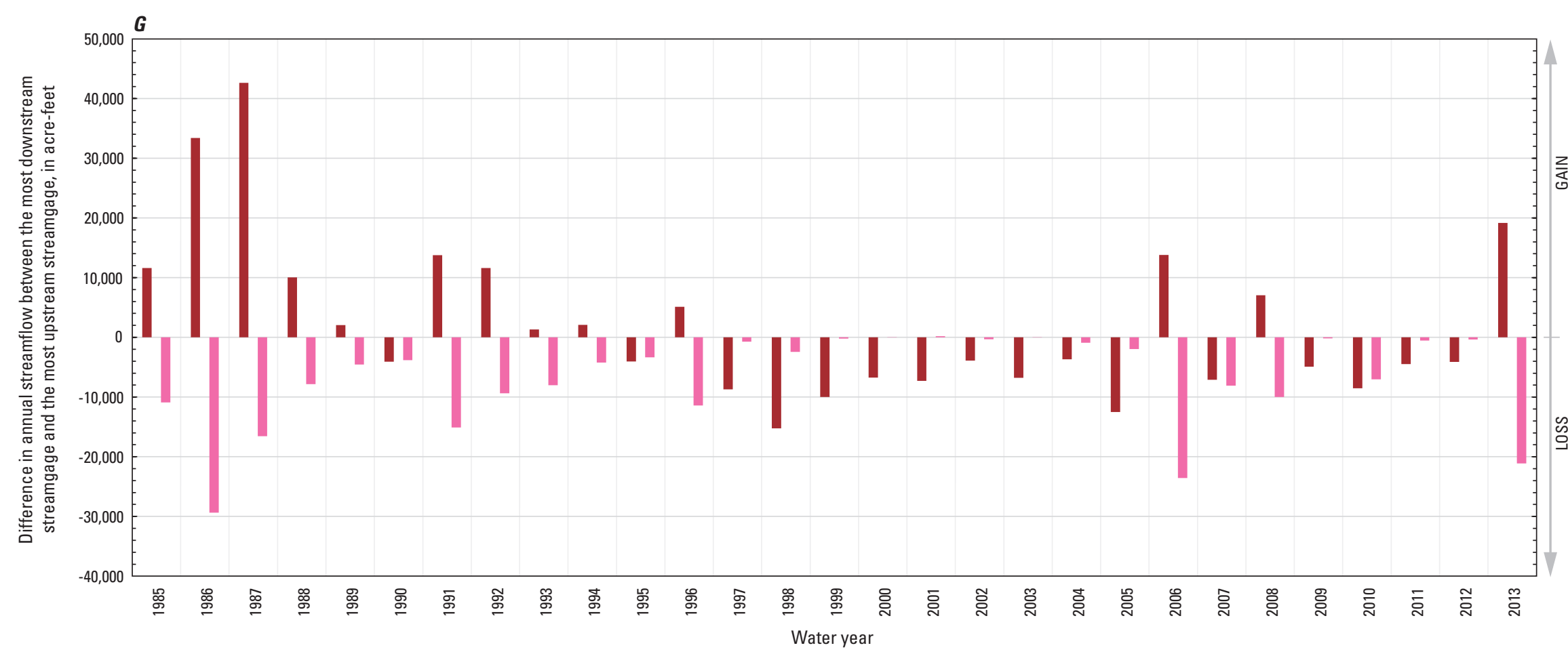

Rio Hondo (RH) reach Positive average values indicate a gain over that reach; negative average values indicate a loss over that reach

- $\mathrm{RH}-1$ (average $+2,115$ acre-feet)

- $\mathrm{RH}-2$ (average $-6,962$ acre-feet)

Figure 5. Annual streamflow, departure of annual streamflow from mean annual streamflow, and annual difference in streamflow for streams in the Pecos River Basin in the six-basin study area, New Mexico and parts of bordering States and Mexico, water years 1985-2013.-Continued

$G$, Pecos River Basin tributary annual difference in streamflow by reach. 
Reach PEC-5 had gains in all 29 years, which ranged from 52,360 acre-ft in 2012 to 89,060 acre-ft in 1997, and had the highest mean annual gain for the study period, 64,821 acre-ft (fig. 5E; table 5). Reach PEC-6 had losses in 21 of 29 years. Annual gains and losses ranged from a gain of 22,500 acre-ft in 2000 to a loss of 46,710 acre-ft in 2005 (fig. $5 F$; table 5).

Reach PEC -7 had losses in 25 of 29 years. Annual gains and losses ranged from a gain of 36,440 acre-ft in 1999 to a loss of 51,200 acre-ft in 2000. Reach PEC-8 had gains in all 29 years, which ranged from 1,320 acre- $\mathrm{ft}$ in 1990 to 86,770 acre- $\mathrm{ft}$ in 1986 (fig. 5F; table 5). The Rio Hondo joins the Pecos River in reach PEC-8 and contributes to the streamflow gains in the Pecos River. Reach PEC-9 had losses in all 29 years, which ranged from 32,620 acre-ft in 2012 to 172,080 acre-ft in 1991, and had the greatest mean annual loss for the study period, 105,583 acre-ft. Reach PEC-10 had gains in 29 years, which ranged from a low of 17,240 acre-ft in 2012 to a high 87,900 acre-ft in 1986 (fig. 5F; table 5).

The Pecos River does not have inflow to the State since it originates in New Mexico (fig. 4). A gain/loss computation was not done for the entirety of the stream, but the Pecos River contributed a mean annual outflow of 73,819 acre-ft and a total outflow of 2,140,740 acre-ft from 1985 to 2013 (table 2).

\section{Rio Hondo}

Reach RH-1 (fig. 4) was a losing reach for 16 years of the study, with annual gains early in the study period. The magnitude of the gains decreased over time, and reach RH-1 ultimately became a losing reach with periodic gaining years. Annual gains and losses in reach $\mathrm{RH}-1$ ranged from a 42,620 acre-ft gain in 1987 to a 15,240 acre-ft loss in 1998. Reach RH-2 (fig. 4) was a losing reach for 28 years over the study period. Annual gains and losses for reach RH-2 ranged from a gain of 190 acre-ft in 2001 to a loss of 29,370 acre-ft in 1986 (fig. 5G; table 5).

\section{San Juan River Basin Streamflow}

\section{San Juan River}

The San Juan River originates in southern Colorado, flows through the northwestern corner of New Mexico, and exits the State near the Four Corners area (fig. 6). Navajo Reservoir, located between the San Juan River near Carracas, Colo. (09346400), and San Juan River near Archuleta, N. Mex. (09355500), streamgages, is a major hydrologic feature on the San Juan River (fig. 6). In addition to four streamgages on the San Juan River, data were compiled for four streamgages on two tributaries to the San Juan River: two on the Animas River and two on the La Plata River (fig. 6). The Animas and La Plata Rivers both join the San Juan
River between the San Juan River near Archuleta, N. Mex. (09355500), and the San Juan River at Shiprock, N. Mex. (09368000), streamgages near Farmington (fig. 6). Monthly values for these streamgages for the period of record are presented in appendix 6.

Over the study period, the San Juan River had some of the highest flows of any river in New Mexico, and flow on the river generally increased in the downstream direction (fig. $7 A$; tables 2 and 6). The mean annual streamflow at the San Juan River near Carracas, Colo. (09346400), streamgage was 424,117 acre- $\mathrm{ft}$, and annual flow ranged from 81,100 acre- $\mathrm{ft}$ in 2002 to 869,300 acre-ft in 1985 (fig. $7 A$; table 6). The mean annual streamflow at the San Juan River near Archuleta, N. Mex. (09355500), streamgage was 746,800 acre-ft, and annual flow ranged from 282,400 acre- $\mathrm{ft}$ in 2004 to 1,945,000 acre-ft in 1987. The mean annual streamflow at the San Juan River at Shiprock, N. Mex. (09368000), streamgage was $1,270,448$ acre-ft, and annual flow ranged from 475,400 acre-ft in 2002 to 2,915,000 acre-ft in 1987. The mean annual streamflow at the San Juan River at Four Corners, Colo. (09371010), streamgage was 1,343,062 acre-ft, and annual flow ranged from 534,700 acre-ft in 2002 to 3,026,000 acre-ft in 1987 (fig. 7A; table 6).

Departures from mean annual streamflow were positive from 1985 to 1987 and peaked in 1987 (fig. 7B). Departures generally were negative for 1988-91 and were variable for 1992-99. From 2000 to 2013, departures from the mean annual streamflow were predominantly negative; positive departures occurred for some or all streamgages in 2001, 2005, 2007, and 2008.

\section{Animas River}

The Animas River originates in Colorado, flows south into New Mexico, and joins the San Juan River at Farmington (fig. 6). The streamgages selected for this study were the Animas River near Cedar Hill, N. Mex. (09363500), streamgage and the Animas River at Farmington, N. Mex. (09364500), streamgage. Annual flow at the Animas River at Farmington, N. Mex. (09364500), streamgage, representing flow into the San Juan River, generally was less than the annual inflow to the State, measured at the Animas River at Cedar Hill, N. Mex. (09363500), streamgage, except for 1987 and 1997 (fig. 7A; table 6). Streamflow on the Animas River was highly variable year to year but, after 1999, generally tended to decrease (fig. $7 \mathrm{~A}$; table 6). Over the study period, annual flows at the Animas River near Cedar Hill, N. Mex. (09363500), streamgage ranged from 193,700 acre-ft in 2002 to $1,048,000$ acre-ft in 1997, with a mean annual streamflow of 643,359 acre-ft. Annual flows at the Animas River at Farmington, N. Mex. (09364500), streamgage ranged from 128,300 acre-ft in 2002 to $1,059,000$ acre-ft in 1997, with a mean annual streamflow of 587,372 acre-ft (fig. $7 A$; table 6). 

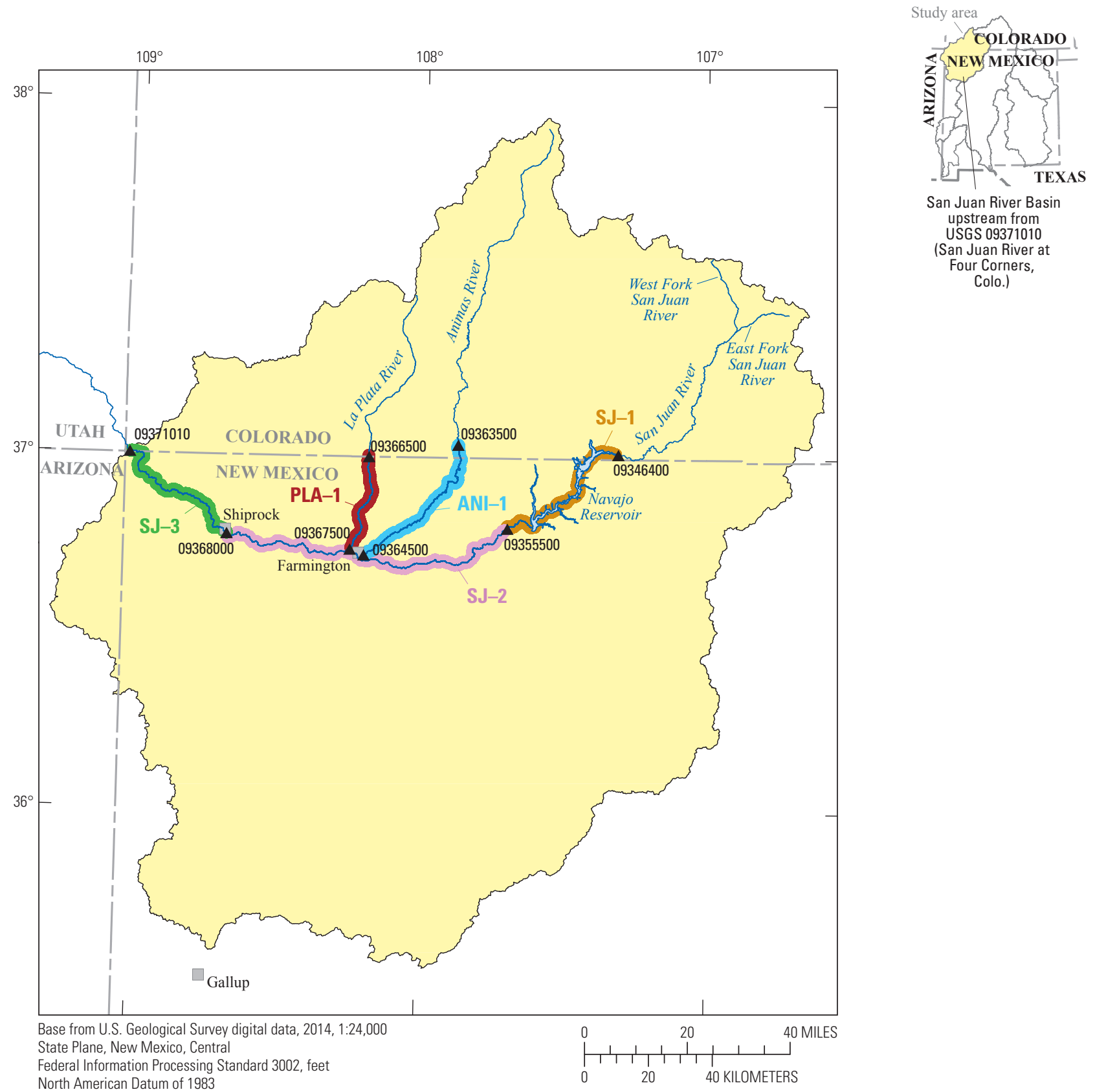

\section{EXPLANATION}

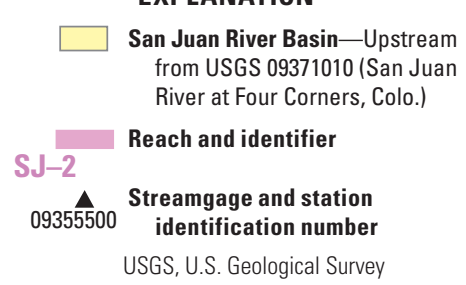

Figure 6. San Juan River Basin, streams, stream reaches, and streamgages upstream from the San Juan River at Four Corners, Colorado (09371010), streamgage in the six-basin study area, New Mexico and parts of bordering States and Mexico. 


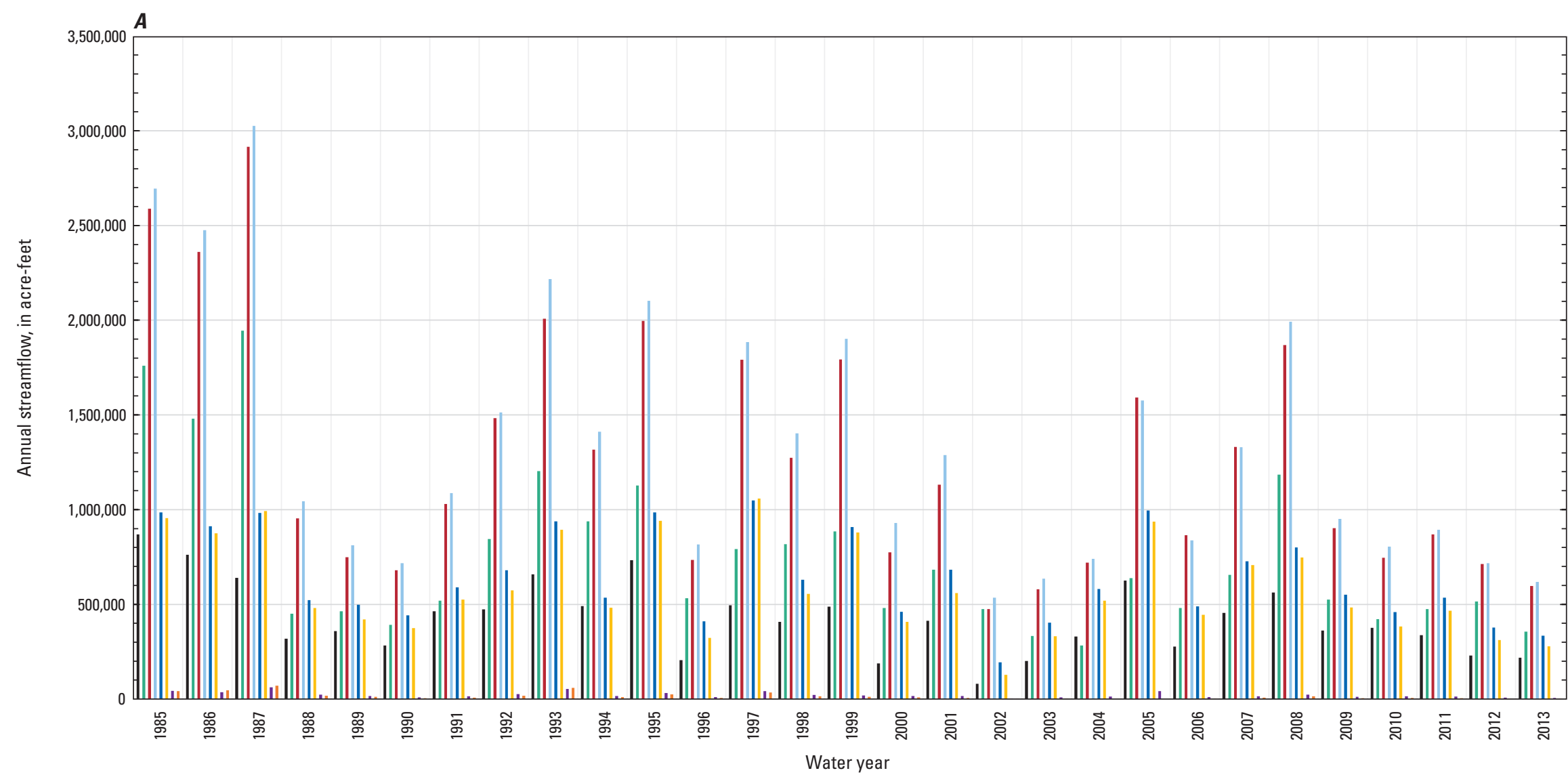

EXPLANATION

Streamgage (station identification number)

- San Juan River near Carracas, Colo. (09346400) - Animas River near Cedar Hill, N. Mex. (09363500)

- San Juan River near Archuleta, N. Mex. (09355500) — Animas River at Farmington, N. Mex. (09364500)

- San Juan River at Shiprock, N. Mex. (09368000) - La Plata River at Colorado-New Mexico State line (09366500)

- San Juan River at Four Corners, Colo. (09371010) La Plata River near Farmington, N. Mex. (09367500)—No data for 2004-05

Figure 7. Annual streamflow, departure from mean annual streamflow, and annual difference in streamflow for streams in the San Juan River Basin in the six-basin study area, New Mexico and parts of bordering States and Mexico, water years 1985-2013.

$A$, San Juan River Basin annual streamflow by streamgage, in downstream order. 


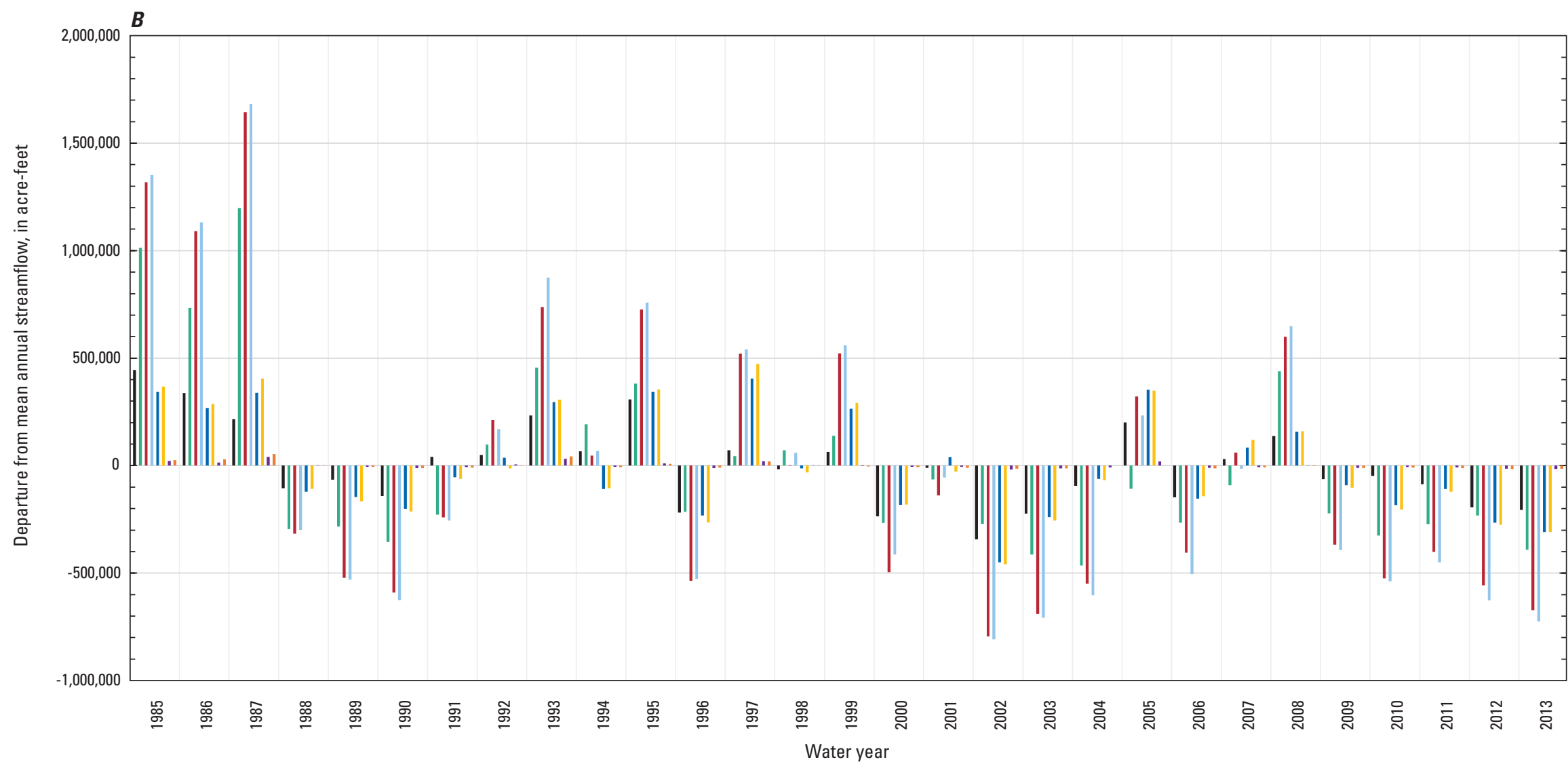

\section{EXPLANATION}

Streamgage (station identification number)

- San Juan River near Carracas, Colo. (09346400)

- Animas River near Cedar Hill, N. Mex. (09363500)

- San Juan River near Archuleta, N. Mex. (09355500)

- Animas River at Farmington, N. Mex. $(09364500)$

- San Juan River at Shiprock, N. Mex. (09368000)

- La Plata River at Colorado-New Mexico State line (09366500)

- San Juan River at Four Corners, Colo. (09371010)

- La Plata River near Farmington, N. Mex. (09367500)—No data for 2004-05

Figure 7. Annual streamflow, departure from mean annual streamflow, and annual difference in streamflow for streams in the San Juan River Basin in the six-basin study area, New Mexico and parts of bordering States and Mexico, water years 1985-2013.-Continued

$B$, Departure of annual streamflow from mean annual streamflow at San Juan River and tributary streamgages. 


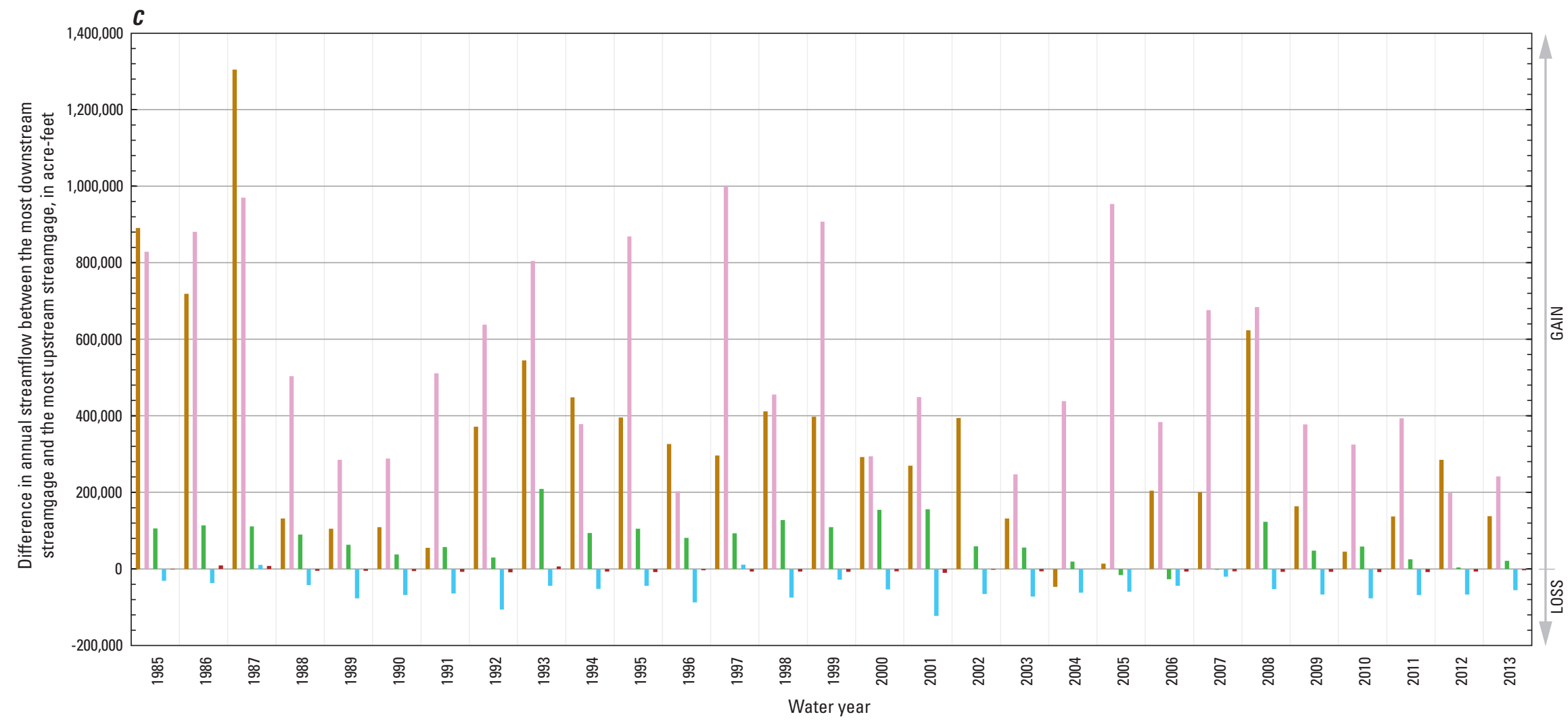

San Juan River (SJ), Animas River (ANI), or La Plata River (PLA)

reach number (annual difference in streamflow)-

Positive average values indicate a gain over that reach

negative average values indic ate a loss over that reach

- SJ-1 (average $+322,683$ acre-feet)

- SJ-2 (average $+523,648$ acre-feet)

n SJ-3 (average $+72,614$ acre-feet)

- ANI-1 (average -55,986 acre-feet)

a PLA-1 (average -4,862 acre-feet)—No data for 2004-05

Figure 7. Annual streamflow, departure from mean annual streamflow, and annual difference in streamflow for streams in the San Juan River Basin in the six-basin study area, 
Table 6. Annual streamflow and annual difference in streamflow by reach for selected San Juan River Basin streamgages in the six-basin study area, New Mexico and parts of bordering States and Mexico, water years 1985-2013.

[Colo., Colorado; acre-ft, acre-feet; N. Mex., New Mexico; --, no data; SJ, San Juan River reach, numbered in downstream order; ANI, Animas River reach, numbered in downstream order; PLA, La Plata River reach, numbered in downstream order]

\begin{tabular}{|c|c|c|c|c|c|c|c|c|}
\hline \multicolumn{9}{|c|}{ Annual streamflow } \\
\hline \multicolumn{5}{|c|}{ San Juan River } & \multicolumn{4}{|c|}{ Tributaries } \\
\hline $\begin{array}{c}\text { Water } \\
\text { year }\end{array}$ & $\begin{array}{l}09346400 \text { San Juan } \\
\text { River near } \\
\text { Carracas, Colo. } \\
\text { (acre-ft) }\end{array}$ & $\begin{array}{c}09355500 \text { San } \\
\text { Juan River near } \\
\text { Archuleta, N. Mex. } \\
\text { (acre-ft) }\end{array}$ & $\begin{array}{c}09368000 \text { San } \\
\text { Juan River at } \\
\text { Shiprock, N. Mex. } \\
\text { (acre-ft) }\end{array}$ & $\begin{array}{l}09371010 \text { San Juan } \\
\text { River at Four } \\
\text { Corners, Colo. } \\
\text { (acre-ft) }\end{array}$ & $\begin{array}{l}09363500 \text { Animas } \\
\text { River near Cedar } \\
\text { Hill, N. Mex. } \\
\text { (acre-ft) }\end{array}$ & $\begin{array}{l}09364500 \text { Animas } \\
\text { River at Farmington, } \\
\text { N. Mex. } \\
\text { (acre-ft) }\end{array}$ & $\begin{array}{l}09366500 \text { La Plata } \\
\text { River at Colorado- } \\
\text { New Mexico } \\
\text { State line } \\
\text { (acre-ft) }\end{array}$ & $\begin{array}{c}09367500 \text { La Plata } \\
\text { River near } \\
\text { Farmington, } \\
\text { N. Mex. } \\
\text { (acre-ft) }\end{array}$ \\
\hline 1985 & 869,300 & $1,760,000$ & $2,589,000$ & $2,695,000$ & 985,600 & 955,000 & 42,840 & 41,460 \\
\hline 1986 & 761,300 & $1,480,000$ & $2,361,000$ & $2,475,000$ & 911,900 & 874,700 & 36,350 & 45,500 \\
\hline 1987 & 640,200 & $1,945,000$ & $2,915,000$ & $3,026,000$ & 981,900 & 992,300 & 62,150 & 69,840 \\
\hline 1988 & 318,800 & 450,800 & 954,100 & $1,044,000$ & 522,000 & 480,100 & 22,510 & 17,280 \\
\hline 1989 & 358,200 & 463,400 & 748,500 & 811,700 & 497,600 & 420,800 & 16,410 & 11,220 \\
\hline 1990 & 282,900 & 391,700 & 679,700 & 717,500 & 442,200 & 374,100 & 9,390 & 3,960 \\
\hline 1991 & 464,100 & 518,900 & $1,030,000$ & $1,087,000$ & 589,300 & 525,300 & 15,210 & 7,330 \\
\hline 1992 & 473,100 & 845,000 & $1,483,000$ & $1,513,000$ & 679,800 & 573,800 & 26,750 & 17,740 \\
\hline 1993 & 657,900 & $1,203,000$ & $2,008,000$ & $2,217,000$ & 938,400 & 893,900 & 52,860 & 59,190 \\
\hline 1994 & 490,100 & 938,600 & $1,317,000$ & $1,411,000$ & 534,700 & 482,700 & 16,520 & 9,680 \\
\hline 1995 & 732,600 & $1,128,000$ & $1,997,000$ & $2,102,000$ & 985,700 & 941,400 & 32,090 & 24,160 \\
\hline 1996 & 205,200 & 531,700 & 734,900 & 815,800 & 410,700 & 322,900 & 10,260 & 6,640 \\
\hline 1997 & 495,300 & 791,300 & $1,791,000$ & $1,884,000$ & $1,048,000$ & $1,059,000$ & 42,180 & 35,350 \\
\hline 1998 & 406,900 & 818,200 & $1,274,000$ & $1,402,000$ & 630,200 & 555,400 & 22,120 & 15,170 \\
\hline 1999 & 488,100 & 885,500 & $1,793,000$ & $1,902,000$ & 907,800 & 879,300 & 19,600 & 12,060 \\
\hline 2000 & 188,400 & 480,400 & 774,600 & 928,800 & 460,600 & 406,900 & 15,910 & 9,360 \\
\hline 2001 & 413,300 & 682,800 & $1,132,000$ & $1,288,000$ & 682,400 & 559,500 & 15,860 & 5,300 \\
\hline 2002 & 81,100 & 475,500 & 475,400 & 534,700 & 193,700 & 128,300 & 3,650 & 1,370 \\
\hline 2003 & 200,600 & 332,600 & 579,900 & 635,600 & 403,400 & 331,100 & 9,110 & 2,820 \\
\hline 2004 & 329,600 & 282,400 & 720,800 & 740,000 & 581,400 & 519,000 & 13,680 & -- \\
\hline 2005 & 624,800 & 638,800 & $1,592,000$ & $1,576,000$ & 995,600 & 936,200 & 41,160 & -- \\
\hline 2006 & 277,200 & 481,200 & 865,000 & 838,100 & 489,500 & 445,200 & 10,380 & 3,460 \\
\hline 2007 & 454,600 & 655,200 & $1,331,000$ & $1,329,000$ & 727,700 & 707,400 & 14,520 & 8,060 \\
\hline 2008 & 561,700 & $1,185,000$ & $1,869,000$ & $1,992,000$ & 800,300 & 747,100 & 22,580 & 14,830 \\
\hline 2009 & 361,000 & 524,800 & 902,600 & 950,400 & 551,300 & 484,200 & 11,430 & 3,880 \\
\hline 2010 & 376,200 & 421,200 & 746,200 & 804,700 & 459,300 & 382,600 & 14,370 & 6,410 \\
\hline 2011 & 337,900 & 475,000 & 868,600 & 893,500 & 534,700 & 466,300 & 12,940 & 4,880 \\
\hline 2012 & 230,400 & 515,200 & 713,300 & 716,800 & 377,900 & 311,100 & 7,440 & 782 \\
\hline 2013 & 218,600 & 356,000 & 597,400 & 618,200 & 333,800 & 278,200 & 6,040 & 2,470 \\
\hline an annual & 424,117 & 746,800 & $1,270,448$ & $1,343,062$ & 643,359 & $\mathbf{5 8 7 , 3 7 2}$ & 21,597 & 16,304 \\
\hline
\end{tabular}

$1,270,448$

643,359

587,372

$\mathbf{2 1 , 5 9 7}$

6,304 
Table 6. Annual streamflow and annual difference in streamflow by reach for selected San Juan River Basin streamgages in the six-basin study area, New Mexico and parts of bordering States and Mexico, water years 1985-2013.-Continued

[Colo., Colorado; acre-ft, acre-feet; N. Mex., New Mexico; --, no data; SJ, San Juan River reach, numbered in downstream order; ANI, Animas River reach, numbered in downstream order; PLA, La Plata River reach, numbered in downstream order]

\begin{tabular}{|c|c|c|c|c|c|}
\hline \multicolumn{6}{|c|}{ Annual difference in streamflow by reach } \\
\hline \multirow[b]{3}{*}{$\begin{array}{l}\text { Water } \\
\text { year }\end{array}$} & \multicolumn{3}{|c|}{ San Juan River } & \multicolumn{2}{|c|}{ Tributaries } \\
\hline & SJ-1 & SJ-2 & SJ-3 & ANI-1 & PLA-1 \\
\hline & $\begin{array}{c}09346400 \text { San Juan River } \\
\text { near Carracas, Colo., } \\
\text { to } 09355500 \text { San Juan River } \\
\text { near Archuleta, N. Mex. } \\
\text { (acre-ft) }\end{array}$ & $\begin{array}{l}09355500 \text { San Juan River } \\
\text { near Archuleta, N. Mex., } \\
\text { to } 09368000 \text { San Juan } \\
\text { River at Shiprock, N. Mex. } \\
\text { (acre-ft) }\end{array}$ & $\begin{array}{l}09368000 \text { San Juan River } \\
\text { at Shiprock, N. Mex., to } \\
09371010 \text { San Juan River } \\
\text { at Four Corners, Colo. } \\
\text { (acre-ft) } \\
\end{array}$ & $\begin{array}{l}09363500 \text { Animas River } \\
\text { near Cedar Hill, N. Mex., to } \\
09364500 \text { Animas River } \\
\text { at Farmington, N. Mex. } \\
\text { (acre-ft) }\end{array}$ & $\begin{array}{c}09366500 \text { La Plata River at } \\
\text { Colorado-New Mexico State } \\
\text { line to } 09367500 \text { La Plata River } \\
\text { near Farmington, N. Mex. } \\
\text { (acre-ft) }\end{array}$ \\
\hline 1985 & 890,700 & 829,000 & 106,000 & $-30,600$ & $-1,380$ \\
\hline 1986 & 718,700 & 881,000 & 114,000 & $-37,200$ & 9,150 \\
\hline 1987 & $1,304,800$ & 970,000 & 111,000 & 10,400 & 7,690 \\
\hline 1988 & 132,000 & 503,300 & 89,900 & $-41,900$ & $-5,230$ \\
\hline 1989 & 105,200 & 285,100 & 63,200 & $-76,800$ & $-5,190$ \\
\hline 1990 & 108,800 & 288,000 & 37,800 & $-68,100$ & $-5,430$ \\
\hline 1991 & 54,800 & 511,100 & 57,000 & $-64,000$ & $-7,880$ \\
\hline 1992 & 371,900 & 638,000 & 30,000 & $-106,000$ & $-9,010$ \\
\hline 1993 & 545,100 & 805,000 & 209,000 & $-44,500$ & 6,330 \\
\hline 1994 & 448,500 & 378,400 & 94,000 & $-52,000$ & $-6,840$ \\
\hline 1995 & 395,400 & 869,000 & 105,000 & $-44,300$ & $-7,930$ \\
\hline 1996 & 326,500 & 203,200 & 80,900 & $-87,800$ & $-3,620$ \\
\hline 1997 & 296,000 & 999,700 & 93,000 & 11,000 & $-6,830$ \\
\hline 1998 & 411,300 & 455,800 & 128,000 & $-74,800$ & $-6,950$ \\
\hline 1999 & 397,400 & 907,500 & 109,000 & $-28,500$ & $-7,540$ \\
\hline 2000 & 292,000 & 294,200 & 154,200 & $-53,700$ & $-6,550$ \\
\hline 2001 & 269,500 & 449,200 & 156,000 & $-122,900$ & $-10,560$ \\
\hline 2002 & 394,400 & -100 & 59,300 & $-65,400$ & $-2,280$ \\
\hline 2003 & 132,000 & 247,300 & 55,700 & $-72,300$ & $-6,290$ \\
\hline 2004 & $-47,200$ & 438,400 & 19,200 & $-62,400$ & -- \\
\hline 2005 & 14,000 & 953,200 & $-16,000$ & $-59,400$ & -- \\
\hline 2006 & 204,000 & 383,800 & $-26,900$ & $-44,300$ & $-6,920$ \\
\hline 2007 & 200,600 & 675,800 & $-2,000$ & $-20,300$ & $-6,460$ \\
\hline 2008 & 623,300 & 684,000 & 123,000 & $-53,200$ & $-7,750$ \\
\hline 2009 & 163,800 & 377,800 & 47,800 & $-67,100$ & $-7,550$ \\
\hline 2010 & 45,000 & 325,000 & 58,500 & $-76,700$ & $-7,960$ \\
\hline 2011 & 137,100 & 393,600 & 24,900 & $-68,400$ & $-8,060$ \\
\hline 2012 & 284,800 & 198,100 & 3,500 & $-66,800$ & $-6,658$ \\
\hline 2013 & 137,400 & 241,400 & 20,800 & $-55,600$ & $-3,570$ \\
\hline $\begin{array}{r}\text { Mean annual } \\
\text { streamflow } \\
\end{array}$ & 322,683 & 523,648 & 72,614 & $-55,986$ & $-4,862$ \\
\hline
\end{tabular}


Departure from mean annual streamflow on the Animas River was positive from 1985 to 1987 but was negative from 1988 to 1991, except for one positive year at the Animas River near Cedar Hill, N. Mex. (09363500), streamgage in 1991 (fig. 7B). From 1993 to 2001, departures were variable. In 2002, the most negative departure for the study period occurred, but the magnitude of the departures decreased from 2002 to 2005. From 2006 to 2013, departures generally remained negative, with positive departures in 2007 and 2008 (fig. 7B).

\section{La Plata River}

The La Plata River, located west of the Animas River, originates in Colorado and flows south to join the San Juan River near Farmington (fig. 6). The streamgages selected for this study were the La Plata River at Colorado-New Mexico State line (09366500) streamgage and the La Plata River near Farmington, N. Mex. (09367500), streamgage. The La Plata River near Farmington, N. Mex. (09367500), streamgage record is missing data for 2004 and for 9 months of 2005 (fig. 7A; table 6). The La Plata River is a smaller tributary in volume of flow than the Animas River. Annual flows at the La Plata River near Farmington, N. Mex. (09367500), streamgage, representing flow into the San Juan River, generally were less than the annual inflow to the State at the La Plata River at Colorado-New Mexico State line (09366500) streamgage. Annual flows at the La Plata River at ColoradoNew Mexico State line (09366500) streamgage ranged from 3,650 acre-ft in 2002 to 62,150 acre-ft in 1987, with a mean annual streamflow of 21,597 acre-ft. Annual flows at the La Plata River near Farmington, N. Mex. (09367500), streamgage, disregarding the years of missing data, ranged from 782 acre-ft in 2012 to 69,840 acre-ft in 1987, with a mean annual streamflow of 16,304 acre-ft (fig. $7 A$; table 6).

Departures from mean annual streamflow in the La Plata River were positive from 1985 to 1987 but decreased to near average flows in 1998 (fig. 7B). After 1987, departures from mean annual streamflow were close to zero, except for 1993 and 1997 (fig. 7B).

\section{San Juan River Basin Gains and Losses}

\section{San Juan River}

Gains and losses were estimated for three San Juan River reaches (fig. 6), with reach SJ-1 including Navajo Reservoir. Gains and losses for reach SJ-1 ranged from a gain of 1,304,800 acre-ft in 1987 to the only loss, 47,200 acre-ft, in 2004 and had a mean annual gain of 322,683 acre-ft (fig. 7C; table 6). Gains and losses for reach SJ-2 ranged from a gain of 999,700 acre-ft in 1997 to the only loss, 100 acre-ft, in 2002 and had a mean annual gain of 523,648 acre-ft. Gains and losses for reach SJ-3 ranged from a gain of 209,000 acre-ft in
1993 to a loss of 26,900 acre-ft in 2006 and had a mean annual gain of 72,614 acre-ft. Of the three San Juan River reaches, the second, reach SJ-2, consistently had the greatest gains, except for 1985, 1987, 1994, 1996, 2002, and 2012, when the first, reach $\mathrm{SJ}-1$, had the greatest gains.

Annual gains for reaches SJ-1 (average gain of 322,683 acre-ft) and SJ-2 (average gain of 523,648 acre-ft) from 1985 to 1987 were above average but after 1987 dropped below average until 1992 (fig. 7C; table 6). From 1992 to 1996, reach SJ-1 had above average gains, fell below average in 1997, and then rose to above average from 1998 to 1999. From 2000 to 2013, reach SJ-1 recorded only two above average gains, in 2002 and 2008. Reach SJ-2 had above average gains in 1992 and 1993. From 1994 to 1999, above average gains were recorded in 1995, 1997, and 1999. From 2000 to 2013, reach SJ-2 had above average gains in 2005, 2007, and 2008 (fig. 7C; table 6).

Reach SJ-3 (average gain of 72,614 acre-ft) had above average gains from 1985 to 1988, but gains fell below average from 1989 to 1992. From 1993 to 2001, reach SJ-3 recorded above average gains, but from 2002 to 2013, this reach had three losses (2005-07) and one above average gain (2008) (fig. $7 C$; table 6).

\section{Animas River}

Over the study period, the Animas River reach, ANI-1 (fig. 6), generally was a losing reach except for 1987 and 1997, with a mean annual loss of 55,986 acre-ft (fig. 7C; table 6). From 1985 to 2000 , above average losses were less frequent, and losses were lower than those from 2000 to 2013. The 2001 annual loss of 122,900 acre-ft was the largest loss for the study period, and above average losses occurred for the remaining years except for 2006-08 and 2013, where losses were just below the average losses (fig. $7 C$; table 6).

\section{La Plata River}

Over the study period, the La Plata River reach, PLA-1 (fig. 6), generally was a losing reach except for 1986, 1987, and 1993 (fig. 7C; table 6). Reach PLA-1 had its greatest annual gain, 9,150 acre-ft, in 1986. Annual losses for reach PLA-1 are fairly consistent over the study period, and most are above the mean annual loss of 4,862 acre-ft. Reach PLA-1 had below average losses in 1985, 1996, 2002, and 2013. The greatest annual loss, 10,560 acre-ft, occurred in 2001 (fig. $7 C$; table 6).

\section{Canadian River Basin Streamflow}

\section{Canadian River}

The Canadian River Basin is in the northeastern corner of New Mexico (fig. 8). The Canadian River originates in southern 
Colorado, flows through the northeastern corner of New Mexico, and exits the State along its eastern border. There are Eagle Nest Lake on the Cimarron River and Conchas Lake and Ute Reservoir on the Canadian River. Three Canadian River streamgages and two Cimarron River streamgages were selected for this study (fig. 8). Monthly values for these streamgages are presented in appendix 7.

Annual flows at the Canadian River near Sanchez, N. Mex. (07221500), streamgage were higher than at other streamgages, with a mean annual streamflow of 92,103 acre-ft for the study period, and ranged from a high of 335,800 acre-ft in 1987 to a low of 2,580 acre-ft in 2012 (fig. $9 A$; table 7). The most upstream streamgage, the Canadian River near Taylor Springs, N. Mex. (07211500), had a mean annual streamflow of 42,550 acre-ft and ranged from a high of 182,900 acre-ft in 1987 to a low of 1,570 acre-ft in 2012. The most downstream streamgage, Canadian River at Logan, N. Mex. (07227000), had the lowest mean annual streamflow at 22,281 acre-ft and ranged from a high of 104,800 acre-ft in 1999 to a low of 1,670 acre-ft in 1986. The low mean annual streamflow at the Canadian River at Logan, N. Mex. (07227000), streamgage may be, in part, attributable to the reservoirs storing water upstream from this streamgage (fig. $9 A$; table 7). Prior to 1999, departures from mean annual streamflow at the Canadian River streamgages were variable, but after 1999, departures generally were negative (fig. 9B).

The lowest annual flows occurred in 2003, 2011, and 2012. The Canadian River at Logan, N. Mex. (07227000), streamgage had low flows from 2001 to 2013 , with a small peak in 2006 (fig. 9A; table 7). Inflow from the Canadian River in Colorado is unknown (ungaged) but for the purposes of this report is assumed to be zero. The annual outflow from New Mexico at the Canadian River at Logan, N. Mex. (07227000), streamgage ranged from a low of 1,670 acre-ft in 1986 to a high of 104,800 acre-ft in 1999 (table 2).

\section{Cimarron River}

The Cimarron River joins the Canadian River upstream from the Canadian River near Taylor Springs, N. Mex. (07211500), streamgage. Eagle Nest Lake (fig. 8) is upstream from both streamgages selected for this study, the Cimarron River below Eagle Nest Dam, N. Mex. (07206000), streamgage and the Cimarron River near Cimarron, N. Mex. (07207000), streamgage. Over the study period, Cimarron River mean annual streamflows were 14,010 acre- $\mathrm{ft}$ at the Cimarron River below Eagle Nest Dam, N. Mex. (07206000), streamgage and were 19,091 acre-ft at the Cimarron River near Cimarron, N. Mex. (07207000), streamgage (table 7). Annual flows at the Cimarron River below Eagle Nest Dam, N. Mex. (07206000), streamgage ranged from 6,200 acre-ft in 2004 to 40,890 acre-ft in 1994 and at the Cimarron River near Cimarron, N. Mex. (07207000), streamgage ranged from 9,050 acre-ft in 2002 to 58,410 in 1994 (fig. 9A; table 7). Departures from mean annual streamflow for the Cimarron
River were variable through 1999 but generally were negative through 2013 (fig. 9B).

\section{Canadian River Basin Gains and Losses}

\section{Canadian River}

Over the study period, reach CAN-1 (fig. 8) was a gaining reach for all 29 years, with the greatest annual gain, 168,400 acre-ft, in 1999, the smallest annual gain, 490 acre-ft, in 2003, and a mean annual gain of 49,553 acre-ft (fig. $9 C$; table 7). Gains generally were above average from 1985 to 1999 but fell below average in 2000 and generally remained below average through 2013. For 1985-2013, reach CAN-2 (fig. 8) was a losing reach for all years except 2003 (fig. 9C; table 7). Reach CAN-2 gains and losses ranged from a gain of 110 acre-ft in 2003 to a loss of 235,900 acre-ft in 1987 and a mean annual loss over the study period of 69,822 acre-ft. Losses generally were below the mean before 1999, but thereafter losses tended to be above the mean.

No inflow to the State is reported for the Canadian River because the first streamgage of the study is in New Mexico (fig. 8). Gain/loss was not computed for the entirety of the stream, but the Canadian River contributed a mean annual outflow of 22,281 acre-ft and a total outflow of 646,160 from 1985 to 2013 (table 2).

\section{Cimarron River}

Over the study period, reach CIM-1 (fig. 8) generally was gaining except for 1996, 2002, 2011, and 2013 (fig. 9C; table 7). The mean annual gain for reach CIM-1 was 5,082 acre-ft. There were 13 above average annual gains over the 29-year study period. The annual gains and losses ranged from a gain of 17,520 acre-ft in 1994 to a loss of 2,330 acre-ft in 2002 .

\section{Gila River Basin Streamflow}

The Gila River originates in southwestern New Mexico, flows across the western State border, and joins the San Francisco River near Clifton, Ariz. (fig. 10). No tributaries to the Gila River were included in this study, and there are no major reservoirs on this river. The three streamgages selected for this study were the Gila River near Gila, N. Mex. (09430500), streamgage; the Gila River below Blue Creek, near Virden, N. Mex. (09432000), streamgage; and the Gila River near Clifton, Ariz. (09442000), streamgage (fig. 10). The Gila River near Clifton, Ariz. (09442000), streamgage record is missing data from 1990 to 1995 (table 8). Monthly streamflow values for these streamgages are presented in appendix 8. 


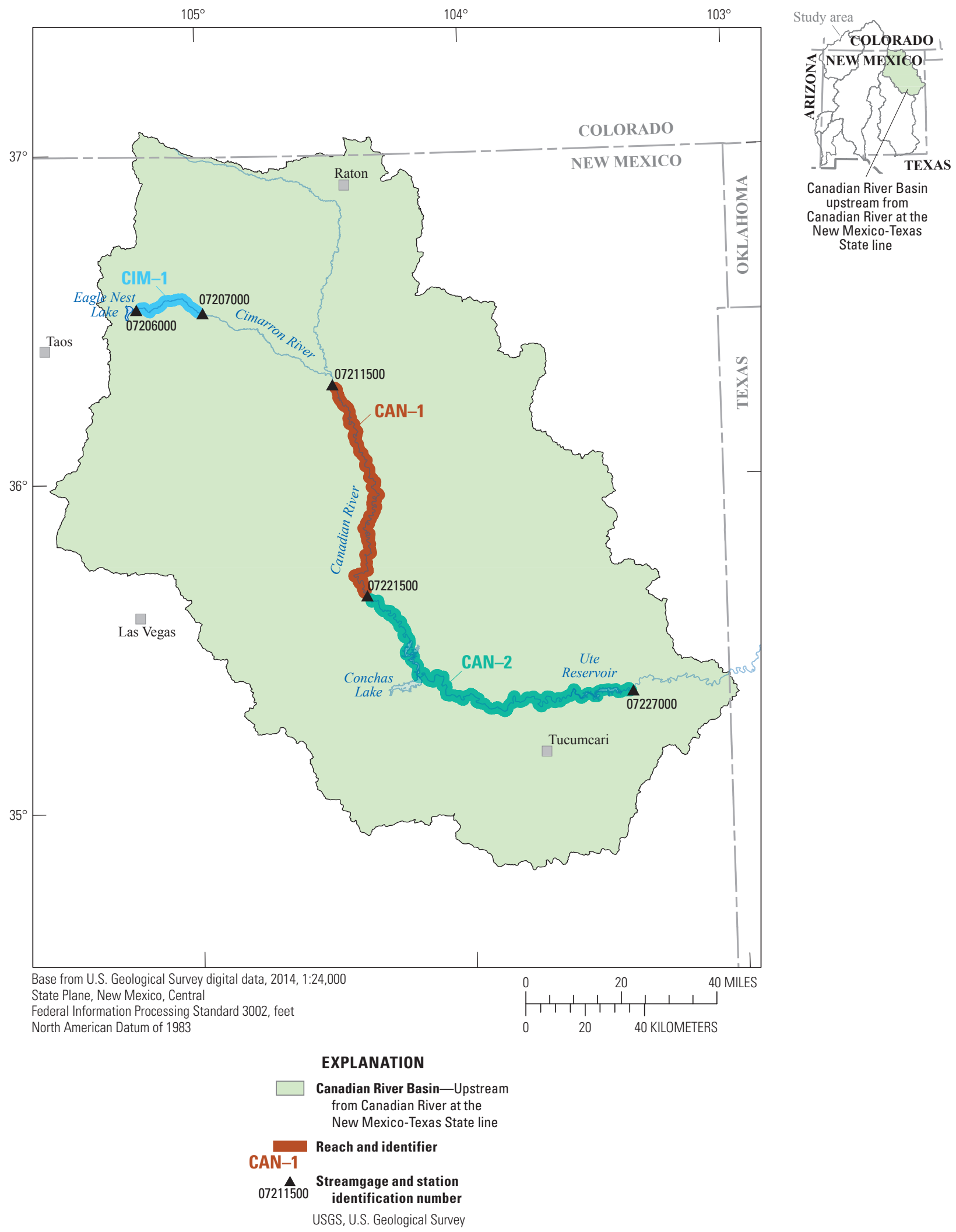

Figure 8. Canadian River Basin, streams, stream reaches, and streamgages upstream from the Canadian River at the New MexicoTexas State line in the six-basin study area, New Mexico and parts of bordering States and Mexico. 


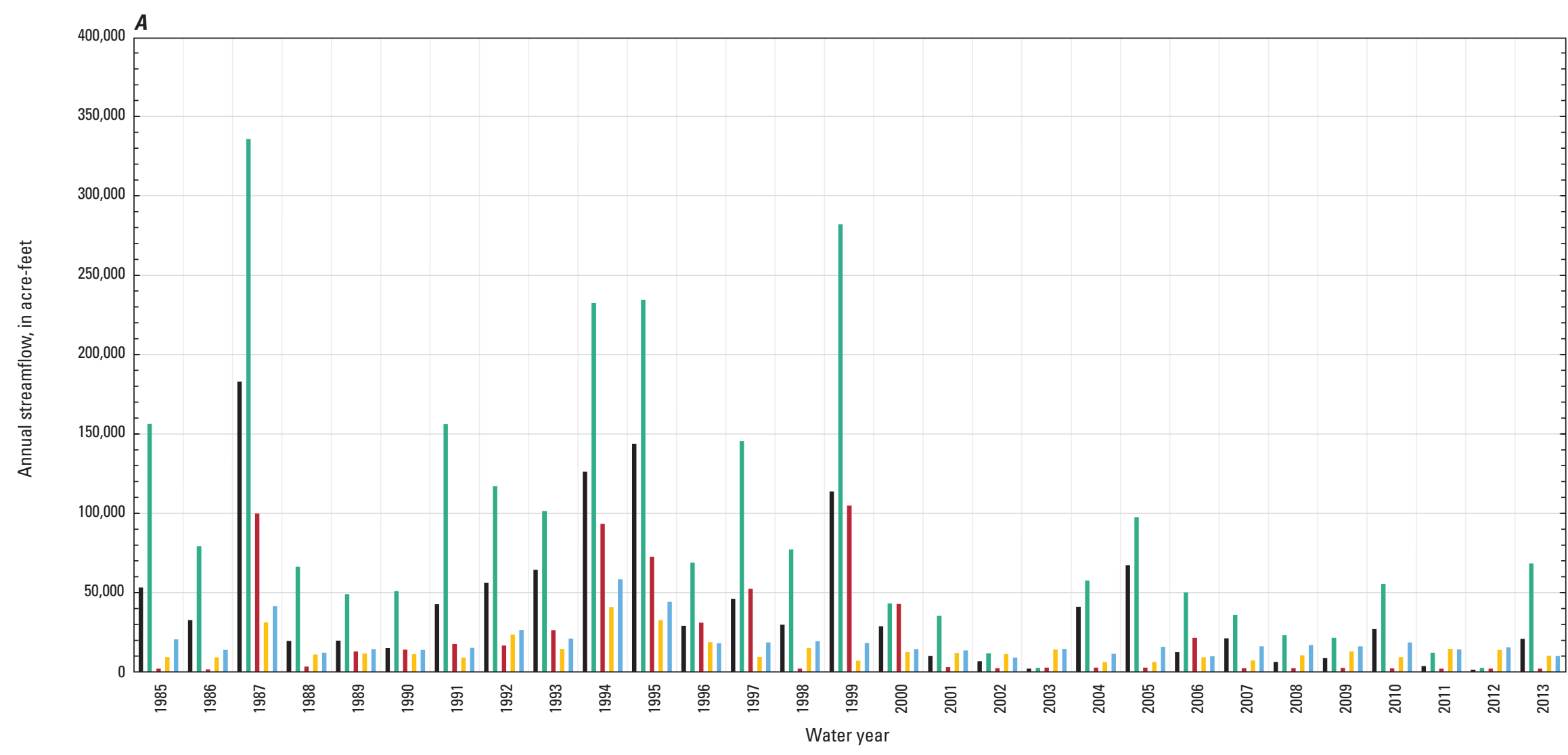

EXPLANATION

\section{Streamgage (station identification number)}

- Canadian River near Taylor Springs, N. Mex. (07211500) ㅍ Cimarron River below Eagle Nest Dam, N. Mex. (07206000)

- Canadian River near Sanchez, N. Mex. (07221500) - Cimarron River near Cimarron, N. Mex. (07207000)

- Canadian River at Logan, N. Mex. (07227000)

Figure 9. Annual streamflow, departure from mean annual streamflow, and annual difference in streamflow for streams in the Canadian River Basin in the six-basin study area, New Mexico and parts of bordering States and Mexico, water years 1985-2013.

$A$, Canadian River Basin annual streamflow by streamgage, in downstream order. 


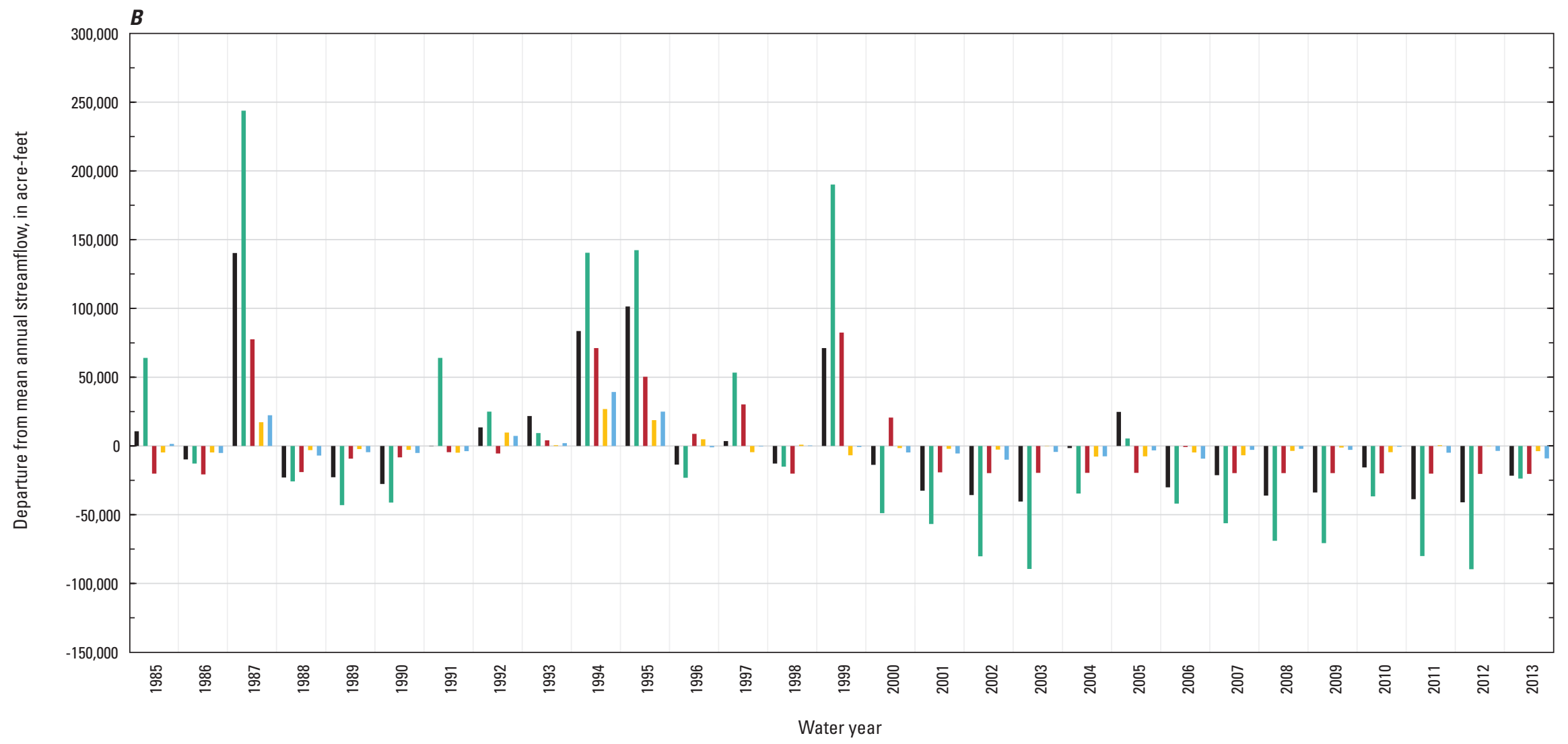

EXPLANATION

\section{Streamgage (station identification number)}

- Canadian River near Taylor Springs, N. Mex. (07211500) - Cimarron River below Eagle Nest Dam, N. Mex. (07206000)

- Canadian River near Sanchez, N. Mex. (07221500) - Cimarron River near Cimarron, N. Mex. (07207000)

- Canadian River at Logan, N. Mex. $(07227000)$

Figure 9. Annual streamflow, departure from mean annual streamflow, and annual difference in streamflow for streams in the Canadian River Basin in the six-basin study area, New Mexico and parts of bordering States and Mexico, water years 1985-2013.-Continued

$B$, Departure of annual streamflow from mean annual streamflow at Canadian River and tributary streamgages. 


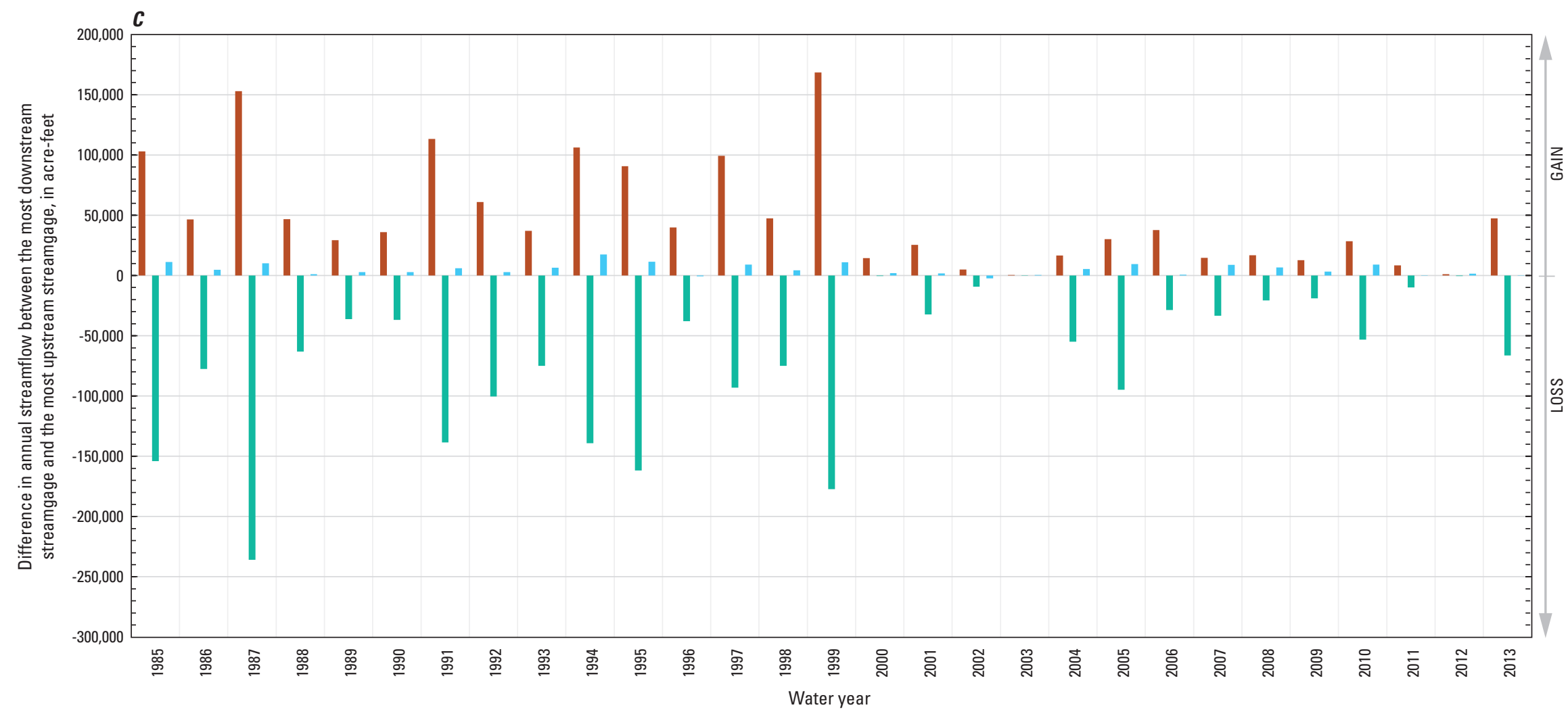

\section{EXPLANATION}

Canadian River (CAN) or Cimarron River (CIM)

reach number (annual difference in streamflow)-

Positive average values indicate a gain over that reach;

negative average values indicate a loss over that reach

- CAN-1 (average +49,553 acre-feet)

- CAN-2 (average -69,822 acre-feet)

- CIM-1 (average +5,082 acre-feet)

Figure 9. Annual streamflow, departure from mean annual streamflow, and annual difference in streamflow for streams in the Canadian River Basin in the six-basin study area, New Mexico and parts of bordering States and Mexico, water years 1985-2013.-Continued

$C$, Canadian River Basin annual difference in streamflow by reach. 
Table 7. Annual streamflow and annual difference in streamflow by reach for selected Canadian River Basin streamgages in the six-basin study area, New Mexico and parts of bordering States and Mexico, water years 1985-2013.

[N. Mex., New Mexico; acre-ft, acre-feet; CAN, Canadian River reach, numbered in downstream order; CIM, Cimarron River reach, numbered in downstream order]

\begin{tabular}{|c|c|c|c|c|c|c|c|c|}
\hline \multicolumn{6}{|c|}{ Annual streamflow } & \multicolumn{3}{|c|}{ Annual difference in streamflow by reach } \\
\hline \multirow{2}{*}{\multicolumn{4}{|c|}{ Canadian River }} & \multirow{2}{*}{\multicolumn{2}{|c|}{ Tributary }} & \multicolumn{2}{|c|}{ Canadian River } & \multirow{3}{*}{$\begin{array}{c}\text { Tributary } \\
\text { CIM-1 } \\
07206000 \text { Cimarron Rive } \\
\text { below Eagle Nest Dam, } \\
\text { N. Mex., to 07207000 } \\
\text { Cimarron River near } \\
\text { Cimarron, N. Mex. } \\
\text { (acre-ft) }\end{array}$} \\
\hline & & & & & & \multirow[b]{2}{*}{$\begin{array}{c}\text { CAN-1 } \\
07211500 \text { Canadian River } \\
\text { near Taylor Springs, } \\
\text { N. Mex., to 07221500 } \\
\text { Canadian River near } \\
\text { Sanchez, N. Mex. } \\
\text { (acre-ft) }\end{array}$} & \multirow[b]{2}{*}{$\begin{array}{c}\text { CAN-2 } \\
\text { 07221500 Canadian } \\
\text { River near Sanchez, } \\
\text { N. Mex., to } 07227000 \\
\text { Canadian River at } \\
\text { Logan, N. Mex. } \\
\text { (acre-ft) }\end{array}$} & \\
\hline $\begin{array}{c}\text { Water } \\
\text { year }\end{array}$ & $\begin{array}{c}07211500 \\
\text { Canadian River } \\
\text { near Taylor } \\
\text { Springs, } \\
\text { N. Mex. } \\
\text { (acre-ft) }\end{array}$ & $\begin{array}{c}07221500 \\
\text { Canadian River } \\
\text { near Sanchez, } \\
\text { N. Mex. } \\
\text { (acre-ft) }\end{array}$ & $\begin{array}{c}07227000 \\
\text { Canadian River } \\
\text { at Logan, } \\
\text { N. Mex. } \\
\text { (acre-ft) }\end{array}$ & $\begin{array}{c}07206000 \\
\text { Cimarron River } \\
\text { below Eagle } \\
\text { Nest Dam, } \\
\text { N. Mex. } \\
\text { (acre-ft) }\end{array}$ & $\begin{array}{c}07207000 \\
\text { Cimarron } \\
\text { River near } \\
\text { Cimarron, } \\
\text { N. Mex. } \\
\text { (acre-ft) }\end{array}$ & & & \\
\hline 1985 & 53,200 & 156,200 & 2,090 & 9,370 & 20,560 & 103,000 & $-154,110$ & 11,190 \\
\hline 1986 & 32,740 & 79,310 & 1,670 & 9,270 & 13,990 & 46,570 & $-77,640$ & 4,720 \\
\hline 1987 & 182,900 & 335,800 & 99,900 & 31,250 & 41,460 & 152,900 & $-235,900$ & 10,210 \\
\hline 1988 & 19,670 & 66,420 & 3,370 & 11,020 & 12,120 & 46,750 & $-63,050$ & 1,100 \\
\hline 1989 & 19,800 & 49,110 & 13,000 & 11,650 & 14,510 & 29,310 & $-36,110$ & 2,860 \\
\hline 1990 & 15,020 & 50,990 & 14,080 & 11,160 & 14,020 & 35,970 & $-36,910$ & 2,860 \\
\hline 1991 & 42,740 & 156,100 & 17,670 & 9,150 & 15,250 & 113,360 & $-138,430$ & 6,100 \\
\hline 1992 & 56,130 & 117,100 & 16,770 & 23,670 & 26,490 & 60,970 & $-100,330$ & 2,820 \\
\hline 1993 & 64,390 & 101,400 & 26,350 & 14,610 & 21,080 & 37,010 & $-75,050$ & 6,470 \\
\hline 1994 & 126,200 & 232,500 & 93,360 & 40,890 & 58,410 & 106,300 & $-139,140$ & 17,520 \\
\hline 1995 & 143,900 & 234,500 & 72,640 & 32,740 & 44,140 & 90,600 & $-161,860$ & 11,400 \\
\hline 1996 & 29,070 & 68,980 & 31,150 & 18,850 & 18,180 & 39,910 & $-37,830$ & -670 \\
\hline 1997 & 46,150 & 145,500 & 52,460 & 9,530 & 18,670 & 99,350 & $-93,040$ & 9,140 \\
\hline 1998 & 29,810 & 77,130 & 2,210 & 15,010 & 19,400 & 47,320 & $-74,920$ & 4,390 \\
\hline 1999 & 113,700 & 282,100 & 104,800 & 7,170 & 18,250 & 168,400 & $-177,300$ & 11,080 \\
\hline 2000 & 28,830 & 43,290 & 42,860 & 12,520 & 14,410 & 14,460 & -430 & 1,890 \\
\hline 2001 & 10,070 & 35,420 & 3,130 & 12,000 & 13,630 & 25,350 & $-32,290$ & 1,630 \\
\hline 2002 & 6,870 & 11,860 & 2,510 & 11,380 & 9,050 & 4,990 & $-9,350$ & $-2,330$ \\
\hline 2003 & 2,210 & 2,700 & 2,810 & 14,230 & 14,670 & 490 & 110 & 440 \\
\hline 2004 & 41,100 & 57,600 & 2,710 & 6,200 & 11,600 & 16,500 & $-54,890$ & 5,400 \\
\hline 2005 & 67,300 & 97,540 & 2,790 & 6,410 & 15,940 & 30,240 & $-94,750$ & 9,530 \\
\hline 2006 & 12,440 & 50,240 & 21,580 & 9,290 & 9,880 & 37,800 & $-28,660$ & 590 \\
\hline 2007 & 21,260 & 35,870 & 2,500 & 7,270 & 16,190 & 14,610 & $-33,370$ & 8,920 \\
\hline 2008 & 6,420 & 23,200 & 2,540 & 10,490 & 17,090 & 16,780 & $-20,660$ & 6,600 \\
\hline 2009 & 8,750 & 21,520 & 2,600 & 12,960 & 16,180 & 12,770 & $-18,920$ & 3,220 \\
\hline 2010 & 27,040 & 55,530 & 2,360 & 9,480 & 18,570 & 28,490 & $-53,170$ & 9,090 \\
\hline 2011 & 3,760 & 12,100 & 2,120 & 14,550 & 14,260 & 8,340 & $-9,980$ & -290 \\
\hline 2012 & 1,570 & 2,580 & 2,060 & 13,920 & 15,510 & 1,010 & -520 & 1,590 \\
\hline 2013 & 20,920 & 68,410 & 2,070 & 10,240 & 10,140 & 47,490 & $-66,340$ & -100 \\
\hline $\begin{array}{r}\text { Mean annual } \\
\text { streamflow }\end{array}$ & 42,550 & 92,103 & 22,281 & 14,010 & 19,091 & 49,553 & $-69,822$ & 5,082 \\
\hline
\end{tabular}



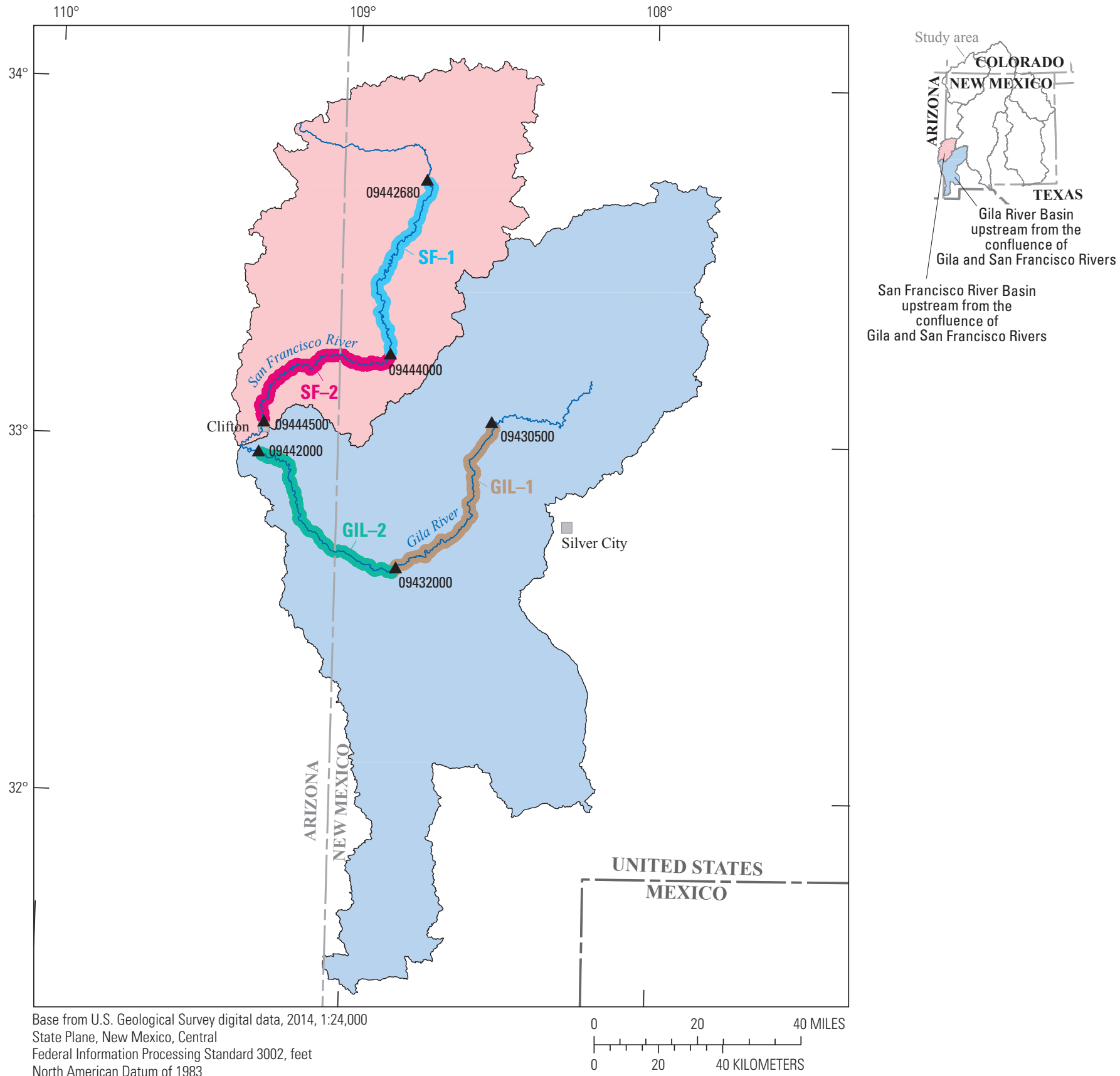

Gila and San Francisco Rivers

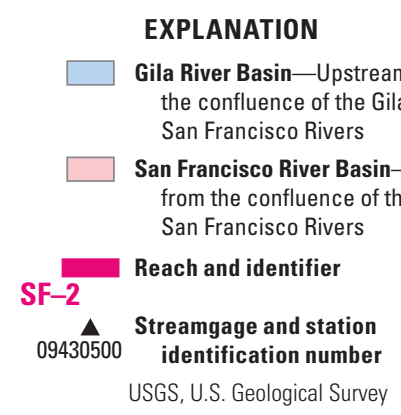

Figure 10. Gila and San Francisco River Basins, streams, stream reaches, and streamgages upstream from the confluence of the Gila and San Francisco Rivers in the six-basin study area, New Mexico and parts of bordering States and Mexico. 
Table 8. Annual streamflow and annual difference in streamflow by reach for selected Gila River Basin streamgages in the six-basin study area, New Mexico and parts of bordering States and Mexico, water years 1985-2013.

[N. Mex., New Mexico; acre-ft, acre-feet; Ariz., Arizona; GIL, Gila River reach, numbered in downstream order; --, no data]

\begin{tabular}{|c|c|c|c|c|c|}
\hline \multicolumn{4}{|c|}{ Annual streamflow } & \multicolumn{2}{|c|}{ Annual difference in streamflow by reach } \\
\hline & & & & GIL-1 & GIL-2 \\
\hline $\begin{array}{c}\text { Water } \\
\text { year }\end{array}$ & $\begin{array}{l}09430500 \text { Gila River } \\
\text { near Gila, N. Mex. } \\
\text { (acre-ft) }\end{array}$ & $\begin{array}{l}\text { below Blue Creek, } \\
\text { near Virden, N. Mex. } \\
\text { (acre-ft) }\end{array}$ & $\begin{array}{l}09442000 \text { Gila River } \\
\text { near Clifton, Ariz. } \\
\text { (acre-ft) }\end{array}$ & $\begin{array}{c}09430500 \text { Gila River near Gila, N. Mex., } \\
\text { to } 09432000 \text { Gila River below } \\
\text { Blue Creek, near Virden, N. Mex. } \\
\text { (acre-ft) }\end{array}$ & $\begin{array}{c}09432000 \text { Gila River below Blue Creek, } \\
\text { near Virden, N. Mex., to } 09442000 \\
\text { Gila River near Clifton, Ariz. } \\
\text { (acre-ft) }\end{array}$ \\
\hline 1985 & 305,900 & 405,100 & 374,000 & 99,200 & $-31,100$ \\
\hline 1986 & 153,300 & 237,500 & 193,800 & 84,200 & $-43,700$ \\
\hline 1987 & 127,900 & 156,100 & 142,300 & 28,200 & $-13,800$ \\
\hline 1988 & 191,900 & 232,800 & 200,300 & 40,900 & $-32,500$ \\
\hline 1989 & 64,800 & 80,500 & 78,180 & 15,700 & $-2,320$ \\
\hline 1990 & 58,300 & 54,830 & -- & $-3,470$ & -- \\
\hline 1991 & 223,400 & 295,600 & -- & 72,200 & -- \\
\hline 1992 & 240,600 & 377,700 & -- & 137,100 & -- \\
\hline 1993 & 310,100 & 539,900 & -- & 229,800 & -- \\
\hline 1994 & 54,820 & 72,520 & -- & 17,700 & -- \\
\hline 1995 & 227,300 & 408,300 & -- & 181,000 & -- \\
\hline 1996 & 63,280 & 94,260 & 93,800 & 30,980 & -460 \\
\hline 1997 & 152,800 & 213,400 & 193,000 & 60,600 & $-20,400$ \\
\hline 1998 & 147,800 & 215,000 & 201,800 & 67,200 & $-13,200$ \\
\hline 1999 & 74,660 & 93,640 & 95,340 & 18,980 & 1,700 \\
\hline 2000 & 36,740 & 45,540 & 42,990 & 8,800 & $-2,550$ \\
\hline 2001 & 113,100 & 164,100 & 138,200 & 51,000 & $-25,900$ \\
\hline 2002 & 42,920 & 56,690 & 45,210 & 13,770 & $-11,480$ \\
\hline 2003 & 48,160 & 56,870 & 47,610 & 8,710 & $-9,260$ \\
\hline 2004 & 77,730 & 115,900 & 98,030 & 38,170 & $-17,870$ \\
\hline 2005 & 250,600 & 367,600 & 301,900 & 117,000 & $-65,700$ \\
\hline 2006 & 135,000 & 202,400 & 197,100 & 67,400 & $-5,300$ \\
\hline 2007 & 109,400 & 142,600 & 130,700 & 33,200 & $-11,900$ \\
\hline 2008 & 141,700 & 177,100 & 152,700 & 35,400 & $-24,400$ \\
\hline 2009 & 56,620 & 60,720 & 60,490 & 4,100 & -230 \\
\hline 2010 & 155,800 & 237,600 & 210,500 & 81,800 & $-27,100$ \\
\hline 2011 & 47,100 & 48,740 & 39,580 & 1,640 & $-9,160$ \\
\hline 2012 & 59,760 & 65,810 & 55,320 & 6,050 & $-10,490$ \\
\hline 2013 & 204,600 & 155,900 & 134,100 & $-48,700$ & $-21,800$ \\
\hline $\begin{array}{r}\text { Mean annual } \\
\text { streamflow }\end{array}$ & 133,658 & 185,335 & 140,302 & 51,677 & $-17,344$ \\
\hline
\end{tabular}


Over the study period, mean annual streamflow was 133,658 acre-ft at the Gila River near Gila, N. Mex. (09430500), streamgage; 185,335 acre-ft at the Gila River below Blue Creek, near Virden, N. Mex. (09432000), streamgage; and 140,302 acre-ft at the Gila River near Clifton, Ariz. (09442000), streamgage (table 8). Over the study period, annual flows at the Gila River near Gila, N. Mex. (09430500), streamgage ranged from 36,740 acre-ft in 2000 to 310,100 acre-ft in 1993, at the Gila River below Blue Creek, near Virden, N. Mex. (09432000), streamgage ranged from 45,540 in 2000 to 539,900 acre-ft in 1993, and at the Gila River near Clifton, Ariz. (09442000), streamgage ranged from 39,580 acre-ft in 2011 to 374,000 acre-ft in 1985 (fig. 11A; table 8). Annual flows at the Gila River below Blue Creek, near Virden, N. Mex. (09432000), streamgage generally were higher than at the other two streamgages, except for 1990, 1999, and 2013 (fig. 11A; table 8). Departures from mean annual streamflow on the Gila River were variable from 1985 to 1998 and generally were negative thereafter, except for 2005-06 and 2010 (fig. 11B).

\section{Gila River Basin Gains and Losses}

Over the study period, reach GIL-1 (fig. 10) was a gaining reach for all years except 1990 and 2013 (fig. 11C; table 8). Gains and losses for reach GIL-1 ranged from a gain of 229,800 acre-ft in 1993 to a loss of 48,700 acre-ft in 2013, with a mean annual gain of 51,677 acre-ft over the study period. In general, gains in reach GIL-1 decreased over the study period. Reach GIL-2 (fig. 10) was a losing reach for all years with data except 1999. Annual gains and losses ranged from a gain of 1,700 acre-ft in 1999 to a loss of 65,700 acre-ft in 2005, with a mean annual loss of 17,344 acre-ft over the study period. Losses were relatively low (fig. $11 C$; table 8) as compared to other streams included in this study.

The Gila River does not have inflow to the State since it originates in New Mexico (fig. 10). A gain/loss computation was not done for the entirety of the stream, but the Gila River contributed a mean annual outflow of 140,302 acre-ft and a total outflow of 3,226,950 acre-ft from 1985 to 2013 (table 2).

\section{San Francisco River Basin Streamflow}

The San Francisco River originates in New Mexico, flows into Arizona, and joins the Gila River near Clifton, Ariz. (fig. 10). No tributaries were included for this basin, and there are no major reservoirs on the reaches of the San Francisco River included in this study. Three San Francisco River streamgages were selected for this study: the San Francisco River near Reserve, N. Mex. (09442680), streamgage; the San Francisco River near Glenwood, N. Mex. (09444000), streamgage; and the San Francisco River near Clifton, Ariz. (09444500), streamgage (fig. 10). Monthly streamflow values for these streamgages are presented in appendix 9. Mean annual streamflow was 15,815 acre-ft at the San Francisco River near Reserve, N. Mex. (09442680), streamgage; 73,010 acre-ft at the San Francisco River near Glenwood, N. Mex. (09444000), streamgage; and 162,288 acre-ft at the San Francisco at Clifton, Ariz. (09444500), streamgage (table 9). Annual flows at the San Francisco River near Reserve, N. Mex. (09442680), streamgage ranged from 3,290 acre-ft in 2004 to 56,240 acre-ft in 1993, at the San Francisco River near Glenwood, N. Mex. (09444000), streamgage ranged from 19,880 acre-ft in 2000 to 252,800 acre-ft in 1993, and at the San Francisco River near Clifton, Ariz. (09444500), streamgage ranged from 40,560 acre-ft in 2000 to 601,400 acre-ft in 1993 (fig. $12 A$; table 9). Departures from mean annual streamflow were strongly positive for 1985, 1991-93, 1995, and 2005 but were near zero or negative for the remainder of the study period (fig. 12B).

\section{San Francisco River Basin Gains and Losses}

Reach SF-1 (fig. 10) was a gaining reach for the study period (fig. 12C; table 9). Over the study period, gains for reach SF-1 ranged from 14,450 acre-ft in 2011 to 196,560 acre-ft in 1993. Reach SF-2 (fig. 10) was also a gaining reach, with gains ranging from 20,680 acre-ft in 2000 to 348,600 acre-ft in 1993. The San Francisco River does not have inflow to the State since it originates in New Mexico (fig. 10). Gain/ loss was not computed for the entirety of the stream, but the San Francisco River contributed a mean annual outflow of 162,288 acre-ft and a total outflow of 4,706,360 acre-ft over the study period (table 2). Annual outflows to Arizona ranged from 40,560 acre-ft in 2000 to 601,400 acre-ft in 1993. 


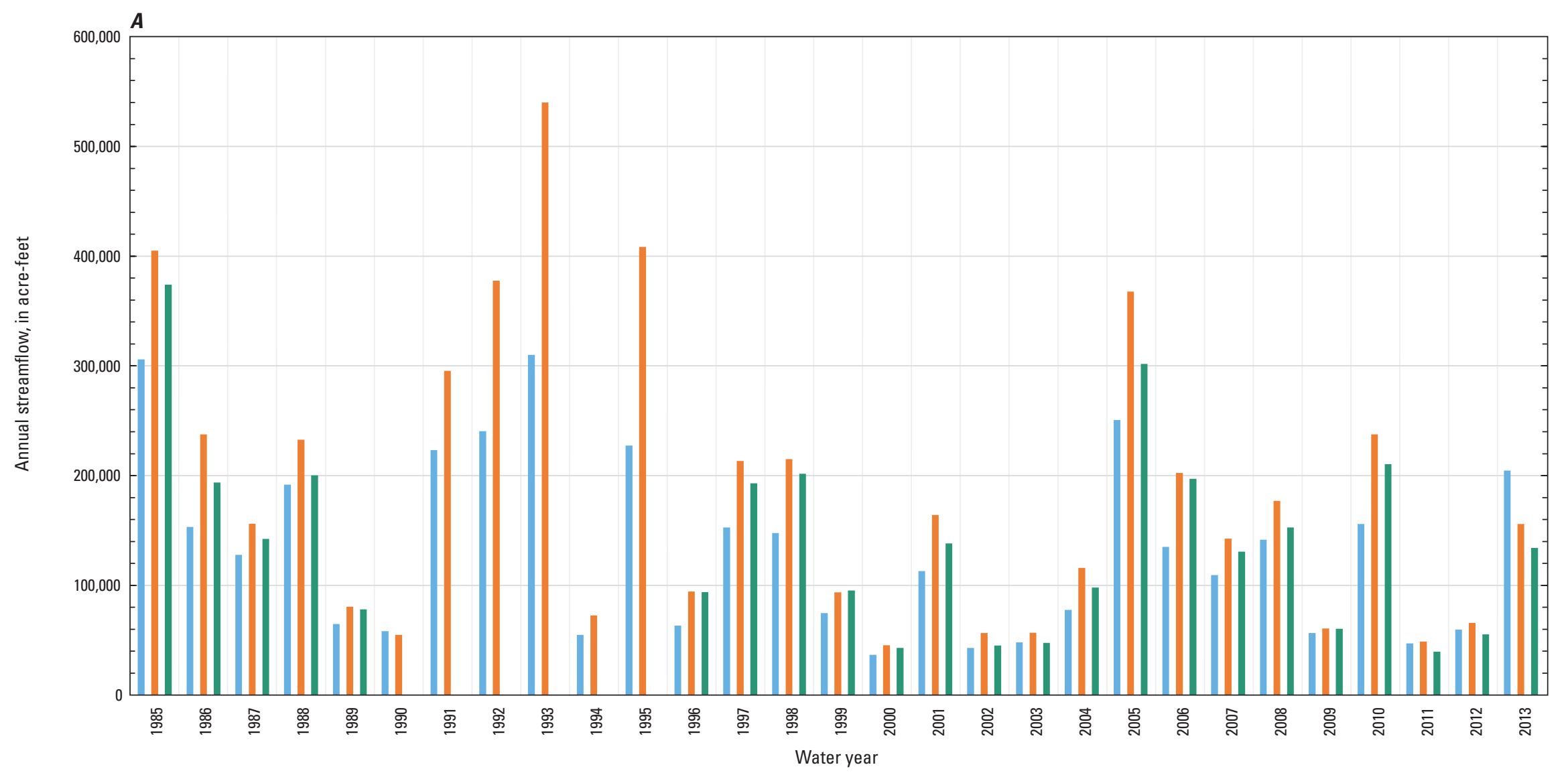

EXPLANATION

Streamgage (station identification number)

- Gila River near Gila, N. Mex. (09430500)—No data for 1990-95

- Gila River below Blue Creek, near Virden, N.Mex. (09432000)

- Gila River near Clifton, Ariz. (09442000)

Figure 11. Annual streamflow, departure from mean annual streamflow, and annual difference in streamflow for streams in the Gila River Basin in the six-basin study area, New Mexico and parts of bordering States and Mexico, water years 1985-2013.

$A$, Gila River Basin annual streamflow by streamgage, in downstream order 


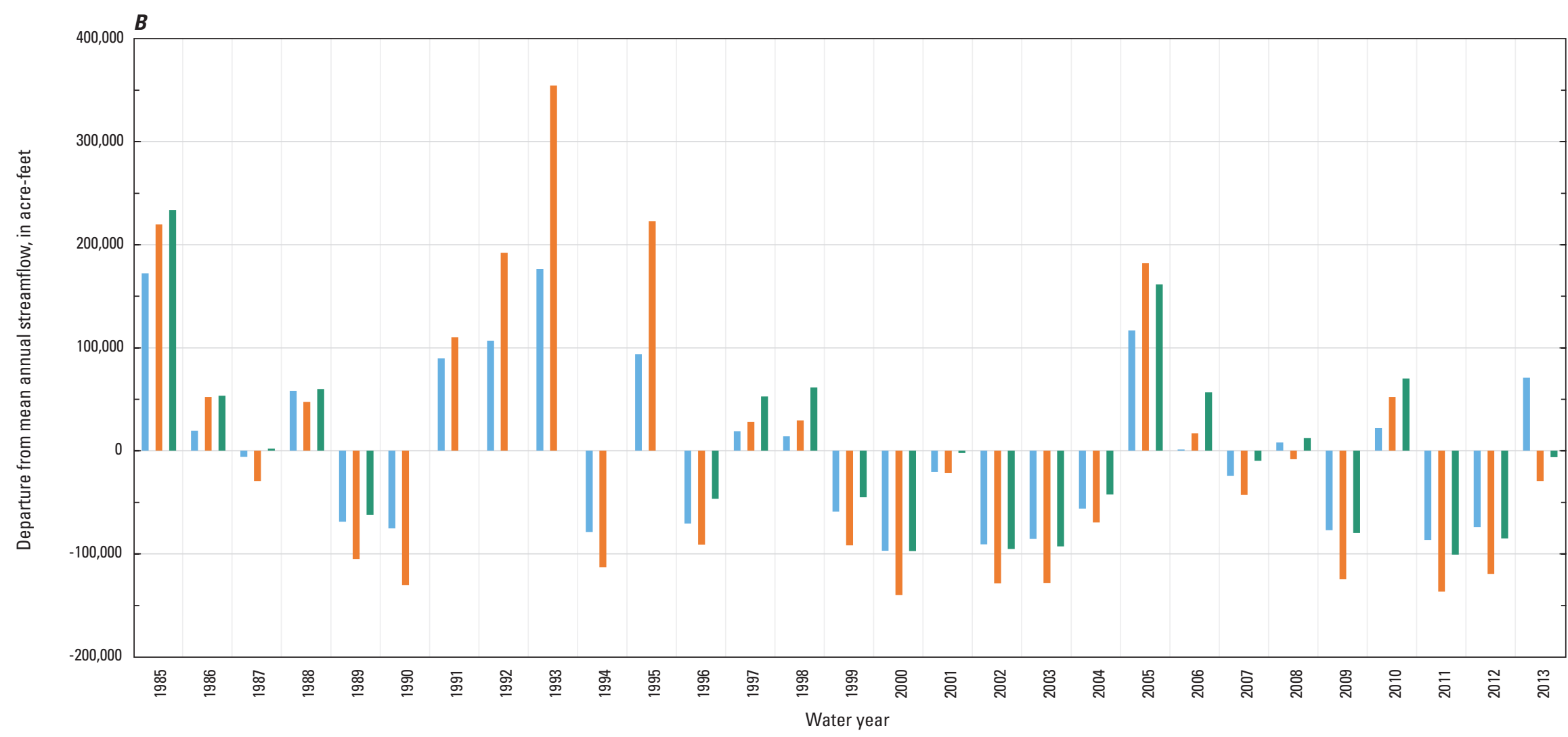

EXPLANATION

\section{Streamgage (station identification number)}

- Gila River near Gila, N. Mex. (09430500)—No data for 1990-95

- Gila River below Blue Creek, near Virden, N. Mex. (09432000)

- Gila River near Clifton, Ariz. (09442000)

Figure 11. Annual streamflow, departure from mean annual streamflow, and annual difference in streamflow for streams in the Gila River Basin in the six-basin study area, New Mexico and parts of bordering States and Mexico, water years 1985-2013.-Continued

$B$, Departure of annual streamflow from mean annual streamflow at Gila River streamgages. 


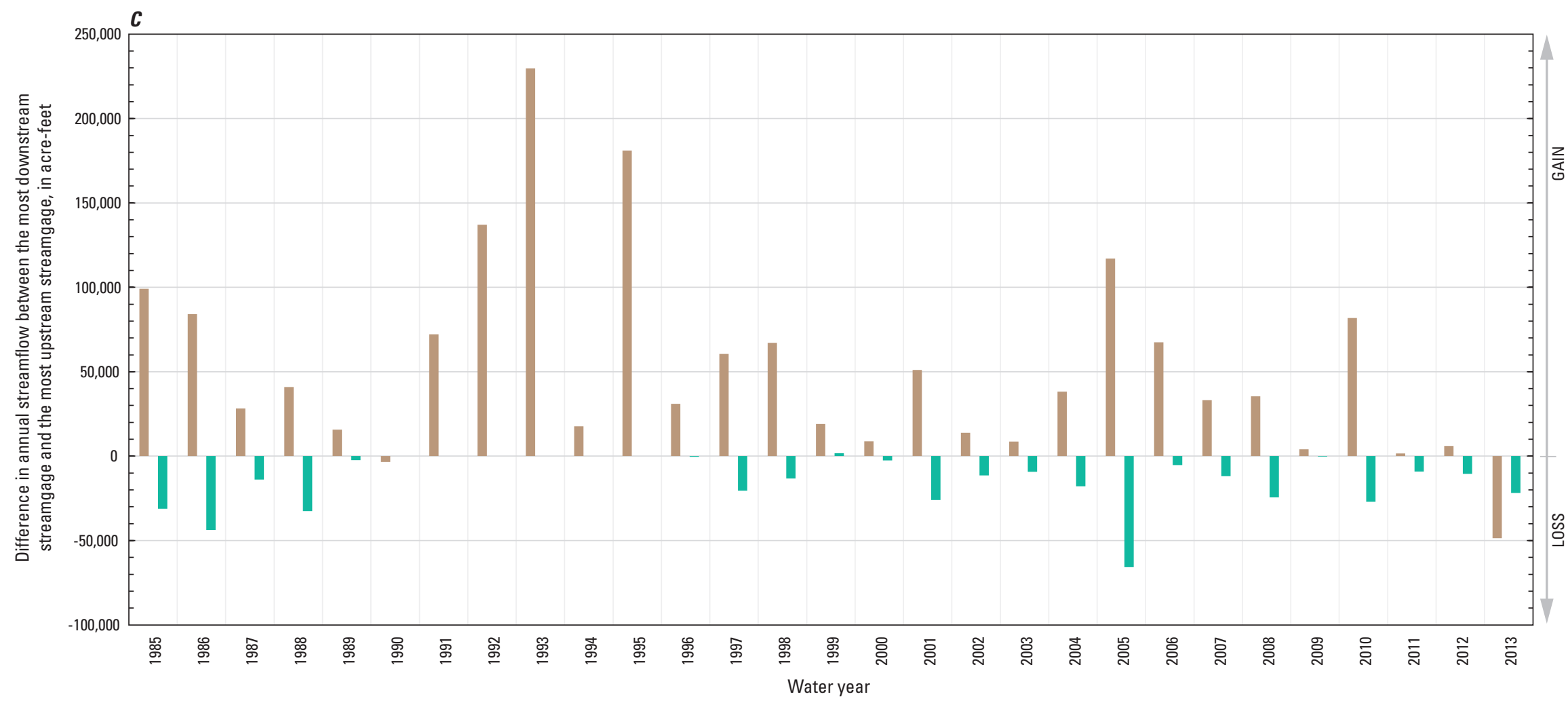

\section{EXPLANATION}

Gila River (GIL) reach number (annual difference in streamflow) -

Positive average values indicate a gain over that reach;

negative average values indicate a loss over that reach

- GIL-1 (average $+51,677$ acre-feet)

— GIL-2 (average -17,344 acre-feet)—No data for 1990-95

Figure 11. Annual streamflow, departure from mean annual streamflow, and annual difference in streamflow for streams in the Gila River Basin in the six-basin study area, New Mexico and parts of bordering States and Mexico, water years 1985-2013.-Continued

$C$, Gila River Basin annual difference in streamflow by reach. 
Table 9. Annual streamflow and annual difference in streamflow by reach for selected San Francisco River Basin streamgages in the six-basin study area, New Mexico and parts of bordering States and Mexico, water years 1985-2013.

[N. Mex., New Mexico; acre-ft, acre-feet; Ariz., Arizona; SF, San Francisco River reach, numbered in downstream order]

\begin{tabular}{|c|c|c|c|c|c|}
\hline \multicolumn{4}{|c|}{ Annual streamflow } & \multicolumn{2}{|c|}{ Annual difference in streamflow by reach } \\
\hline & & & & SF-1 & SF-2 \\
\hline $\begin{array}{l}\text { Water } \\
\text { year }\end{array}$ & $\begin{array}{c}09442680 \\
\text { San Francisco River } \\
\text { near Reserve, N. Mex. } \\
\text { (acre-ft) }\end{array}$ & $\begin{array}{c}09444000 \\
\text { San Francisco River } \\
\text { near Glenwood, N. Mex. } \\
\text { (acre-ft) }\end{array}$ & $\begin{array}{c}09444500 \\
\text { San Francisco River } \\
\text { at Clifton, Ariz. } \\
\text { (acre-ft) }\end{array}$ & $\begin{array}{c}09442680 \text { San Francisco River } \\
\text { near Reserve, N. Mex., to } \\
09444000 \text { San Francisco River } \\
\text { near Glenwood, N. Mex. } \\
\text { (acre-ft) }\end{array}$ & $\begin{array}{c}09444000 \text { San Francisco River } \\
\text { near Glenwood, N. Mex., to } \\
09444500 \text { San Francisco } \\
\text { River at Clifton, Ariz. } \\
\text { (acre-ft) }\end{array}$ \\
\hline 1985 & 51,790 & 209,700 & 372,600 & 157,910 & 162,900 \\
\hline 1986 & 11,740 & 60,660 & 139,900 & 48,920 & 79,240 \\
\hline 1987 & 40,270 & 109,500 & 198,400 & 69,230 & 88,900 \\
\hline 1988 & 25,640 & 95,670 & 193,700 & 70,030 & 98,030 \\
\hline 1989 & 9,200 & 33,580 & 70,630 & 24,380 & 37,050 \\
\hline 1990 & 4,940 & 21,120 & 51,510 & 16,180 & 30,390 \\
\hline 1991 & 19,740 & 129,400 & 274,400 & 109,660 & 145,000 \\
\hline 1992 & 31,420 & 139,500 & 345,900 & 108,080 & 206,400 \\
\hline 1993 & 56,240 & 252,800 & 601,400 & 196,560 & 348,600 \\
\hline 1994 & 7,160 & 32,680 & 65,960 & 25,520 & 33,280 \\
\hline 1995 & 24,160 & 123,500 & 301,300 & 99,340 & 177,800 \\
\hline 1996 & 4,310 & 22,530 & 65,700 & 18,220 & 43,170 \\
\hline 1997 & 13,860 & 37,330 & 112,200 & 23,470 & 74,870 \\
\hline 1998 & 12,290 & 67,060 & 154,200 & 54,770 & 87,140 \\
\hline 1999 & 14,720 & 44,200 & 106,600 & 29,480 & 62,400 \\
\hline 2000 & 4,200 & 19,880 & 40,560 & 15,680 & 20,680 \\
\hline 2001 & 19,130 & 109,600 & 237,800 & 90,470 & 128,200 \\
\hline 2002 & 4,020 & 27,360 & 52,010 & 23,340 & 24,650 \\
\hline 2003 & 3,640 & 23,200 & 57,940 & 19,560 & 34,740 \\
\hline 2004 & 3,290 & 25,620 & 69,610 & 22,330 & 43,990 \\
\hline 2005 & 22,790 & 112,500 & 296,100 & 89,710 & 183,600 \\
\hline 2006 & 8,090 & 60,020 & 120,500 & 51,930 & 60,480 \\
\hline 2007 & 8,520 & 42,410 & 97,830 & 33,890 & 55,420 \\
\hline 2008 & 14,340 & 75,070 & 180,800 & 60,730 & 105,730 \\
\hline 2009 & 4,780 & 22,010 & 50,200 & 17,230 & 28,190 \\
\hline 2010 & 16,000 & 78,990 & 193,800 & 62,990 & 114,810 \\
\hline 2011 & 5,610 & 20,060 & 43,760 & 14,450 & 23,700 \\
\hline 2012 & 5,550 & 23,610 & 49,450 & 18,060 & 25,840 \\
\hline 2013 & 11,200 & 97,730 & 161,600 & 86,530 & 63,870 \\
\hline $\begin{array}{r}\text { Mean annual } \\
\text { streamflow }\end{array}$ & 15,815 & 73,010 & 162,288 & 57,195 & 89,278 \\
\hline
\end{tabular}




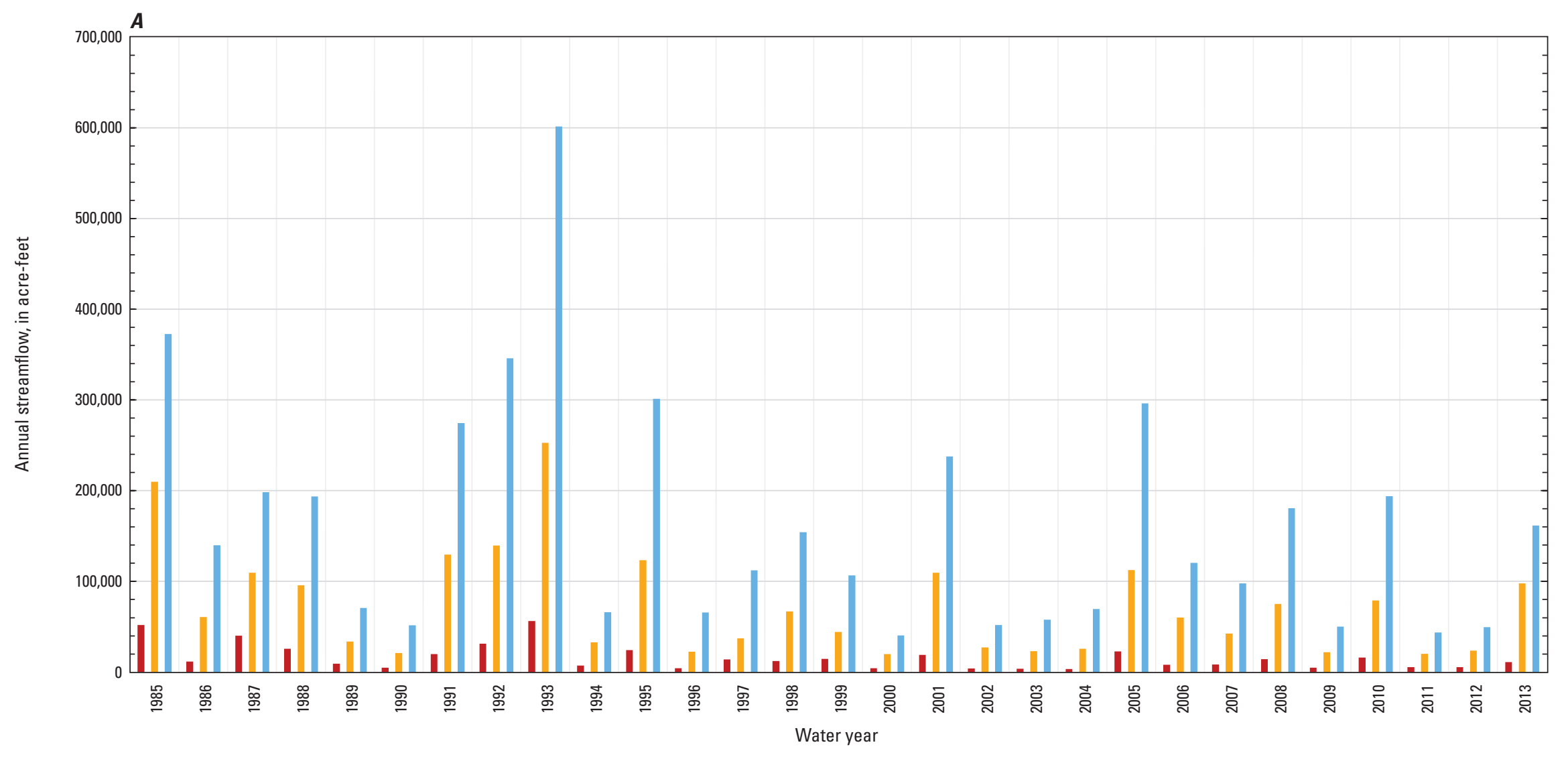

EXPLANATION

Streamgage (station identification number)

- San Francisco River near Reserve,

N. Mex. (09442680)

- San Francisco River near Glenwood

N. Mex. (09444000)

- San Francisco River at Clifton, Ariz.

(09444500)

Figure 12. Annual streamflow, departure from mean annual streamflow, and annual difference in streamflow for streams in the San Francisco River Basin in the six-basin study area, New Mexico and parts of bordering States and Mexico, water years 1985-2013.

$A$, San Francisco River Basin annual streamflow by streamgage, in downstream order 


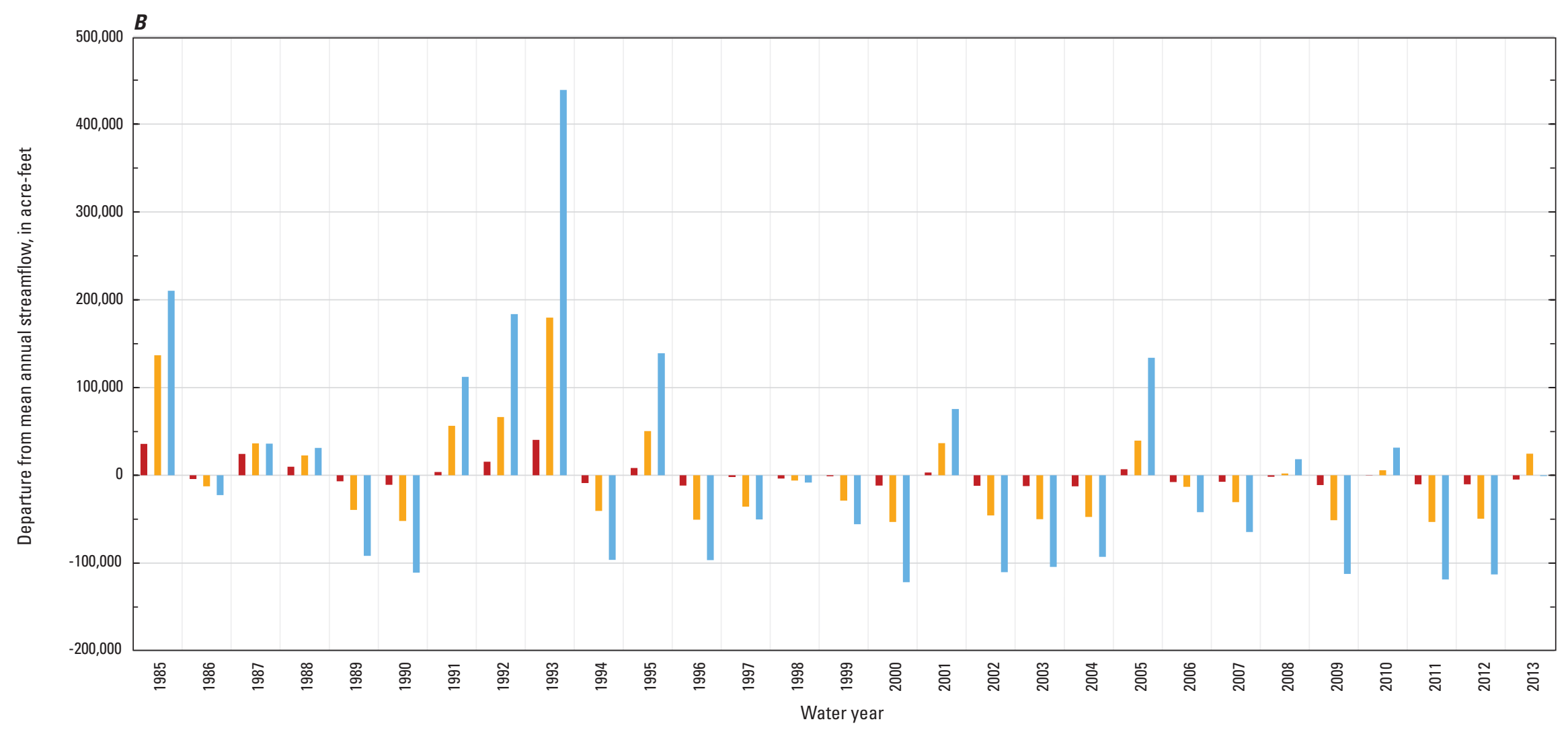

\section{EXPLANATION}

\section{Streamgage (station identification number)}

- San Francisco River near Reserve, N. Mex. (09442680)

- San Francisco River near Glenwood N. Mex. (09444000)

- San Francisco River at Clifton, Ariz. (09444500)

Figure 12. Annual streamflow, departure from mean annual streamflow, and annual difference in streamflow for streams in the San Francisco River Basin in the six-basin study area, New Mexico and parts of bordering States and Mexico, water years 1985-2013.-Continued 


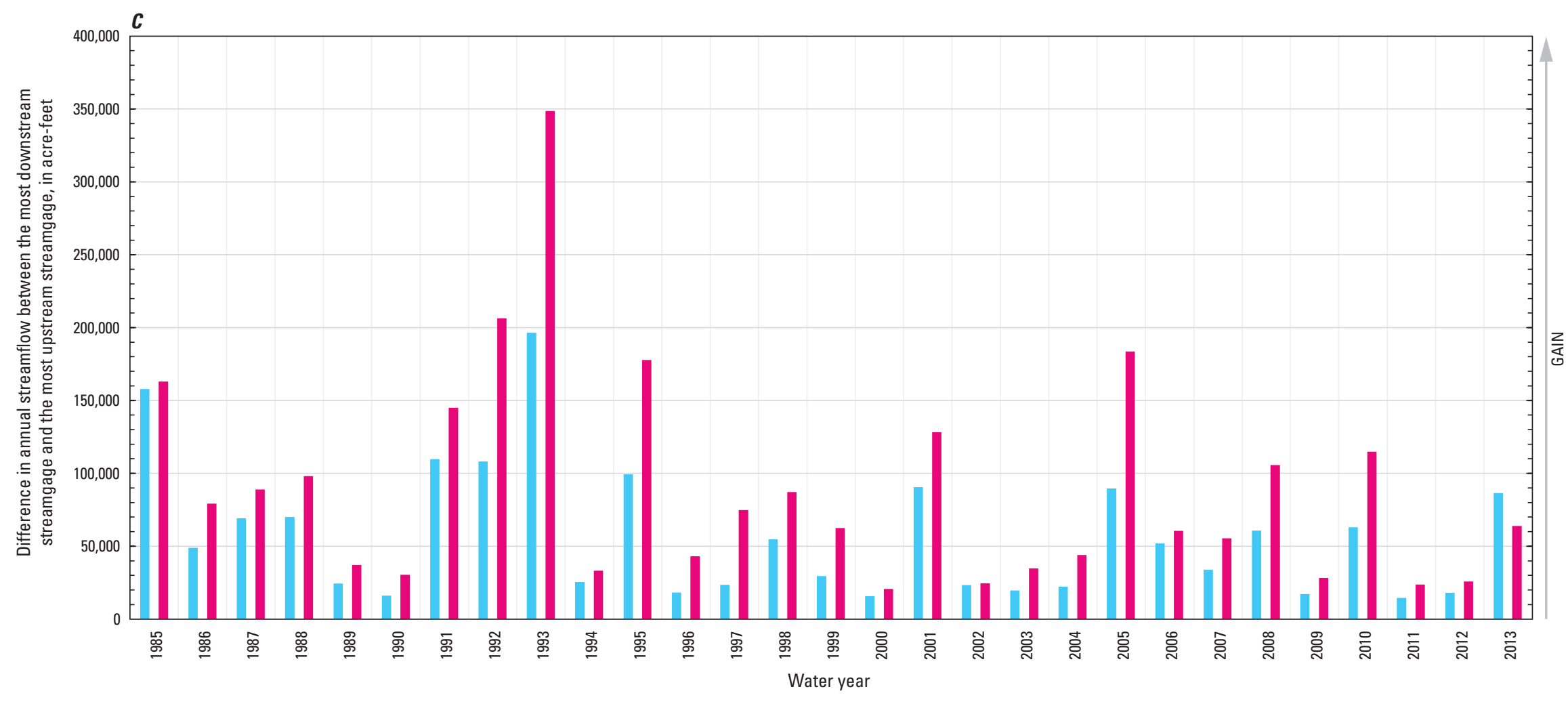

\section{EXPLANATION}

San Francisco River (SF) reach number (annual difference in streamflow)-Positive
average values indicate a gain over that reach

- SF-1 (average $+57,195$ acre-feet)

- SF-2 (average $+89,278$ acre-feet)

Figure 12. Annual streamflow, departure from mean annual streamflow, and annual difference in streamflow for streams in the San Francisco River Basin in the six-basin study area, New Mexico and parts of bordering States and Mexico, water years 1985-2013.-Continued

C, San Francisco River Basin annual difference in streamflow by reach. 


\section{Summary}

In 2014, the New Mexico Water Resources Research Institute began a statewide assessment of the water resources of New Mexico. The U.S. Geological Survey, in cooperation with the New Mexico Water Resources Research Institute, addressed the streamflow component of the assessment by examining streamgage data for major river basins and streams in New Mexico for the study period over water years 19852013 (all references to years in this report are to water years).

The annual inflow to and outflow from New Mexico generally decreased over the study period. The mean annual inflow over the study period was 746,718 acre-feet (acre-ft), and the mean annual outflow was 2,179,249 acre-ft.

In the Rio Grande Basin, increases in flow between the Costilla Creek below Costilla Dam, N. Mex. (08254000), streamgage and the Costilla Creek near Costilla, N. Mex. (08255500), streamgage indicate that there were substantial gains in flow between the two streamgages. The highest annual flows for the Rio Grande occurred in 1985-87, and except at the Rio Grande below Elephant Butte Dam, N. Mex. (08361000), streamgage and the Rio Grande at El Paso, Texas (08364000), streamgage the lowest flows occurred in 2002-03. Mean annual streamflows in the Rio Grande from 1985 to 2013 increased in magnitude in the downstream direction to a high of 1,042,055 acre-ft at the Rio Grande at Otowi Bridge, N. Mex. (08313000), streamgage but in general decreased downstream from this streamgage, reaching a low mean annual streamflow of 432,142 acre-ft at the Rio Grande at El Paso, Tex. (08364000), streamgage. For the Red River, Rio Hondo, and Rio Pueblo, departures from mean annual streamflow generally were positive for 1985-87, 1991-95, and 2008-09 and generally were negative during the rest of the study period.

Over the study period, annual flows in the Rio Chama generally increased downstream. For 1985-95, only 1988-90 had negative departures from mean annual streamflow. After 1995, negative departures from the mean annual streamflow became more frequent. The Rio Chama reaches were gaining in most years over the study period.

The Rio Puerco annual flows, at both streamgages, generally decreased after 2000. Annual flows at the Rio Puerco near Bernardo, N. Mex. (08353000), streamgage showed a greater decrease over the years than at the Rio Puerco above Arroyo Chico near Guadalupe, N. Mex. (08334000), streamgage but exhibited high annual flows in 2006 and 2013. Reach RP-1 was a gaining reach for 24 years of the study period.

In general, total annual streamflow on the Pecos River increased from 1985 to 1995 but decreased from 1995 to 2013. Departures from mean annual streamflow generally were positive for 1985-2000 and negative for 2001-13. The greatest gain on the Pecos River was estimated at reach PEC-5, which had gains in all 29 years and had the greatest mean annual gain, 64,821 acre-ft. Reach PEC-9 had losses in all 29 years and had the greatest mean annual loss for the study period, 105,583 acre-ft. The Pecos River contributed a mean annual outflow of 73,819 acre-ft and a total outflow of 2,140,740 acre-ft from 1985 to 2013.

For the Rio Hondo, low annual streamflows generally occurred in 1999-2004, 2009, and 2011-12. The highest annual streamflow at all streamgages occurred in 1987. Annual streamflows have generally decreased in magnitude since 1992, but there were moderate flows at some locations during 2006-13. Reach RH-1 was a losing reach for 16 years of the study, with annual gains early in the study period. The magnitude of the gains decreased over time, and reach RH-1 ultimately became a losing reach with periodic gaining years. Reach RH-2 was a losing reach for 28 years over the study period.

Over the study period, the San Juan River had some of the highest flows of any river in New Mexico, and flow on the river generally increased in the downstream direction. Departures from mean annual streamflow were positive from 1985 to 1987 and peaked in 1987. From 2000 to 2013, departures from the mean annual streamflow were predominantly negative; positive departures occurred for some or all of the San Juan River streamgages in 2001, 2005, 2007, and 2008.

Streamflow at the Animas River streamgages was highly variable from year to year but after 1999, generally, tended to decrease. Over the study period, reach ANI-1 generally was a losing reach except for 1987 and 1997. Annual flows at the La Plata River near Farmington, N. Mex. (09367500), streamgage generally were less than the annual inflow to the State at the La Plata River at Colorado-New Mexico State line (09366500) streamgage. Departures from mean annual streamflow in the La Plata River were positive from 1985 to 1987 but decreased to just above average flows in 1998. After 1987, departures from mean annual streamflow were close to zero, except for 1993. Over the study period, reach PLA-1 generally was a losing reach except for 1986, 1987, and 1993.

Prior to 1999, departures from mean annual streamflow at Canadian River streamgages were variable, but after 1999, departures generally were negative. The lowest annual flows occurred in 2003, 2011, and 2012. Inflow from the Canadian River in Colorado for this report is assumed to be zero since the first Canadian River streamgage of the study is in New Mexico. Canadian River annual outflow from New Mexico ranged from a high of 104,800 acre-ft in 1999 to a low of 1,670 acre-ft in 1986. Over the study period, reach CAN-1 was a gaining reach for all 29 years, with gains above average from 1985 to 1999, but, in general, remained below average through 2013. Reach CAN-2 was a losing reach for all years except 2003. Losses were below the mean before 1999, but thereafter losses tended to be above the mean. The Canadian River contributed a mean annual outflow of 22,281 acre-ft and a total outflow of 646,160 acre-ft from 1985 to 2013.

Departures from mean annual streamflow for the Cimarron River were variable through 1999 but generally were negative through 2013. Over the study period, reach CIM-1 generally was a gaining reach except for 1996, 2002, 
2011, and 2013. There were 13 above average annual gains over the 29-year study period.

Departures from mean annual streamflow on the Gila River were variable from 1985 to 1998 and generally were negative thereafter, except for 2005-06 and 2010. Annual flows at the Gila River below Blue Creek, near Virden, N. Mex. (09432000), streamgage generally were higher than at the other two Gila River streamgages, except for 1990, 1999, and 2013. Over the study period, reach GIL-1 was a gaining reach for all years except 1990 and 2013, while reach GIL-2 was a losing reach for all years with data except 1999. The Gila River contributed a mean annual outflow of 140,302 acre-ft and a total outflow of 3,226,950 acre-ft over the study period.

Departures from mean annual streamflow on the San Francisco River were strongly positive for 1985, 1991-93, 1995, and 2005 but were near zero or negative for the remainder of the study period. Both reaches on the San Francisco River were gaining reaches. The San Francisco River contributed a mean annual outflow of 162,288 acre-ft and a total outflow of 4,706,360 acre-ft over the study period.

\section{References Cited}

Bartholoma, S.D., Kolva, J.R., and Nielsen, J.P., 2003, User's manual for the National Water Information System of the U.S. Geological Survey_-Automated Data Processing System (ADAPS): U.S. Geological Survey Open-File Report 03-123, 407 p., accessed June 9, 2015, at http:// pubs.usgs.gov/of/2003/ofr03123/.

Beal, L.V., and Gold, R.L., 1987a, Water resources data, New Mexico, water year 1986: U.S. Geological Survey WaterData Report NM-86-1, 454 p.

Beal, L.V., and Gold, R.L., 1987b, Water resources data, New Mexico, water year 1987: U.S. Geological Survey WaterData Report NM-87-1, 450 p.

Borland, J.P., and Beal, L.V., 1988, Water resources data, New Mexico, water year 1988: U.S. Geological Survey WaterData Report NM-88-1, 490 p.

Borland, J.P., Cruz, R.R., McCracken, R.L., Lepp, R.L., Ortiz, David, and Shaull, D.A., 1991, Water resources data, New Mexico, water year 1990: U.S. Geological Survey WaterData Report NM-90-1, 466 p.

Borland, J.P., DeWees, R.K., McCracken, R.L., Lepp, R.L., Ortiz, David, and Shaull, D.A., 1990, Water resources data, New Mexico, water year 1989: U.S. Geological Survey Water-Data Report NM-89-1, 426 p.

Borland, J.P., DeWees, R.K., McCracken, R.L., Lepp, R.L., Ortiz, David, and Shaull, D.A., 1992, Water resources data, New Mexico, water year 1991: U.S. Geological Survey Water-Data Report NM-91-1, 557 p.
Borland, J.P., and Ong, Kim, 1995, Water resources data, New Mexico, water year 1994: U.S. Geological Survey WaterData Report NM-94-1, 581 p.

Byrd, Dave, Allen, H.R., and Montaño, Mary, 2004, Water resources data, New Mexico, water year 2003: U.S. Geological Survey Water-Data Report NM-03-1, 437 p.

Byrd, Dave, Allen, H.R., and Montaño, Mary, 2005, Water resources data, New Mexico, water year 2004: U.S. Geological Survey Water-Data Report NM-04-1, 431 p.

Byrd, Dave, Lange, Kathy, and Beal, Linda, 2002, Water resources data, New Mexico, water year 2001: U.S. Geological Survey Water-Data Report NM-01-1, 403 p.

Byrd, Dave, Lange, Kathy, and Beal, Linda, 2003, Water resources data, New Mexico, water year 2002: U.S. Geological Survey Water-Data Report NM-02-1, 433 p.

Clow, D.W., 2010, Changes in timing of snowmelt and streamflow in Colorado-A response to recent warming: Journal of Climate, v. 23, p. 2293-2306.

Cruz, R.R., DeWees, R.K., Funderburg, D.E., Lepp, R.L., Ortiz, David, and Shaull, D.A., 1993, Water resources data, New Mexico, water year 1992: U.S. Geological Survey WaterData Report NM-92-1, 526 p.

Cruz, R.R., DeWees, R.K., Funderburg, D.E., Lepp, R.L., Ortiz, David, and Shaull, D.A., 1994, Water resources data, New Mexico, water year 1993: U.S. Geological Survey WaterData Report NM-93-1, 590 p.

Denis, L.P., Beal, L.V., and Allen, H.R., 1986, Water resources data, New Mexico, water year 1985: U.S. Geological Survey Water-Data Report NM-85-1, 482 p.

Dettinger, M.D., 2005, Changes in streamflow timing in the Western United States in recent decades: U.S. Geological Survey Fact Sheet 2005-3018, 4 p.

Hidalgo, H.G., Das, T., Dettinger, M.D., Cayan, D.R., Pierce, D.W., Barnett, T.P., Bala, G., Mirin, A., Wood, A.W., Bonfils, C., Santer, B.D., and Nozawa, T., 2009, Detection and attribution of streamflow timing changes to climate change in the Western United States: Journal of Climate, v. 22, p. 3838-3855.

Kelly, Susan, 2011, New Mexico's major reservoirs-An overview, in Water matters! A guide to water issues: Albuquerque, N. Mex., University of New Mexico School of Law, Utton Transboundary Resource Center, p. 19-1-1918, accessed April 1, 2015, at http://uttoncenter.unm.edu/ pdfs/water-matters-2014/19-new-mexico\%C2\%B9s-majorreservoirs--an-overview.pdf.

Kilpatrick, F.A., and Schneider, V.R., 1983, Use of flumes in measuring streamflow: U.S. Geological Survey Techniques of Water-Resources Investigations, book 3, chap. A14, 46 p. [Also available at http://pubs.usgs.gov/wsp/1732/report.pdf.] 
Levick, L., Fonseca, J., Goodrich, D., Hernandez, M., Semmens, D., Stromberg, J., Leidy, R., Scianni, M., Guertin, D.P., Tluczek, M., and Kepner, W., 2008, The ecological and hydrological significance of ephemeral and intermittent streams in the arid and semi-arid American Southwest: U.S. Environmental Protection Agency and U.S. Department of Agriculture Agricultural Research Service Southwest Watershed Research Center, EPA/600/R-08/134, ARS/233046, 116 p. [Also available at http://www.epa.gov/ esd/land-sci/pdf/EPHEMERAL_STREAMS_REPORT_ Final_508-Kepner.pdf.]

Lins, Harry, 2005, Streamflow trends in the United States: U.S. Geological Survey Fact Sheet 2005-3017, 4 p., accessed March 15, 2015, at http://pubs.er.usgs.gov/ publication/fs20053017.

Llewellyn, Dagmar, and Vaddey, Seshu, 2013, West-wide climate risk assessment-Upper Rio Grande impact assessment: Albuquerque, N. Mex., U.S. Bureau of Reclamation, Upper Colorado Region, p. 1-138.

Longworth, J.W., Valdez, J.M., Magnuson, M.L., Albury Sims, Elisa, and Keller, Jerry, 2008, New Mexico water use by categories 2005: New Mexico Office of the State Engineer, Technical Report v. 52, 111 p.

New Mexico Interstate Stream Commission, 2015, Interstate stream compacts: New Mexico Office of the State Engineer, accessed March 26, 2015, at http://www.ose.state.nm.us/ ISC/isc_compacts.php.

New Mexico Interstate Stream Commission and New Mexico Office of the State Engineer, 2002, Framework for public input to a State water plan-New Mexico water resource atlas: Santa Fe, New Mexico Office the State Engineer, 35 p., 20 pls.

New Mexico Water Resources Research Institute, [2014], 59th Annual New Mexico WRRI Water Conference: New Mexico Water Resources Research Institute, accessed March 15, 2015, at http://2014.wrri.nmsu.edu/.

Nolan, K.M., and Shields, R.R., 2000, Measurement of stream streamflow by wading: U.S. Geological Survey WaterResources Investigations Report 00-4036, CD-ROM.

Oberg, K.A., Morlock, S.E., and Caldwell, W.S., 2005, Quality assurance plan for streamflow measurements using acoustic Doppler current profilers: U.S. Geological Survey Scientific Investigation Report 2005-5183, 35 p. [Also available at http://pubs.usgs/sir/2005/5183/SIR_2005-5183.pdf.]

Ortiz, David, and Lange, K.M., 1996, Water resources data, New Mexico, water year 1995: U.S. Geological Survey Water-Data Report NM-95-1, 628 .

Ortiz, David, and Lange, K.M., 1997, Water resources data, New Mexico, water year 1996: U.S. Geological Survey Water-Data Report NM-96-1, 446 p.
Ortiz, David, Lange, Kathy, and Beal, Linda, 1998, Water resources data, New Mexico, water year 1997: U.S. Geological Survey Water-Data Report NM-97-1, 574 p.

Ortiz, David, Lange, Kathy, and Beal, Linda, 1999, Water resources data, New Mexico, water year 1998: U.S. Geological Survey Water-Data Report NM-98-1, 404 p.

Ortiz, David, Lange, Kathy, and Beal, Linda, 2000, Water resources data, New Mexico, water year 1999: U.S. Geological Survey Water-Data Report NM-99-1, 402 p.

Ortiz, David, Lange, Kathy, and Beal, Linda, 2001, Water resources data, New Mexico, water year 2000: U.S. Geological Survey Water-Data Report NM-00-1, 411 p.

Rantz, S.E., and others, 1982, Measurement and computation of streamflow, volume 1-Measurement of stage and streamflow: U.S. Geological Survey Water-Supply Paper 2175, 284 p. [Also available at http://pubs.usgs.gov/ of/1992/ofr92-144/.]

Stewart, I.T., Cayan, D.R., and Dettinger, M.D., 2004, Changes toward earlier streamflow timing across western North America: Journal of Climate, v. 18, p. 1136-1155.

Turnipseed, D.P., and Sauer, V.B., 2010, Streamflow measurements at gaging stations: U.S. Geological Survey Techniques and Methods, book 3, chap. A8, 87 p. [Also available at http://pubs.usgs.gov/tm/tm3-a8/.]

Waltemeyer, S.D., 1989, Statistical summaries of streamflow data in New Mexico through 1985: U.S. Geological Survey Water-Resources Investigations Report 88-4228, 204 p.

Waltemeyer, S.D., 1996, Analysis of the magnitude and frequency of peak streamflow and maximum observed peak streamflow in New Mexico: U.S. Geological Survey Scientific Investigations Report 96-4112, 79 p.

Waltemeyer, S.D., 2008, Analysis of the magnitude and frequency of peak streamflow and maximum observed peak streamflow in New Mexico and surrounding areas: U.S. Geological Survey Scientific Investigations Report 20085119, $105 \mathrm{p}$.
Publishing support provided by Lafayette Publishing Service Center 

